\title{
Ichthyo-diversity in the Anzali Wetland and its related rivers in the southern Caspian Sea basin, Iran
}

\author{
Keyvan Abbasi ${ }^{*}$, Mehdi Moradi ${ }^{1}$, Alireza Mirzajani ${ }^{1}$, Morteza Nikpour ${ }^{1}$, Yaghobali \\ Zahmatkesh $^{1}$, Asghar Abdoli ${ }^{2}$ and Hamed Mousavi-Sabet ${ }^{3,4}$ \\ ${ }^{1}$ Inland Waters Aquaculture Research Center, Iranian Fisheries Sciences Research Institute, Agricultural \\ Research, Education and Extension Organization, Bandar Anzali, Iran \\ ${ }^{2}$ Environmental Sciences Institute, Shahid Beheshti University, Tehran, Iran \\ ${ }^{3}$ Department of Fisheries, Faculty of Natural Resources, University of Guilan, Sowmeh-Sara, Iran \\ ${ }^{4}$ The Caspian Sea basin Research Center, University of Guilan, Rasht, Iran \\ *Corresponding author凶: keyvan_abbasi@yahoo.com
}

Received: 11 December 2019 Accepted: 26 December 2019 Published online: 31 December 2019

\begin{abstract}
The Anzali Wetland is one of the most important water bodies in Iran, due to the Caspian migratory fish spawning, located in the southern Caspian Sea basin, Iran. During a long-term monitoring program, between 1994 to 2019, identification and distribution of fish species were surveyed in five different locations inside the Anzali Wetland and eleven related rivers in its catchment area. In this study 72 fish species were recognized belonging to 17 orders, 21 families and 53 genera, including 66 species in the wetland and 53 species in the rivers. Among the 72 identified species, 34 species were resident in freshwater, 9 species were anadromous, 9 species live in estuarine and the others exist in different habitats. These species include 4 endemic species, 50 native species and 18 exotic species to Iranian waters. The number of species in different locations inside the Anzali Wetland was comparatively similar while it had high variation in different rivers. Twenty fish species are new records for the Anzali Wetland basin, including 10 estuarine, 5 ornamental, 2 riverine, one anadromous, one euryhaline and a small exotic fish.
\end{abstract}

Key words: Biodiversity, ichthyo-fauna, distribution, endemic, exotic, Anzali Wetland

\section{Introduction}

The Anzali Wetland located in Guilan Province, is located in the western part of the southern Caspian Sea, northern Iran. It consists of four main sections: Siahkeshim (southern part), Sheijan (eastern part), Sorkhankol (central part) and Abkenar (western part) (Fig. 1C). It covers an area of 19100 ha and is $22 \mathrm{~km}$ long and 2-4 km in width (Naderi et al., 2017).

The Anzali Wetland, is the most important freshwater ecosystem in the southern Caspian Sea basin, is confronted with many problems and negative impacts (Mirzajani, 2009), and is listed in the Montreux record as a priority site for conservation (Naderi et al., 2017). It acts as an Ecotone between different ecosystems: terrestrial, the Caspian Sea, brackish and freshwater environments (Kimbal and Kimbal, 1974).

Under the Department of Environment conservation management program, there is one protected area (Siahkeshim) and three wildlife refuges (Sorkhankol, Chokam, and Selkeh). 
Eleven rivers flow into the wetland, while five canals discharge the water directly to the Caspian Sea (Naderi et al., 2017).

The Anzali Wetland is under severe stress, with such impacts as sedimentation, eutrophication, different types of contaminants, overgrowth of aquatic vegetation and the invasion of exotic species; particularly in the last decades (Mirzajani, 2009; Mirzajani et al., 2010).

Today, most areas of the Anzali Wetland have been drained and degraded to shallow marshes, seasonally flooded grasslands and only the western part is distinguished by a large and shallow freshwater habitat (Mirzajani et al., 2010).

The Anzali Wetland is an important habitat for fisheries activity. According to an FAO report (Hydrorybproject, 1965), from the beginning of the 1960s, it was important both as a source of fishes and as the spawning ground of especially anadromous fish species. According to the statistics, the fish catches from 1932 to 1940 varied from 3100 to 5700 metric tons and at that time contributed $70 \%$ of the total Iranian catch of fish in Guilan Province (Hydrorybproject, 1965).

The major fish species in the catch were the anadromous Kutum, Rutilus kutum Kamenskii, 1901; Pike-perch, Sander lucioperca (Linnaeus, 1758), and Bream, Abramis brama (Linnaeus, 1758), which enter the wetland in autumn or in spring and spawn there. By the beginning of the 1960s, the total catch from the Anzali Wetland was only 100 metric tons, i.e., slightly less than $2 \%$ of the original catch (Holcik and Oláh, 1992).

Regarding the ichthyo-diversity of wetland, the first ichthyological investigation was by Holcik and Oláh (1992) and they reported 41 species from the Anzali Wetland and then Karimpour (1998) added one other species to the species list. After that, Abbasi et al. (1999) identified 49 species from the Anzali Wetland and its catchment area.

The present study is a review of the distribution and diversity of fishes in different parts of the Anzali Wetland and its related rivers, based on comprehensive fieldwork by the authors during the past 25 years.

\section{Material and Methods}

The sampling was carried out during different times and seasons over the years 1994 to 2019 . All parts of the Anzali Wetland have been collected, including Abkenar, Sheijan, Sorkhankol, Siahkeshim and the estuary (Fig. 1). Furthermore, all eleven rivers (NGO-IRAN, 2003) including Chafroud, Bahambar, Morghak, Khalkai, Palangvar, Masooleh-Roudkhan, Siahdarvishan, Pasikhan, Pirbazar (Siahroud), Tashroud and Sheijanroud (Fig. 1; Appendix 1) were collected. Different habitats in each part of the wetland and three sections of each river, including upper, middle and downstream were sampled (see figures in the Appendix 1).

Different sampling methods were used including cast net, haul seine, gill net, electro-fisher, hand line, dip net and handle nets. Also, some rare species which were caught by local fishermen were included in the studied samples.

A few specimens of each species were subsampled randomly and any others released. General characteristics such as color of the body and fins were documented by taking photographs. The collected individuals were fixed in $10 \%$ formalin solution after a natural death or anesthesia in a solution of $0.01 \%$ clove. The fixed specimens were transferred to the ichthyological laboratories (Inland Waters Aquaculture Research Center and University of Guilan) for further analysis. 
Fish identification followed Holcik (1989) and Kottelat and Freyhof (2007) using descriptive characteristics (the number of dorsal fins, type of mouth and caudal fin, oral and pharyngeal teeth, sensory organs on the head and number of barbs), meristic counts (the number of branched and unbranched rays of dorsal, pectoral, anal and caudal fins, the number of gill rakers and branchiostegal rays, lateral line scales), morphometric measurements (length and height of fins, distance between fin origins, length of head sections) and anatomical features (stomach form, the number and form of pyloric caeca, type of swim bladder and color of peritoneum).

Fish classification to family followed Nelson (1994; 2006) and Nelson et al. (2016) and determination to genus and species followed identification keys provided by different authors (Berg, 1948; 1949a, b; Svetovidov, 1952; Kazancheev, 1981; Abbasi et al., 1999; Abdoli, 2000; Naderi and Abdoli, 2004; Coad, 2005; 2010; Kottelat and Freyhof, 2007; Abdoli and Naderi, 2009; Mousavi-Sabet et al., 2015; Vasil'eva et al., 2015; Keivany et al., 2016; Abbasi, 2017; Eagderi et al., 2017; Jouladeh-Roudbar et al., 2017; Froese and Pauly, 2019).

Finally, the scientific name of each identified fish was checked against the last checklist of freshwater fishes of Iran (Esmaeili et al., 2018) and the catalogue of fishes (Fricke et al., 2019).
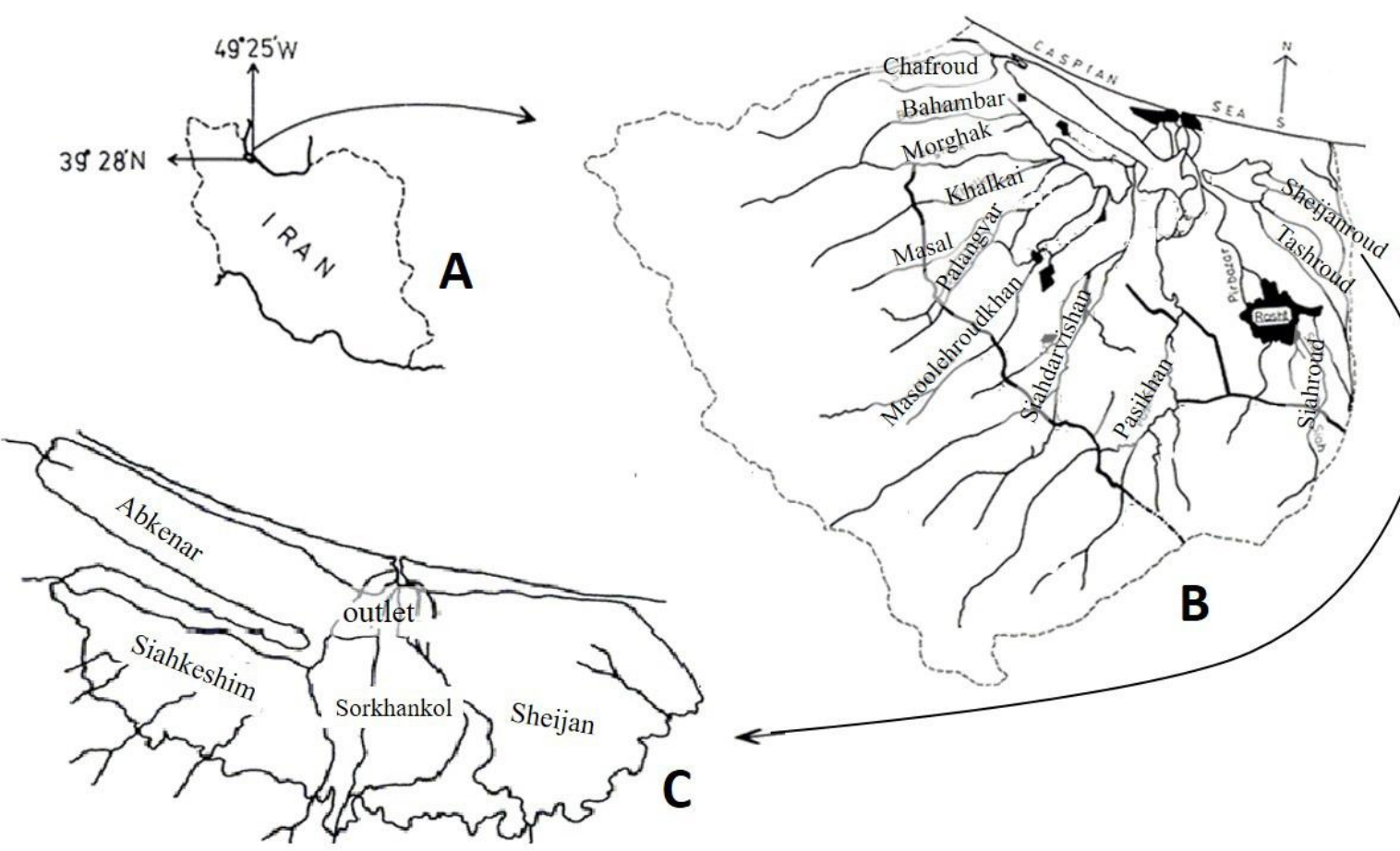

Figure 1: The studied area: Geographical point of the Anzali Wetland (A), catchment area with the main inlet rivers (B) and the different parts of the Anzali Wetland water body (C).

\section{Results}

The long-term ichthyological monitoring (1994-2019) confirmed the presence of 72 fish species in the Anzali Wetland and its catchment area. The fish belong to two classes the Petromyzontida, including Caspiomyzon wagneri (Kessler, 1870), and Actinopterygii (the other 71 species), 17 orders, 21 families and 53 genera. Eighteen families were recognized inside the wetland while nineteen families were present in the studied rivers (Table 1). 
Among the families, the Cyprinidae, Gobiidae and Clupeidae had the most diversity with 28, 13 and 4 species, respectively, while eleven families were recognized with only one representative (Table 1).

In total 66 species were identified inside the Anzali Wetland and in the adjacent estuary. Five exotic ornamental species, namely Channa micropeltes (Cuvier, 1831), Pangasius sanitwongsei Smith, 1931, Hypostomus plecostomus (Linnaeus, 1758), Piaractus brachypomus (Cuvier, 1818) and Poecilia reticulata Peters, 1859 were occasionally observed inside the wetland (Table 1; Appendix 2).

The number of fish species was approximately equal in different parts of the Anzali Wetland, except for the western part (Fig. 2). The most common species inside the wetland were from the cyprinids, followed by the gobiids (Fig. 3).

In the studied rivers 53 species were identified, of which only 6 species were not also observed inside the wetland and estuary; including the Caspian anadromous fishes, Acipenser persicus Borodin, 1897, Acipenser stellatus Pallas, 1771, and freshwater species, Barbus cyri De Filippi, 1865, Oxynoemacheilus bergianus (Derzhavin, 1934), Oncorhynchus mykiss (Walbaum, 1792) and Salmo trutta Linnaeus, 1758 (Table 1; Appendix 2).

Table 1: Distribution and ecological characteristics of identified fish species in the Anzali Wetland basin. En: Endemic, N: Native, A: Alien, Or: Ornamental, W: Western, S: Southern, C: Central, E: Eastern and O: Outlet (Estuary). Rivers: 1. Chafroud, 2. Bahambar, 3. Morghak, 4. Khalkai, 5. Palangvar, 6. Masoolehroudkhan, 7. Siahdarvishan, 8. Pasikhan, 9. Pirbazar, 10. Tashroud and 11. Sheijanroud.

\begin{tabular}{|c|c|c|c|c|c|c|c|}
\hline$\stackrel{\grave{c}}{0}$ & 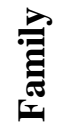 & Scientific name & Common name & Origin & $\begin{array}{l}\text { Wetland } \\
\text { areas }\end{array}$ & Rivers & $\begin{array}{l}\text { Ecological } \\
\text { group }\end{array}$ \\
\hline 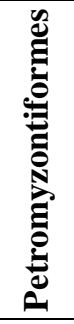 & 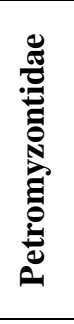 & $\begin{array}{l}\text { Caspiomyzon wagneri } \\
\text { (Kessler, 1870) }\end{array}$ & Caspian lamprey & $\mathrm{N}$ & WE & $4-8$ & G-II \\
\hline$\stackrel{\mathscr{E}}{\stackrel{\mathscr{E}}{0}}$ & 莺 & $\begin{array}{l}\text { Acipenser persicus } \\
\text { Borodin, } 1897\end{array}$ & Persian sturgeon & $\mathrm{N}$ & & 7 & G-II \\
\hline 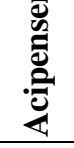 & $\frac{2}{2}$ & $\begin{array}{l}\text { Acipenser stellatus } \\
\quad \text { Pallas, } 1771\end{array}$ & Stellate sturgeon & $\mathrm{N}$ & & $5,7,8$ & G-II \\
\hline 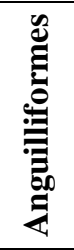 & 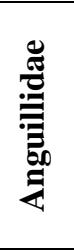 & $\begin{array}{c}\text { Anguilla anguilla } \\
\text { (Linnaeus, 1758) }\end{array}$ & European eel & $\mathrm{N}$ & $\mathrm{O}$ & & G-IV \\
\hline$\stackrel{\mathscr{E}}{\mathscr{E}}$ & : & $\begin{array}{l}\text { Alosa braschnikowi } \\
\text { (Borodin, 1904) }\end{array}$ & Caspian marine shad & $\mathrm{N}$ & $\mathrm{O}$ & & G-IV \\
\hline 节 & $\stackrel{\tilde{E}}{\tilde{U}}$ & $\begin{array}{c}\text { Alosa caspia } \\
\text { (Eichwald, 1838) }\end{array}$ & Caspian shad & $\mathrm{N}$ & WCEO & 7 & G-VI \\
\hline
\end{tabular}


Table 1. (Continued)
$\stackrel{0}{0}$
育 Scientific name
Common name
Origin
Wetland Rivers
Ecological
group

\begin{tabular}{|c|c|c|c|c|c|c|c|}
\hline 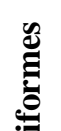 & $\frac{\mathscr{E}}{\mathscr{t}}$ & $\begin{array}{l}\text { Alosa kessleri } \\
\text { (Grimm, 1887) }\end{array}$ & $\begin{array}{c}\text { Caspian } \\
\text { anadromous } \\
\text { shad }\end{array}$ & $\mathrm{N}$ & EO & & G-V \\
\hline$\stackrel{\Xi}{\Xi}$ & $\bar{\Xi}$ & $\begin{array}{c}\text { Clupeonella caspia } \\
\text { Svetovidov, } 1941\end{array}$ & Caspian tyulka & $\mathrm{N}$ & WSCEO & 5,7 & G-VI \\
\hline \multirow{13}{*}{ 苞 } & \multirow{13}{*}{ 节 } & $\begin{array}{l}\text { Abramis brama } \\
\text { (Linnaeus, 1758) }\end{array}$ & Common bream & $\mathrm{N}$ & WSCEO & $\begin{array}{c}2,4,5,7- \\
9\end{array}$ & G-III \\
\hline & & $\begin{array}{c}\text { Alburnoides samiii } \\
\text { Mousavi-Sabet, Vatandoust and } \\
\text { Doadrio, } 2015\end{array}$ & $\begin{array}{l}\text { Safidrud } \\
\text { spirlin }\end{array}$ & En & SCE & $1-11$ & G-I \\
\hline & & $\begin{array}{l}\text { Alburnus chalcoides } \\
\text { (Güldenstaedt, 1772) }\end{array}$ & $\begin{array}{l}\text { Caspian } \\
\text { shemaya }\end{array}$ & $\mathrm{N}$ & WSCEO & $1-11$ & G-II \\
\hline & & $\begin{array}{l}\text { Alburnus filippi } \\
\text { Kessler, } 1877\end{array}$ & Kura bleak & $\mathrm{N}$ & WSCE & $4-8$ & G-I \\
\hline & & $\begin{array}{c}\text { Alburnus hohenackeri } \\
\text { Kessler, } 1877\end{array}$ & $\begin{array}{c}\text { North } \\
\text { Caucasian bleak }\end{array}$ & $\mathrm{N}$ & WSCEO & $1,2,4-11$ & G-I \\
\hline & & $\begin{array}{c}\text { Barbus cyri } \\
\text { De Filippi, } 1865\end{array}$ & Kura barbel & $\mathrm{N}$ & & $1-4,6-9$ & G-I \\
\hline & & $\begin{array}{l}\text { Blicca bjoerkna } \\
\text { (Linnaeus, 1758) }\end{array}$ & Silver bream & $\mathrm{N}$ & WSCEO & $\begin{array}{c}2,4,5,7- \\
\quad 11\end{array}$ & G-I \\
\hline & & $\begin{array}{l}\text { Capoeta razii } \\
\text { Jouladeh-Roudbar, Eagderi, } \\
\text { Ghanavi and Doadrio, } 2017\end{array}$ & Caspian scraper & En & WSCO & $1-11$ & G-I \\
\hline & & $\begin{array}{l}\text { Carassius auratus } \\
\text { (Linnaeus, 1758) }\end{array}$ & Goldfish & A, Or & WSCE & $\begin{array}{c}2,4,5,7- \\
9\end{array}$ & G-I \\
\hline & & $\begin{array}{l}\text { Carassius gibelio } \\
\text { (Bloch, 1782) }\end{array}$ & Prussian carp & A & WSCEO & $1-11$ & G-I \\
\hline & & $\begin{array}{l}\text { Ctenopharyngodon idella } \\
\text { (Valenciennes, 1844) }\end{array}$ & Grass carp & A & WSCE & $2,7,8$ & G-I \\
\hline & & $\begin{array}{l}\text { Cyprinus carpio } \\
\text { Linnaeus, } 1758\end{array}$ & Common carp & $\mathrm{N}$ & WSCEO & $\begin{array}{l}2,4,5,7 \\
\quad 8,11\end{array}$ & G-III \\
\hline & & $\begin{array}{l}\text { Hemiculter leucisculus } \\
\text { (Basilewsky, 1855) }\end{array}$ & Sharpbelly & A & WSCEO & $1,2,5-11$ & G-I \\
\hline
\end{tabular}




\section{Table 1. (Continued)}

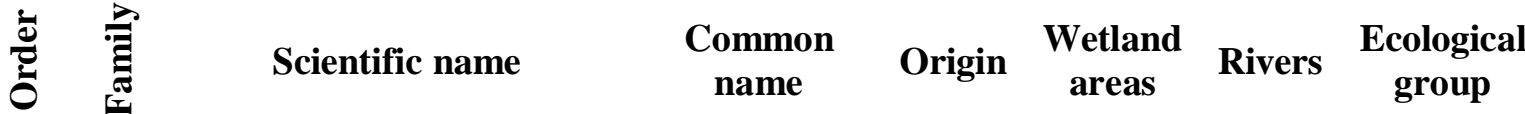

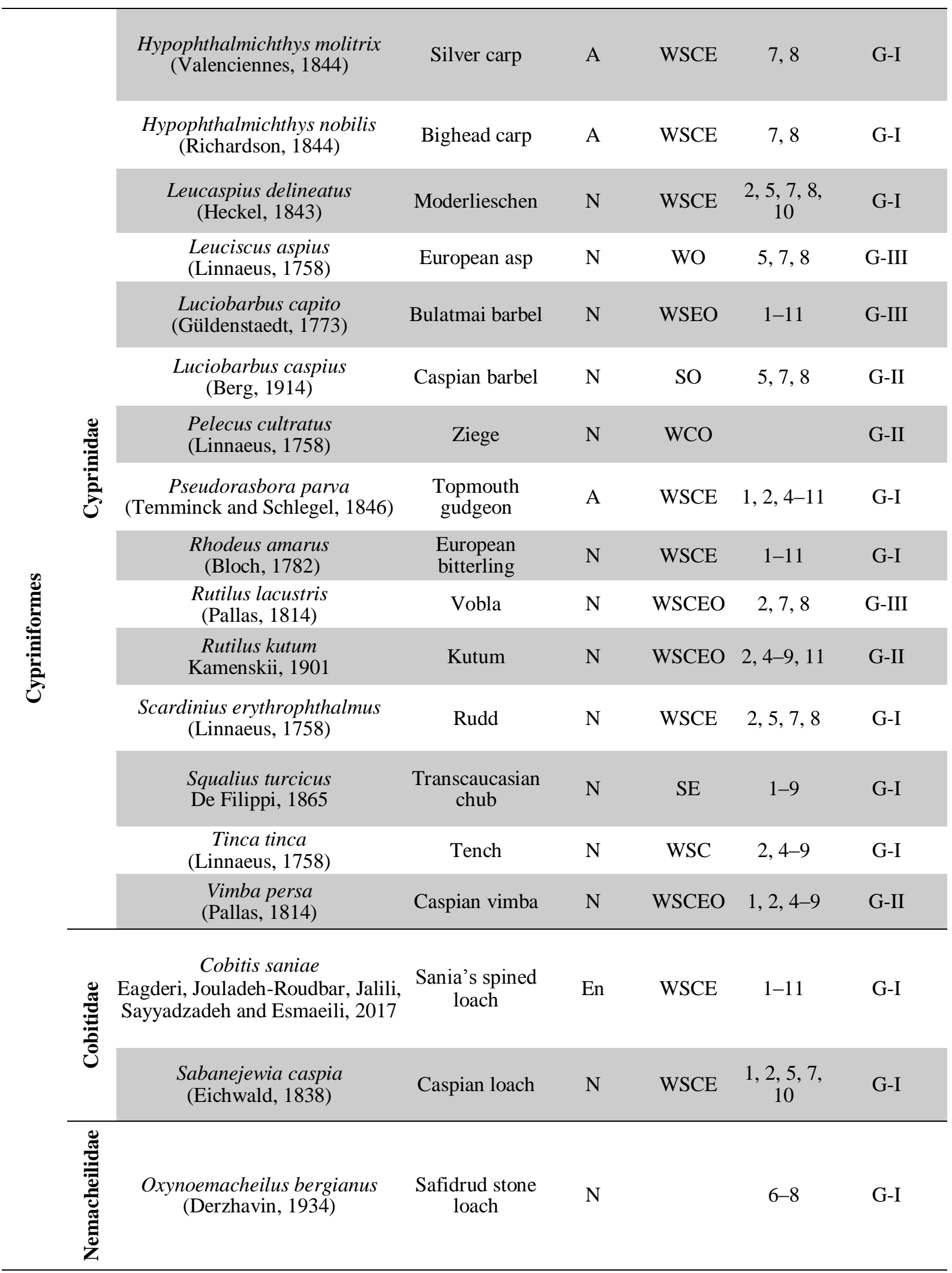




\section{Table 1. (Continued)}

\begin{tabular}{|c|c|c|c|c|c|c|c|}
\hline 矛 & $\underset{\Xi}{\nexists ٍ}$ & Scientific name & Common name & Origin & $\begin{array}{l}\text { Wetland } \\
\text { areas }\end{array}$ & Rivers & $\begin{array}{l}\text { Ecological } \\
\text { group }\end{array}$ \\
\hline 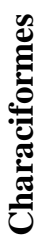 & 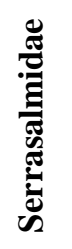 & $\begin{array}{l}\text { Piaractus brachypomus } \\
\text { (Cuvier, 1818) }\end{array}$ & Pirapitinga & A, Or & $\mathrm{E}, \mathrm{W}$ & & G-I \\
\hline \multirow{3}{*}{ 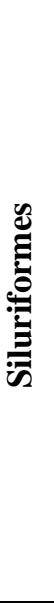 } & 营 & Silurus glanis Linnaeus, 1758 & Wels catfish & $\mathrm{N}$ & WSCEO & $2,4-8$ & G-I \\
\hline & 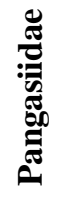 & $\begin{array}{l}\text { Pangasius sanitwongsei } \\
\text { Smith, } 1931\end{array}$ & Giant pangasius & A, Or & $\mathrm{E}, \mathrm{W}$ & 7 & G-I \\
\hline & 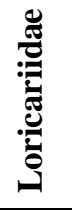 & $\begin{array}{l}\text { Hypostomus plecostomus } \\
\text { (Linnaeus, 1758) }\end{array}$ & $\begin{array}{l}\text { Suckermouth } \\
\text { catfish }\end{array}$ & A, Or & $\mathrm{E}, \mathrm{W}$ & 7 & G-I \\
\hline \multirow{3}{*}{ } & \multirow{3}{*}{ 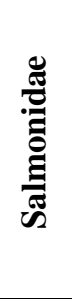 } & $\begin{array}{l}\text { Oncorhynchus mykiss } \\
\text { (Walbaum, 1792) }\end{array}$ & Rainbow trout & A & & $1,5-8$ & G-I \\
\hline & & $\begin{array}{l}\text { Salmo caspius } \\
\text { Kessler, } 1877\end{array}$ & Caspian trout & $\mathrm{N}$ & $\mathrm{W}, \mathrm{S}, \mathrm{O}$ & $4,5,7,8$ & G-II \\
\hline & & $\begin{array}{c}\text { Salmo trutta } \\
\text { Linnaeus, } 1758\end{array}$ & Brown trout & $\mathrm{N}$ & & $1,4-8$ & G-I \\
\hline 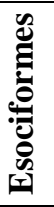 & 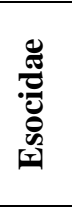 & $\begin{array}{c}\text { Esox lucius } \\
\text { Linnaeus, } 1758\end{array}$ & Northern pike & $\mathrm{N}$ & WSCEO & $\begin{array}{l}2,4-8 \\
10,11\end{array}$ & G-I \\
\hline \multirow{5}{*}{ 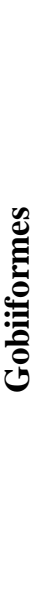 } & \multirow{5}{*}{ 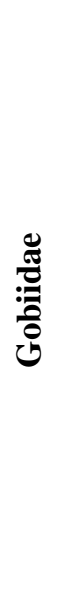 } & $\begin{array}{c}\text { Benthophilus ctenolepidus } \\
\text { Kessler, } 1877\end{array}$ & $\begin{array}{l}\text { Transparent } \\
\text { tadpole goby }\end{array}$ & $\mathrm{N}$ & $\mathrm{O}$ & & G-IV \\
\hline & & $\begin{array}{l}\text { Benthophilus leobergius } \\
\text { Berg, } 1949\end{array}$ & $\begin{array}{l}\text { Caspian stellate } \\
\text { tadpole goby }\end{array}$ & $\mathrm{N}$ & $\mathrm{O}$ & & G-IV \\
\hline & & $\begin{array}{c}\text { Knipowitschia caucasica } \\
\text { (Berg, 1916) }\end{array}$ & $\begin{array}{l}\text { Caucasian dwarf } \\
\text { goby }\end{array}$ & $\mathrm{N}$ & WSCEO & & $\mathrm{G}-\mathrm{V}$ \\
\hline & & $\begin{array}{l}\text { Neogobius caspius } \\
\text { (Eichwald, 1831) }\end{array}$ & Caspian goby & $\mathrm{N}$ & $\mathrm{O}$ & & G-IV \\
\hline & & $\begin{array}{l}\text { Neogobius melanostomus } \\
\text { (Pallas, 1814) }\end{array}$ & Round goby & $\mathrm{N}$ & WSEO & & $\mathrm{G}-\mathrm{V}$ \\
\hline
\end{tabular}




\section{Table 1. (Continued)}

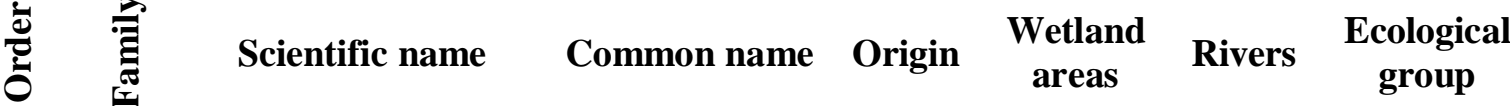

\begin{tabular}{|c|c|c|c|c|c|c|c|}
\hline \multirow{8}{*}{ 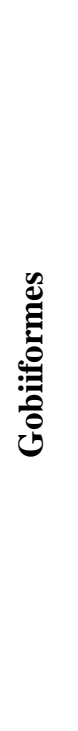 } & \multirow{8}{*}{ 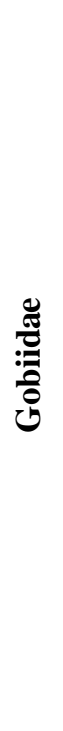 } & $\begin{array}{l}\text { Neogobius Pallasi } \\
\text { (Berg, 1916) }\end{array}$ & Caspian sand goby & $\mathrm{N}$ & $\mathrm{O}$ & & G-IV \\
\hline & & $\begin{array}{l}\text { Ponticola bathybius } \\
\text { (Kessler, 1877) }\end{array}$ & Deepwater Goby & $\mathrm{N}$ & $\mathrm{O}$ & & G-IV \\
\hline & & $\begin{array}{l}\text { Ponticola goebelii } \\
\text { (Kessler, 1874) }\end{array}$ & Ratan goby & $\mathrm{N}$ & WO & & G-V \\
\hline & & $\begin{array}{l}\text { Ponticola gorlap } \\
\text { (Iljin, 1949) }\end{array}$ & $\begin{array}{l}\text { Caspian bighead } \\
\text { goby }\end{array}$ & $\mathrm{N}$ & WSCEO & $1-11$ & G-VII \\
\hline & & $\begin{array}{c}\text { Ponticola iranicus } \\
\text { Vasil'eva, Mousavi-Sabet } \\
\text { and Vasil'ev, } 2015\end{array}$ & Persian goby & En & WSEO & $1-11$ & G-I \\
\hline & & $\begin{array}{l}\text { Ponticola syrman } \\
\text { (Nordmann, 1840) }\end{array}$ & Syrman goby & $\mathrm{N}$ & WO & & G-V \\
\hline & & $\begin{array}{l}\text { Proterorhinus nasalis } \\
\text { (De Filippi, 1863) }\end{array}$ & $\begin{array}{l}\text { Eastern tubenose } \\
\text { goby }\end{array}$ & $\mathrm{N}$ & WSCEO & $\begin{array}{l}1,2,7,10 \\
11\end{array}$ & G-VII \\
\hline & & $\begin{array}{c}\text { Rhinogobius lindbergi } \\
\text { Berg, } 1933\end{array}$ & Lake goby & A & WSCE & $\begin{array}{l}1,2,4,5 \\
\quad 7,8\end{array}$ & G-I \\
\hline \multirow{2}{*}{ 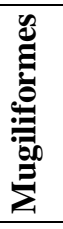 } & \multirow{2}{*}{ 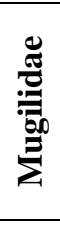 } & $\begin{array}{l}\text { Chelon auratus } \\
\text { (Risso, 1810) }\end{array}$ & Golden grey mullet & $\mathrm{A}$ & $\mathrm{O}$ & & G-IV \\
\hline & & $\begin{array}{l}\text { Chelon saliens } \\
\text { (Risso, 1810) }\end{array}$ & Leaping mullet & A & WCEO & 5,11 & $\mathrm{G}-\mathrm{V}$ \\
\hline 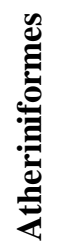 & 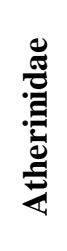 & $\begin{array}{l}\text { Atherina caspia } \\
\text { Eichwald, } 1831\end{array}$ & Caspian silverside & $\mathrm{N}$ & WCEO & 2,7 & G-VI \\
\hline \multirow{2}{*}{ 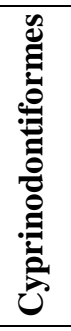 } & \multirow{2}{*}{ 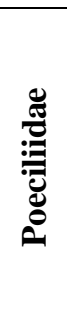 } & $\begin{array}{l}\text { Gambusia holbrooki } \\
\text { Girard, } 1859\end{array}$ & $\begin{array}{l}\text { Eastern } \\
\text { mosquitofish }\end{array}$ & A & WSCE & $1,2,4-11$ & G-I \\
\hline & & $\begin{array}{l}\text { Poecilia reticulata } \\
\quad \text { Peters, } 1859\end{array}$ & Guppy & A, Or & $\mathrm{C}$ & 7 & G-I \\
\hline 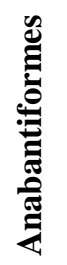 & & $\begin{array}{l}\text { Channa micropeltes } \\
\text { (Cuvier, 1831) }\end{array}$ & $\begin{array}{l}\text { Indonesian } \\
\text { snakehead }\end{array}$ & A, Or & $\mathrm{E}, \mathrm{W}$ & & G-I \\
\hline 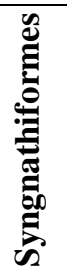 & 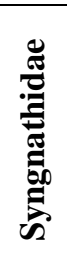 & $\begin{array}{l}\text { Syngnathus caspius } \\
\text { Eichwald, } 1831\end{array}$ & Caspian pipefish & $\mathrm{N}$ & WCO & & G-V \\
\hline
\end{tabular}


Table 1. (Continued)

\begin{tabular}{|c|c|c|c|c|c|c|c|}
\hline$\frac{\dot{0}}{0}$ & 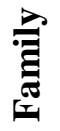 & Scientific name & Common name & Origin & $\begin{array}{l}\text { Wetland } \\
\text { areas }\end{array}$ & Rivers & $\begin{array}{c}\text { Ecological } \\
\text { group }\end{array}$ \\
\hline \multirow{3}{*}{ 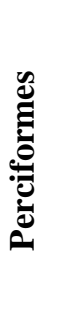 } & \multirow{3}{*}{ } & $\begin{array}{l}\text { Perca fluviatilis } \\
\text { Linnaeus, } 1758\end{array}$ & Perch & $\mathrm{N}$ & WSCEO & $2,5,7,8$ & G-I \\
\hline & & $\begin{array}{l}\text { Sander lucioperca } \\
\text { (Linnaeus, 1758) }\end{array}$ & Pike perch & $\mathrm{N}$ & WCEO & $2,5,7,8$ & G-III \\
\hline & & $\begin{array}{l}\text { Sander marinus } \\
\text { (Cuvier, 1828) }\end{array}$ & Estuarine perch & $\mathrm{N}$ & $\mathrm{O}$ & & G-IV \\
\hline \multirow{2}{*}{ 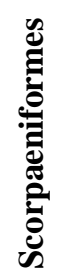 } & \multirow{2}{*}{ 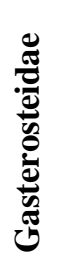 } & $\begin{array}{c}\text { Gasterosteus aculeatus } \\
\text { Linnaeus, } 1758\end{array}$ & $\begin{array}{l}\text { Three-spined } \\
\text { stickleback }\end{array}$ & A & WCEO & 7,8 & G-VII \\
\hline & & $\begin{array}{l}\text { Pungitius platygaster } \\
\text { (Kessler, 1859) }\end{array}$ & $\begin{array}{l}\text { Ukrainian } \\
\text { stickleback }\end{array}$ & $\mathrm{N}$ & WCEO & & G-V \\
\hline
\end{tabular}

Species diversity varied between different rivers within the Anzali Wetland catchment area with the most and the least number of fish species observed in the Siahdarvishan and Morghak Rivers with 52 and 11 species, respectively (Fig. 4).

The cyprinids were also dominant in the rivers (Table 1; Fig. 5). About $70-80 \%$ of the identified fish in the rivers were freshwater residents and the others were anadromous. Alburnus chalcoides (Güldenstaedt, 1772) and Carassius gibelio (Bloch, 1782) were distributed in all rivers, and Alburnoides samiii Mousavi-Sabet, Vatandoust and Doadrio, 2015, Alburnus hohenackeri Kessler, 1877, Capoeta razii Jouladeh-Roudbar, Eagderi, Ghanavi and Doadrio, 2017, Cobitis saniae Eagderi, Jouladeh-Roudbar, Jalili, Sayyadzadeh and Esmaeili, 2017, Gambusia holbrooki Girard, 1859, Hemiculter leucisculus (Basilewsky, 1855), Luciobarbus capito (Güldenstaedt, 1773), Ponticola gorlap (Iljin, 1949), Ponticola iranicus Vasil'eva, Mousavi-Sabet and Vasil'ev, 2015, Pseudorasbora parva (Temminck and Schlegel, 1846), Rhodeus amarus (Bloch, 1782), and Squalius turcicus De Filippi, 1865 were observed in more than $80 \%$ of the studied rivers (Table 1; Appendix 2).

Among the recognized fishes, four endemic (5.56\%) and 50 native species $(69.44 \%)$ were identified, while 18 species $(25 \%)$ are listed as exotic/alien (six of them are ornamental fish, introduced via the aquarium trade) (Fig. 6; Appendix 2). All the identified fish species in the Anzali Wetland basin belong to seven ecological groups (Table 1, Fig. 7). 


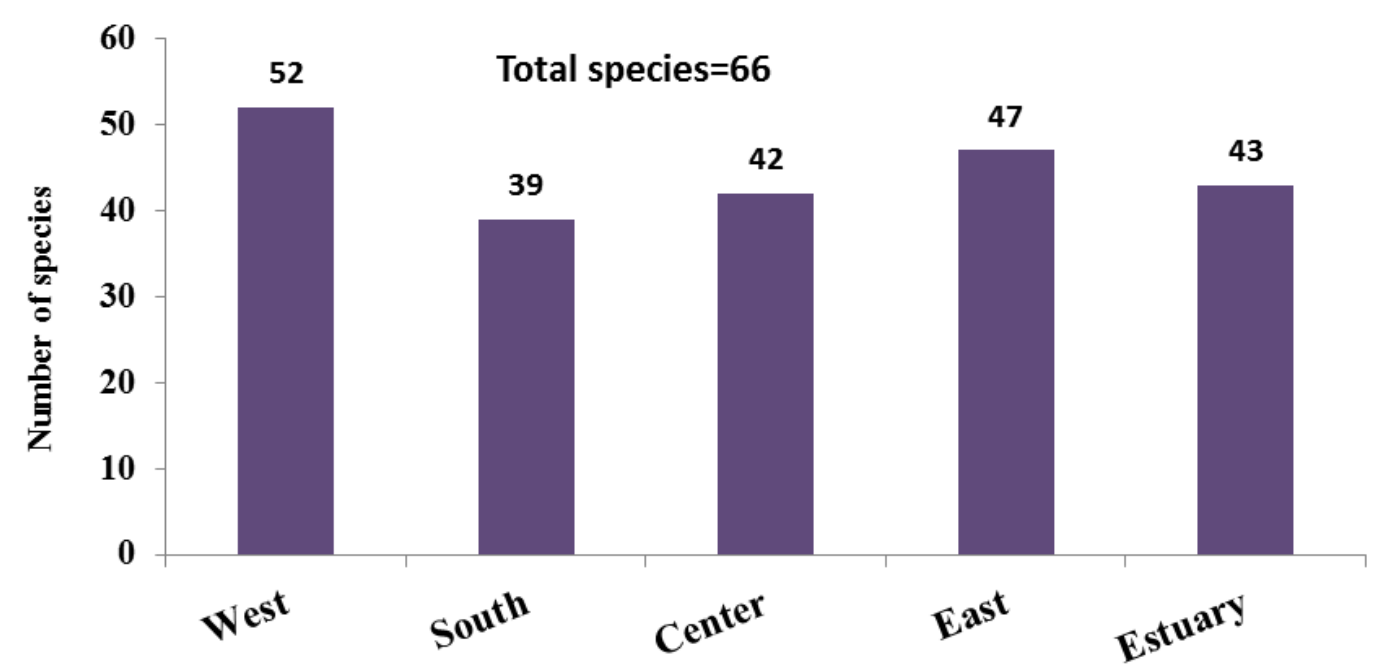

Figure 2: Number of fish species in different parts of the Anzali Wetland.

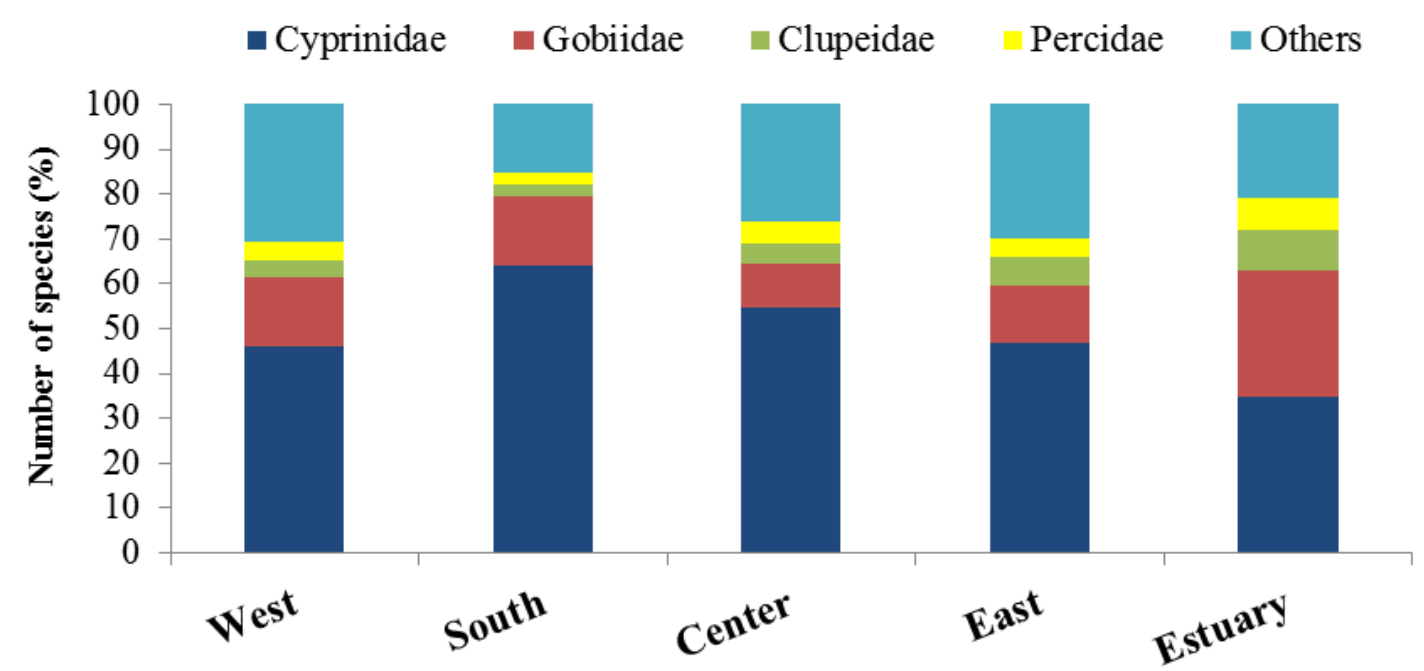

Figure 3: Number of species in each family in different parts of the Anzali Wetland.

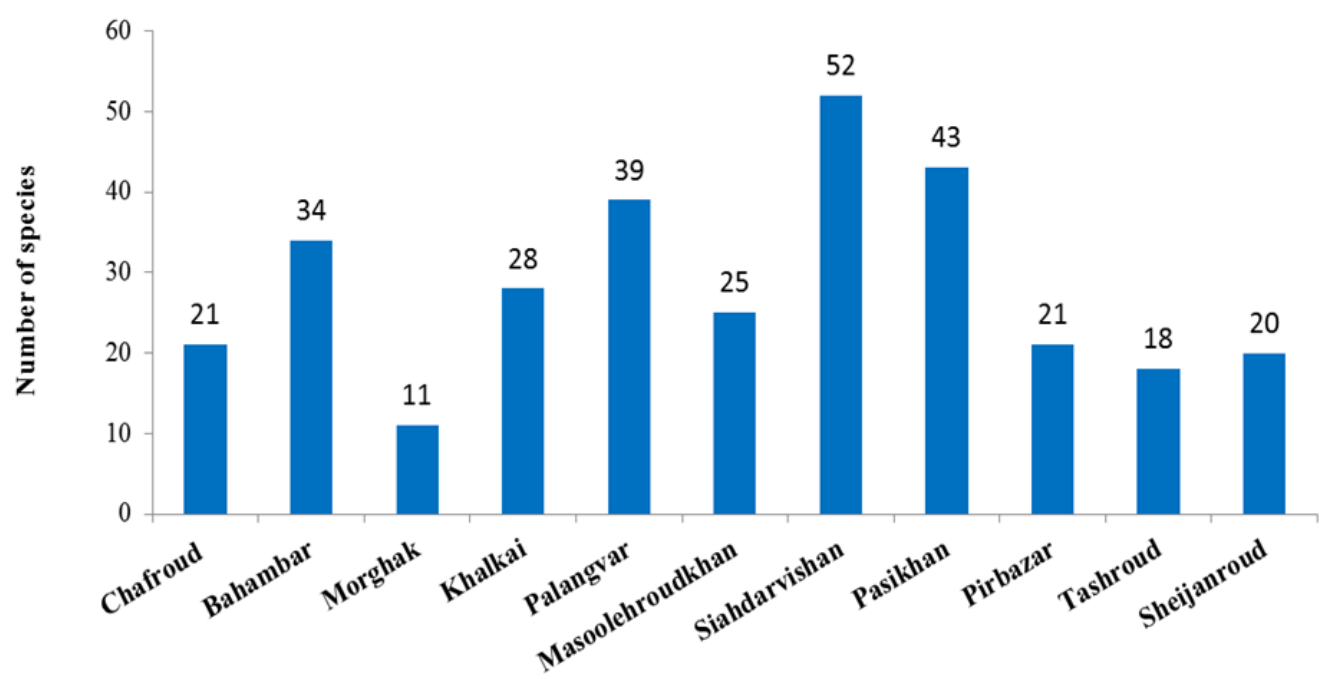

Figure 4: Number of fish species in different rivers of the Anzali Wetland basin. 


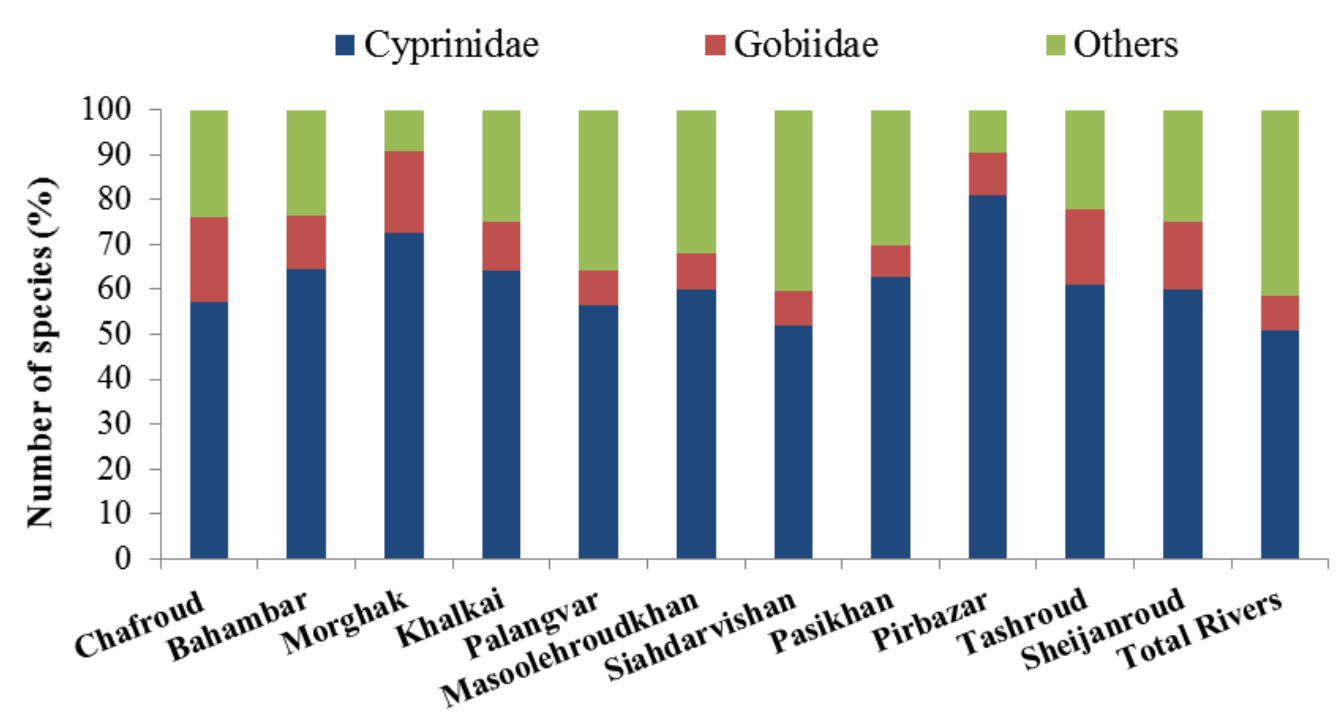

Figure 5: Number of species in each family in different rivers of the Anzali Wetland basin.

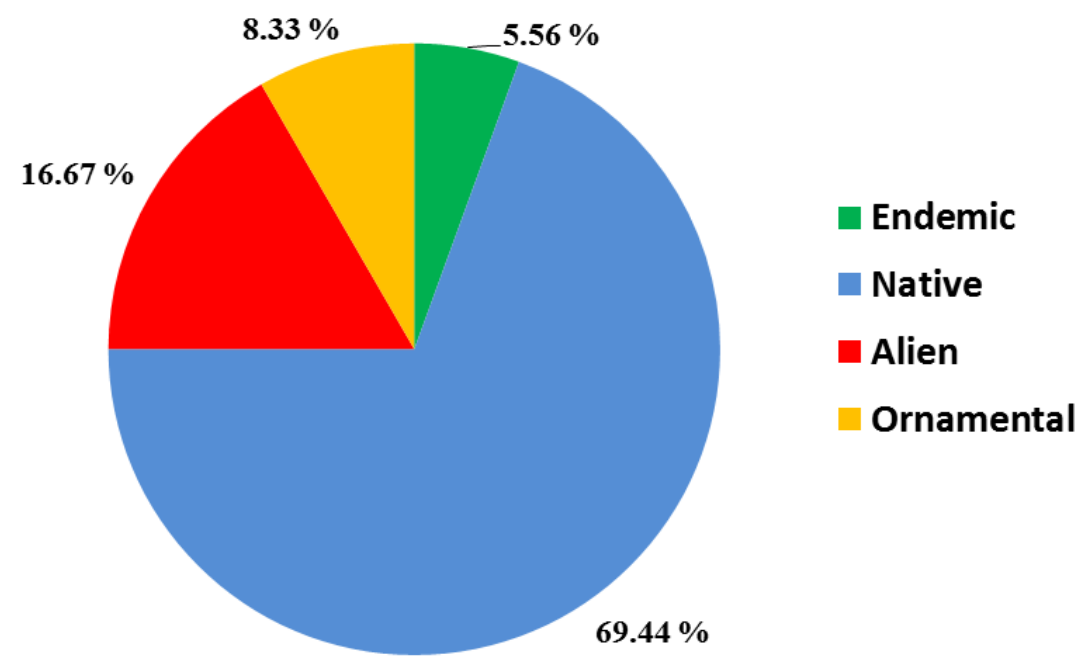

Figure 6: Origin of fish species in the Anzali Wetland basin.

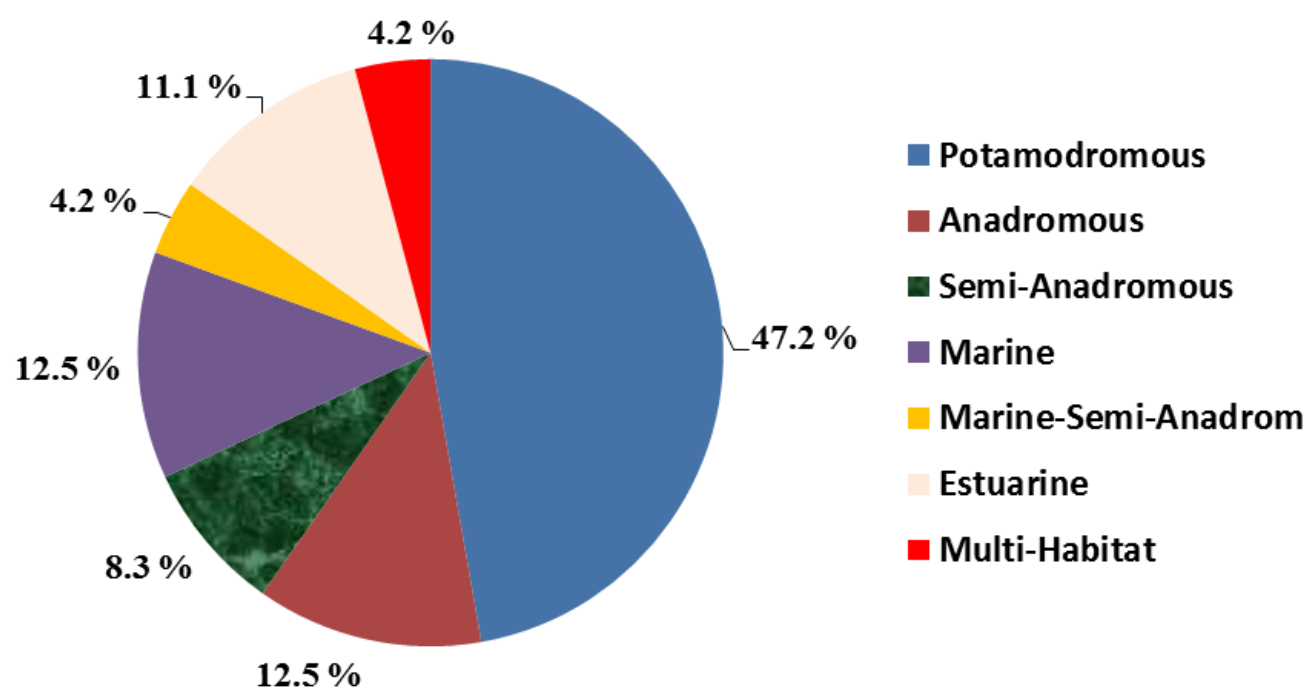

Figure 7: The ecological groups of identified fish species in the Anzali Wetland basin. 


\section{Discussion}

The present study shows the fish distribution in different parts of the Anzali Wetland and its related rivers for the first time. Here, we report 72 fish species from the Anzali Wetland basin, whereas previous reports included 26 species (Gmelin, 1785; Mel'gunov, 1836; Derzhavin, 1934; Kozhin, 1957, Hydrorybproject, 1965; RaLonde and Walczak, 1972), 41 species (Holcik and Oláh, 1992), 42 species (Karimpour, 1998) and 49 species (Abbasi et al., 1999). The longer sampling period, more sampled localities and the use of different fishing equipment in the present study are the main reasons for increasing the number of species. According to the obtained results, the number of exotic fishes is increasing in the Anzali Wetland in recent decades, especially due to the release of ornamental fishes through the aquarium trade.

The ichthyo-diversity of the Anzali Wetland is significantly richer than the other wetlands in the southern Caspian Sea basin, for example the Amirkelayeh Wetland with 15 species (Nezami Baluchie and Khara, 2004), Kiashahr National Park with 25 species (Khara and Nezami Baluchie, 2005), and Gomishan Wetland with 15 species (Patimar et al., 2009). The fish species richness of the wetland can be related to the permanent connection with the Caspian Sea, variable habitats, and the larger area of the Anzali Wetland in comparison with the other mentioned wetlands.

Due to the degradation of the Anzali Wetland environment, many areas were drained and others completely covered by dense aquatic plants. These changes could affect the fish diversity in different parts of the Anzali Wetland. The high sedimentation in the central and southern parts of wetland can be considered as the main reason for the low number of fishes in this region (Fig. 2).

Among the identified fishes, members of the family Cyprinidae were dominant inside the Anzali Wetland and its related rivers, similar to previous reports from the region (Holcik and Oláh, 1992; Abbasi et al., 1999; Nezami Baluchie and Khara, 2004; Khara and Nezami Baluchie, 2005; Patimar et al., 2009), and also from the rivers that discharge into the Caspian Sea from the southern part (Abbasi et al., 1998; 2007; 2011; 2014; Afraei and Lalooei, 2000; Abbasi, 2006a; 2006b; Mostafavi and Abdoli, 2006; Mostafavi, 2007; Banagar et al., 2009; Abdoli et al., 2014; Naderi Jelodar et al., 2016; Sarpanah et al., 2019). This is due to the high tolerance of cyprinids to habitat variation (Winfield and Nelson, 1991; Wootton, 1990).

Four freshwater species, B. cyri, O. bergianus, S. trutta and O. mykiss were only observed in the rivers and this shows their riverine dependence. Two species, A. persicus and A. stellatus were only observed in a few rivers. These are the Caspian anadromous fishes that have to pass through the corridor of the Anzali Wetland toward the rivers, but nowadays their abundance is very low in the Caspian Sea (Iran Fisheries Organization, 2017; Hashemi et al., 2019) and they are rarely observed in these freshwater regions.

In the adjacent rivers to the wetland, 23 species were previously reported by Holcik and Oláh (1992), in comparison with 53 identified fish species in the present investigation. It can be concluded that the longer sampling period with more sampling sites and various fishing techniques could have made the difference.

Nine species (particularly gobiids) are only observed in the estuarine region (Table 1) due to their main habitat in the brackish water of the Caspian Sea (Kazancheev, 1981; Abdoli and Naderi, 2009; Mirzajani et al., 2016; Abbasi, 2017), and it seems these species cannot enter the freshwater environments. Whereas A. chalcoides, A. hohenackeri, C. gibelio, $R$. amarus, $C$. saniae and $P$. gorlap are present in all areas inside the wetland and in almost all the adjacent rivers. 
Diversification of fish species in different rivers is related to ecological parameters such as length and width of rivers, water volume, type of substrate, situation of vegetation and manmade interventions such as dams and other barriers (Wootton, 1990; Rahel and Hubert, 1991). Generally more species diversity is observed in rivers which are longer in length, wider in width, lower in their slope, higher in aquatic plants (Varley, 1967; Rahel and Hubert, 1991), and also greater values of water flow and depth (Sheldon, 1968; Foltz, 1982; Adebisi, 1988). The Morghak is a short river with the least number of fish species while the Siahdarvishan is a long river with numerous streams and has the most number of fish species (Fig. 4). This pattern of ichthyo-diversity has been observed in many rivers, discharging to the southern Caspian Sea. Investigations of 20 rivers, flowing toward the southern Caspian Sea, by different authors (Ramin, 1997; Abbasi et al., 1998; 1999; 2007; 2011; 2014; Kiabi et al., 1999; Afraei and Lalooei, 2000; Abbasi and Sarpanah, 2001; Nazari, 2002; Abbasi, 2006a; 2006b; Mostafavi, 2007; Banagar et al., 2009; Abdoli et al., 2014; Naderi Jelodar et al., 2016; Sarpanah et al., 2019) showed that the number of fish species varied from 12 to 67 species.

Eighteen exotic, or alien, fish species were observed in the present study versus 7 and 9 reported species by Holcik and Oláh (1992) and Abbasi et al. (1999), respectively. Some of these alien fish were introduced with fisheries development to the Caspian Sea such as the golden grey mullet (Chelon auratus) and leaping mullet (C. saliens) (Kazancheev, 1981; Esmaeili et al., 2014b; 2018; Coad, 2016), while others were introduced for aquaculture purposes including Cyprinus carpio, Hypophthalmichthys molitrix, H. nobilis and O. mykiss. Two species Ctenopharyngodon idella and G. holbrooki were introduced to the Anzali Wetland to control aquatic plants and mosquitos, respectively (Coad, 2016; Esmaeili et al., 2014b; 2017; 2018). Most of the exotic species were introduced inadvertently to the Anzali Wetland as commercial species transplanted by Iranian Fisheries Organization (Shilat) for aquaculture developments, or released by people as ornamental fishes (Coad and Abdoli, 1993; Coad, 1995; 2016; 2019; Abdoli, 2000; Abdoli and Naderi, 2009; Esmaeili et al., 2014b; 2017; 2018; Keivany et al., 2016; Abbasi, 2017; Mousavi-Sabet, 2019).

At present, most water bodies have been occupied by alien species in Iran (Coad and Abdoli, 1993; Abdoli, 2000; Abbasi and Sarpanah, 2001; Abbasi et al., 1999; 2011; 2014; Khara and Nezami Balouchi, 2005; Mostafavi, 2007; Patimar et al., 2009; Naderi Jelodar et al., 2016; Abbasi, 2017; Coad, 2019; Sarpanah et al., 2019), and in some places the exotic species comprise 13 to $40 \%$ of identified fish species. The dispersal ability of exotic species might promote the risk of gene introgression and competition between wild and introduced fish, as well as disease transmission to wild populations (Naylor et al., 2005; Fisher et al., 2014).

In this study, A. samiii, C. razii, $C$. saniae and P. iranicus were recognized as Iranian endemic species (Mousavi-Sabet et al., 2015; Vasil'eva et al., 2015; Eagderi et al., 2017; JouladehRoudbar et al., 2017; Esmaeili et al., 2018) and a further 50 species were documented as Iranian native species (Kazancheev, 1981; Abdoli and Naderi, 2009; Esmaeili et al., 2014a; 2017; 2018; Coad, 2016; Froese and Pauly, 2019).

Using available literature (Berg, 1948; 1949a, b; Kazancheev, 1981; Wootton, 1990; Agarwal, 1999; Kottelat and Freyhof, 2007; Abdoli and Naderi, 2009; Coad, 2010; 2016; Keivany et al., 2016; Abbasi, 2017; Froese and Pauly, 2019), the identified species were divided into seven groups (Table 1, Fig. 7: G I-VII).

The freshwater resident or potamodromous species (G-I) include 34 species that exist inside the Anzali Wetland and its adjacent rivers, and are rarely observed in the estaurine region (inshore) for the purpose of feeding. According to potamodromous behavior (Acolas and Lambert, 2016), these species may move between the Anzali Wetland and its adjacent rivers to find suitable spawning grounds or feeding areas. 
Nine species $(12.5 \%)$ are anadromous (G-II) which live in the Caspian Sea and migrate to the Anzali Wetland and its adjacent rivers for spawning. While Pelecus cultratus spawn freely in open water, two species Vimba persa and Rutilus kutum are phytophilus-lithophilus and other species are only lithophilus and require aquatic vegetation or gravel substrates for spawning. Six species (G-III) are semi-anadromous existing in all regions and needing freshwater areas for spawning.

Nowadays, as a global problem (e.g., see Lassalle and Rochard, 2009; Vignon and Sasal, 2010; Johnson et al., 2013), barriers, pollution, modification of the hydraulic regime, substrate destruction, and illegal fisheries activities along rivers cause many threats to the spawning of anadromous fish species.

Nine species (G-IV) are marine fish, observed only in the Caspian Sea and they never enter into rivers, but remain in the estuarine region for feeding and spawning. Three species $(\mathrm{G}-\mathrm{V})$ were mostly observed in the estuarine region, rarely inside the wetland and downstream of some rivers, and they spawn in both freshwater and the Caspian Sea environment. Eight species (G-VI) were mostly observed in the Caspian Sea and rarely inside the wetland but these species were not observed in rivers.

Three species (G-VII) P. gorlap, Proterorhinus nasalis and Gasterosteus aculeatus were recorded from all regions; inside the wetland, rivers and estuary in all seasons and they can spawn both in freshwater and brackish water (estuary). The European eel, Anguilla anguilla, although it is a catadromous fish species (Froese and Pauly, 2019) hitherto has been reported from the coast and not from its rivers in the southern Caspian Sea (Kazancheev, 1981; Abdoli and Naderi, 2009; Coad, 2010; 2016; Keivany et al., 2016; Abbasi, 2017).

There are two previously reported species Abramis sapa bergi Belyaev, 1929 (now Ballerus sapa (Pallas 1814)) and Platichthys flesus luscus Pallas, 1811 (now Platichthys flesus (Linnaeus, 1758)) from the Anzali Wetland (Gmelin, 1785; Mel'gunov, 1836; Derzhavin, 1934; Kozhin, 1957; Hydrorybproject, 1965; RaLonde and Walczak, 1972) with no new records (Holcik and Oláh, 1992; Karimpour, 1998; Abbasi et al., 1999; Abdoli and Naderi, 2009; Coad, 2016; Abbasi, 2017; Esmaeili et al., 2018; present study).

Twenty fish species are recorded for the first time from the Anzali Wetland basin, including 10 estuarine species (Alosa braschnikowi, A. kessleri, Benthophilus ctenolepidus, B. leobergius, Neogobius caspius, Ponticola bathybius, P. goebelii, P. syrman, Sander marinus and Chelon saliens), five ornamental fish (P. brachypomus, P. sanitwongsei, H. plecostomus, $C$. micropeltes and $P$. reticulata), a rare upstream fish $(S$. trutta), a rare anadromous fish $(A$. persicus), a rare multi-habitat fish (K. caucasica), a newly small exotic fish ( $R$. lindbergi) and an escaped farm fish (O. mykiss).

Based on the obtained results it can be concluded that 66 species (with the exception of six rare ornamental fishes) exist in different regions of the Anzali Wetland. Some of these species are rare with low abundance. Many species (20 species) belong to the Caspian Sea environment which are dependent on the Anzali Wetland due to different reasons, particularly for reproduction. Conservation of different habitats of the Anzali Wetland is necessary to preserve rare, freshwater and anadromous fish species.

\section{Acknowledgments}

We appreciate Haibatollah Norouzi, Asghar Sedaghatkish, Reza Ramzani, Mostafa Sayyadrahim, Moharram Iranpour, Abbas Ravan Ramzani, Masoud Mahboob, Shaban 
Rohbani, Reza Mohammadidost, Gholamreza Mehdizadeh, Hojat Khodaparast, Alinaghi Sarpanah, Alireza Valipour, Davoud Haghighi, for their help in sampling and laboratory work. We would like to thank staff from the Department of Environment, Inland Water Aquaculture Research Center, and Japan International Corporation Agency (JICA) for financial support of ichthyology studies.

\section{References}

Abbasi, K. (2006a). Identification and distribution of fish fauna in Shafarud River, Guilan Province. Iranian Scientific Fisheries Journal, 15 (2): 73-86. [in Persian]

Abbasi, K. (2006b). Identification and distribution of fish fauna in Hevigh River (Guilan Province). Iranian Journal of Biology, 18 (4): 370-382. [in Persian]

Abbasi, K. (2017). Fishes of Guilan. The Encyclopedia of Guilan Culture and Civilazation. 66: 205 pp. [in Persian]

Abbasi, K., Moradkhah, S. and Sarpanah, A. N. (2007). Identification and distribution of fish fauna in Siahdarvishan River (Anzali Wetland basin). Quarterly Pajouhesh-vaSazandegi, 19 (1): 27-39. [in Persian]

Abbasi, K., Noroozi, H. and Sayyad Rahim, M. (2011). Identification, abundance and diversity, richness and evenness indices in Karganrud River fishes (Guilan Province). New Technologies in Aquaculture Development (Journal of Fisheries), 5 (2):113-126. [in Persian]

Abbasi, K. and Sarpanah, A. N. (2001). Fish fauna investigation in Arass Reservoir and its Iranian tributaries. Iranian Scientific Fisheries Journal, 10 (2): 41-62. [in Persian]

Abbasi, K., Sarpanah, A. N. and Moradi, M. (2014). Check list of recent fish species of Sefid River. The Second Iranian Conference of Ichthyology, 99-104. Tehran University, Karaj. [in Persian]

Abbasi, K., Sarpanah, A. N. and Nezami, S. (1998). A survey on fish diversity (Ichthyofauna) of Sefidroud River. Quarterly Pajouhesh-va-Sazandegi, 39 (2): 104-109. [in Persian]

Abbasi, K., Valipour, A. R., Talebi Haghighi, D., Sarpanah, A. N. and Nezami, S. (1999). Atlas of Iranian Fishes. Gilan Inland Waters. Guilan Fisheries Research Center, Bandar Anzali, Iran. 113 pp. [in Persian]

Abdoli, A. (2000). The Inland Water Fishes of Iran. Iranian Museum of Nature and Wildlife, Tehran, Iran. 378 pp. [in Persian]

Abdoli, A. and Naderi, M. (2009). Biodiversity of Fishes of the Southern Basin of the Caspian Sea. Abzian Scientific Publications, Tehran, Iran. 243 pp. [in Persian]

Abdoli, A., Naderi, M., Foroughifard, H. and Kiabi, B. H. (2014). Fish diversity and distribution in two protected rivers, Sardabrud and Chalus, southern Caspian Sea basin, Iran. Iranian Journal of Ichthyology, 1 (2): 91-95.

Acolas, M. L. and Lambert, P. (2016). Life histories of anadromous fishes, In: Morais, P. and Daverat, F. (Eds.), An introduction to fish migration. First Edition. CRC Press, Boca Raton, FL, pp. 55-77.

Adebisi, A. A. (1988). Changes in the structural and functional components of the fish community of a seasonal river. Archiv für Hydrobiologie, 113 (3): 457-463.

Afraei, M. and Lalooei, F. (2000). Fishes distribution assay in Tonekabon River. Iranian Scientific Fisheries Journal, 9 (1): 1-14. [in Persian]

Agarwal, B. (1999). Fishes Reproduction. Translated by: Kamali, I. and Valinasab, T. 2004. Iranian Fisheries Research Organization, Tehran, Iran. 258 pp. [in Persian] 
Banagar, G. R., Karami, M., Hasanzadeh Kiabi, B. and Ghasempouri, S. M. (2009). Distribution and biodiversity of fish species in Haraz River in Mazandaran Province. Environmental Sciences, 6 (2): 21-31. [in Persian]

Berg, L. S. (1948). Freshwater fishes of the U.S.S.R. and adjacent countries. Volume 1. Trady Institute Acad, Nauk U.S.S.R. 496 pp.

Berg, L. S. (1949a). Freshwater fishes of the U.S.S.R. and adjacent countries. Volume 2. Trady Institute Acad, Nauk U.S.S.R. 504 pp.

Berg, L. S. (1949b). Freshwater fishes of the U.S.S.R. and adjacent countries. Volume 3. Trady Institute Acad, Nauk U.S.S.R. 510 pp.

Coad, B. W. (1995). Freshwater Fishes of Iran. Acta Scientiarum Naturalium Academiae Scientiarum Bohemicae, Brno, 29(1):1-64.

Coad, B. W. (2005). The freshwater fishes of Iran. www.briancoad.com (Accessed 18 August 2005).

Coad, B. W. (2010). The freshwater fishes of Iran. www.briancoad.com (Accessed 3 Nov. 2010).

Coad, B. W. (2016). The freshwater fishes of Iran. www.briancoad.com (Accessed 12 Aug. 2016).

Coad B. W. (2019). Review of the gobionids of Iran (Family Gobionidae). Iranian Journal of Ichthyology, 6 (1): 1-20. http://dx.doi.org/10.22034/iji.v6i1.325

Coad, B. W. and Abdoli, A. (1993). Exotic fish species in the fresh waters of Iran. Zoology in the Middle East, 9 (1): 65-80. http://dx.doi.org/10.1080/09397140.1993.10637648

Derzhavin, A. N. (1934). Presnovodnye ryby yuzhnogo poberezh'ya Kaspiya. Vstuplenie [Freshwater fishes of the southern shore of the Caspian Sea. Introduction]. Trudy Azerbaidzhanskogo Otdeleniya Zakavkazskogo Filiala Akademii Nauk SSSR, Sektor Zoologii, Baku, 7: 91-126.

Eagderi, S., Jouladeh-Roudbar, A., Jalili, P., Sayyadzadeh, G. and Esmaeili, H. R. (2017). Taxonomic status of the genus Cobitis Linnaeus, 1758 (Teleostei: Cobitidae) in the southern Caspian Sea basin, Iran with description of a new species. FishTaxa, 2 (1): 4861.

Esmaeili, H. R., Coad, B. W., Mehraban, H. R., Masoudi, M., Khaefi, R., Abbasi, K., Mostafavi, H. and Vatandoust, S. (2014a). An updated checklist of fishes of the Caspian Sea basin of Iran with a note on their zoogeography. Iranian Journal of Ichthyology, 1 (3): 152-184.

Esmaeili, H. R., Teimori, A., Owfi, F., Abbasi, K. and Coad, B. W. (2014b). Alien and invasive freshwater fish species in Iran: diversity, environmental impacts and management. Iranian Journal of Ichthyology, 1 (2): 61-72.

Esmaeili, H. R., Mehraban, H. R., Abbasi, K., Keivany, Y. and Coad, B. W. (2017). Review and updated checklist of freshwater fishes of Iran: Taxonomy, distribution and conservation status. Iranian Journal of Ichthyology, 4 (1): 1-114. http://dx.doi.org/10.7508/iji.2017

Esmaeili, H. R., Sayyadzadeh, G., Eagderi, S. and Abbasi, K. (2018). Checklist of freshwater fishes of Iran. FishTaxa, 3 (3): 1-95.

Fisher, A. C., Volpe, J. P. and Fisher, J. T. (2014). Occupancy dynamics of escaped farmed Atlantic salmon in Canadian Pacific coastal salmon streams: implications for sustained invasions. Biological Invasions, 16: 2137-2146. https://doi.org/10.1007/s10530-0140653-x 
Fricke, R., Eschmeyer, W. N. and van der Laan, R. (2019). Eschmeyer's Catalog of Fishes: Genera, Species, References. Electronic version. http://researcharchive.calacademy.org/research/ichthyology/catalog/fishcatmain.asp (Accessed 17 November 2019).

Foltz, J. W. (1982). Fish species diversity and abundance in relation to stream habitat characteristics. Proceedings of the Annual Conference of the Southeastern Association of Fish and Wildlife Agencies, 36: 305-311.

Froese, R. and Pauly, D. (2019). FishBase. World Wide Web electronic publication. www.fishbase.org (Accessed 10 November 2019).

Gmelin, G. (1785). Puteshestvie po Rossii dlya issledovaniya vsekh trekh tsarstv prirody. Sankt Petersburg. [in Russian]

Hashemi, S. A., Taghavi Motlagh, S. A., Hedayati, A. and Fazli, H. (2019). Fishing-inbalance, mean trophic level, ratio of pelagic and demersal fish landings and piscivory indices of coastal fisheries landings in Iranian part of the Caspian Sea. Iranian Journal of Ichthyology, 6 (2): 112-122. http://dx.doi.org/10.22034/iji.v6i2.293

Holcik, J. (1989). The freshwater fishes of Europe. Volume 1, Part II. General introduction to fishes, Acipenseriformes. AULA-Verlag, Wiesbaden. 469 pp.

Holcik, J. and Oláh, J. (1992). Fish, fisheries and water quality in Anzali Lagoon and its watershed. Report prepared for the project- Anzali Lagoon productivity and fish stock investigations. Food and Agriculture Organization, Rome, FI: UNDP/IRA/88/001 Field Document 2: $\mathrm{x}+109 \mathrm{pp}$.

Hydrorybproject (1965). Fish-cultural reclamation of the Anzali (Mordab) Bay. State Industrial Fisheries Committee, U.S.S.R., State Design Institute on Hydrotechnical, FishCultural Reclamation and Land Construction, Moscow. 60 pp.

Iran Fisheries Organization (2017). Statistics of catch and aquaculture fisheries in Iranian waters in 2012-2016. Tehran. 64 pp. [in Persian]

Johnson, L., Anulacion, B., Arkoosh, M., Olson, O. P., Sloan, C., Sol, S. Y., Spromberg, J., Teel, D. J., Yanagida, G. and Ylitalo, G. (2013). Persistent organic pollutants in juvenile Chinook salmon in the Columbia River Basin: implications for stock recovery. Transactions of the American Fisheries Society, 142 (1): 21-40. https://doi.org/10.1080/00028487.2012.720627

Jouladeh-Roudbar, A., Eagderi, S., Ghanavi, H. R. and Doadrio, I. (2017). A new species of the genus Capoeta Valenciennes, 1842 from the Caspian Sea basin in Iran (Teleostei, Cyprinidae). ZooKeys, 682: 137-155. https://doi.org/10.3897/zookeys.682.12670

Karimpour, M. (1998). The ichthyofauna of Anzali Lagoon. Iranian Journal of Fisheries Sciences, 7(2): 83-94. [in Persian]

Kazancheev, E. N. (1981). Ryby Kaspiiskogo Morya [Fishes of the Caspian Sea]. Legkaya i Pischchevaya Promyshlennost, Moskva. 167 pp.

Keivany, Y., Nasri, M., Abbasi, K. and Abdoli, A. (2016). Atlas of Inland Water Fishes of Iran. Iran Department of Environment, Tehran. 216 pp. [in Persian and English]

Khara, H. and Nezami Baluchie, S. (2005). Studying fish biodiversity and abundance in Boujagh Wetland of Kiashahr, south-western Caspian Sea. Iranian Scientific Fisheries Journal, 13 (4): 41-54. [in Persian]

Kiabi, B. H., Abdoli, A. and Naderi, M. (1999). Status of the fish fauna in the south Caspian Basin of Iran. Zoology in the Middle East, 18 (1): 57-65. https://doi.org/10.1080/09397140.1999.10637782 
Kimbal, K. D. and Kimbal, S. F. (1974). The limnology of the Anzali Mordab, Iran: A study of eutrophication problems. Human Environment Division, Department of the Environment, Iran. 43 pp.

Kottelat, M. and Freyhof, J. (2007). Handbook of European freshwater fishes. Kottelat, Cornol, Switzerland and Freyhof, Berlin, Germany. xiii + 646 pp.

Kozhin, N. I. (1957). Materialy po ikhtiofaune iranskogo poberezh'ya Kaspiya [Material on the ichthyofauna of the Iranian coast of the Caspian Sea]. Voprosy Ikhtiologii, 8: 8-18. [In Russian]

Lassalle, G. and Rochard, E. (2009). Impact of twenty-first century climate change on diadromous fish spread over Europe, North Africa and the Middle East. Global Change Biology, 15 (5): 1072-1089. https://doi.org/10.1111/j.1365-2486.2008.01794.x

Mel'gunov, G., (1863). O yuzhnom berege Kaspiiskogo morya. Prilozhenie k t. III. Zapiski Akademii Nauk, No. 5. [In Russian]

Mirzajani, A. (2009). Limnological survey of Anzali wetland based on ten years data 19902003 by use of GIS system. Agricultural Research and Education Organization, Inland Water Aquaculture Research Center, Iran. 117 pp.

Mirzajani, A. R., Khodaparast Sharifi, H., Babaei, H., Abedini, A. and Dadai Ghandi, A. (2010). Eutrophication trend of Anzali Wetland based on 1992-2002 Data. Journal of Environmental Studies, 35 (52): 19-21.

Mirzajani, A., Hamidian, A. H., Abbasi, K. and Karami, M. (2016). Distribution and abundance of fish in the southwest of Caspian Sea coastal waters. Russian Journal of Marine Biology, 42: 178-189. https://doi.org/10.1134/S1063074016020073

Mostafavi, H. (2007). Fish biodiversity in Talar River, Mazandaran Province. Journal of Environmental Studies, 32 (40): 127-135. [in Persian]

Mostafavi, H. and Abdoli, A. (2006). Fish species diversity, distribution and abundance in Kesseliian Stream, Mazandaran, Iran. Journal of Environmental Sciences, 12 (6): 25-32.

Mousavi-Sabet, H., Vatandoust, S. and Doadrio, I. S. (2015). Review of the genus Alburnoides Jeitteles, 1861 (Actinopterygii, Cyprinidae) from Iran with description of three new species from the Caspian Sea and Kavir basins. Caspian Journal of Environmental Sciences, 13 (4): 293-331.

Mousavi-Sabet, H. (2019). Exotic ornamental fishes in Iranian inland water basins: an updated checklist. Journal of Animal Diversity, 1 (1): 1-10. https://doi.org/10.29252/JAD.2019.1.1.1

Naderi, M. and Abdoli, A. (2004). Fish Species Atlas of South Caspian Sea Basin (Iranian Waters). Iranian Fisheries Research Organization, Teheran. 112 pp. [in Persian and English]

Naderi Jelodar, M., Rouhi, A. and Parafkandeh Haghighi, F. (2016). The importance of Tejan River in protection of fish species of southern Caspian Sea. Journal of Aquatic Caspian Sea, 1 (2): 25-34. [in Persian]

Naderi, S., Mirzajani, A. and Hadipour, E. (2017). Distribution of and threats to the Eurasian Otter (Lutra lutra) in the Anzali Wetland, Iran. IUCN/SCC Otter Specialist Group Bulletin, 34 (2): 84-94.

Naylor, R., Hindar, K., Fleming, I. A., Goldburg, R., Williams, S., Volpe, J., Whoriskey, F., Eagle, J., Kelso, D. and Mangel, M. (2005). Fugitive salmon: assessing the risks of escaped fish from net-pen aquaculture. BioScience, 55 (5): 427-437. https://doi.org/10.1641/0006-3568(2005)055[0427:FSATRO]2.0.CO;2 
Nezami Baluchie, S. and Khara, H. (2004). Species composition and abundance of fishes in Amirkelayeh Wetland. Iranian Scientific Fisheries Journal, 12 (4): 193-206. [in Persian]. https://doi.org/10.22092/isfj.2004.113709

NGO-IRAN. (2003). The Gazetteer of Rivers in the I.R. of Iran: Caspian Sea Watershed. National Geographical Organization Publication, Tehran. 312 pp.

Nazari, K. (2002). Identification of different fish species in Kargan-Rood River on Guilan Province. Iranian Scientific Fisheries Journal, 11 (1): 73-84. [in Persian]

Nelson, J. S. (1994). Fishes of the World. Third Edition. John Wiley and Sons, Inc. New York. $600 \mathrm{pp}$.

Nelson, J. S. (2006). Fishes of the World. Fourth Edition. John Wiley and Sons, Inc. Hoboken, New Jersey. 601 pp.

Nelson, J. S., Grande, T. C. and Wilson, M. V. H. (2016). Fishes of the World. Fifth Edition. John Wiley and Sons, Inc., Hoboken, New Jersey. 707 pp.

Patimar, R., Abdoli, A., Hasanzade Kiabi, B., Allahyari, S. and Naderi Jelowdar, M. (2009). Fish species diversity of the coastal areas in Gomishan Wetland. Journal of Agricultural Sciences and Natural Resources, 16 (Special issue 1-A). 10 pp. [in Persian]

Rahel, F. J. and Hubert, W. A. (1991). Fish assemblages and habitat gradients in a rocky mountain-great plains stream: biotic zonation and additive patterns of community change. Transaction of the American Fisheries Society, 120 (3): 319-332. https://doi.org/10.1577/1548-8659(1991)120<0319:FAAHGI>2.3.CO;2

RaLonde, R., and Walczak, P. (1972). A review of Shilot's bony fishing policy from 19291972. Report of the Fisheries Research Institute, Bandar Anzali. 10 pp.

Ramin, M. (1997). Indentification (sic) of Babolrud River's fish fauna. Iranian Fisheries Scientific Journal, 6 (3): 59-72. [in Persian]

Sarpanah, A., Abbasi, K. and Mehdizadeh, Gh. (2019). The role of rivers of western region of Guilan Province in rebuilding of anadromous fishes of Caspian Sea. Journal of Aquatic Caspian Sea, 4 (1): 50-61. [in Persian]

Sheldon, A. L. (1968). Species diversity and longitudinal succession in stream fishes. Ecology, 49 (2): 193-198. https://doi.org/10.2307/1934447

Svetovidov, A. N. (1952). Fauna of the U.S.S.R., Fishes. Volume 2. No. 1. Clupeidae. Zoological Institute of the Academy of Sciences of the U.S.S.R., Leningrad. 428 pp.

Varley, M. E. (1967). British Freshwater Fishes: Factors affecting their distribution. Fishing News Book, London. 142 pp.

Vasil'eva, E. D, Mousavi-Sabet, H. and Vasil'ev, V. P. (2015). Ponticola iranicus sp. nov. (Actinopterygii: Perciformes: Gobiidae) from the Caspian Sea basin. Acta Ichthyologica et Piscatoria, 45 (2): 189-197. https://doi.org/10.3750/AIP2015.45.2.09

Vignon, M. and Sasal, P. (2010). Fish introduction and parasites in marine ecosystems: a need for information. Environmental Biology of Fishes, 87 (1): 1-8. https://doi.org/10.1007/s10641-009-9553-9

Winfield, I. J. and Nelson J. S. (1991). Cyprinid fishes: Systematics, biology and exploitation. First Edition. Fish and Fisheries Series 3. Chapman and Hall. 667 pp.

Wootton, R. J. (1990). Ecology of teleost fishes. Fish and Fisheries Series 1. Chapman and Hall, London. 404 pp. 
Appendix 1: Different habitats in the Anzali wetland basin, including five parts of the wetland, as follow: Western, Southern, Central, Eastern, Estuary (A-E), and eleven rivers, including, Chafroud (F), Bahambar (G), Morghak (H), Khalkai (I), Palangvar (J), Masoolehroudkhan (K), Siahdarvishan (L), Pasikhan (M), Pirbazar (N), Tashroud (O) and Sheijanroud (P), respectively.

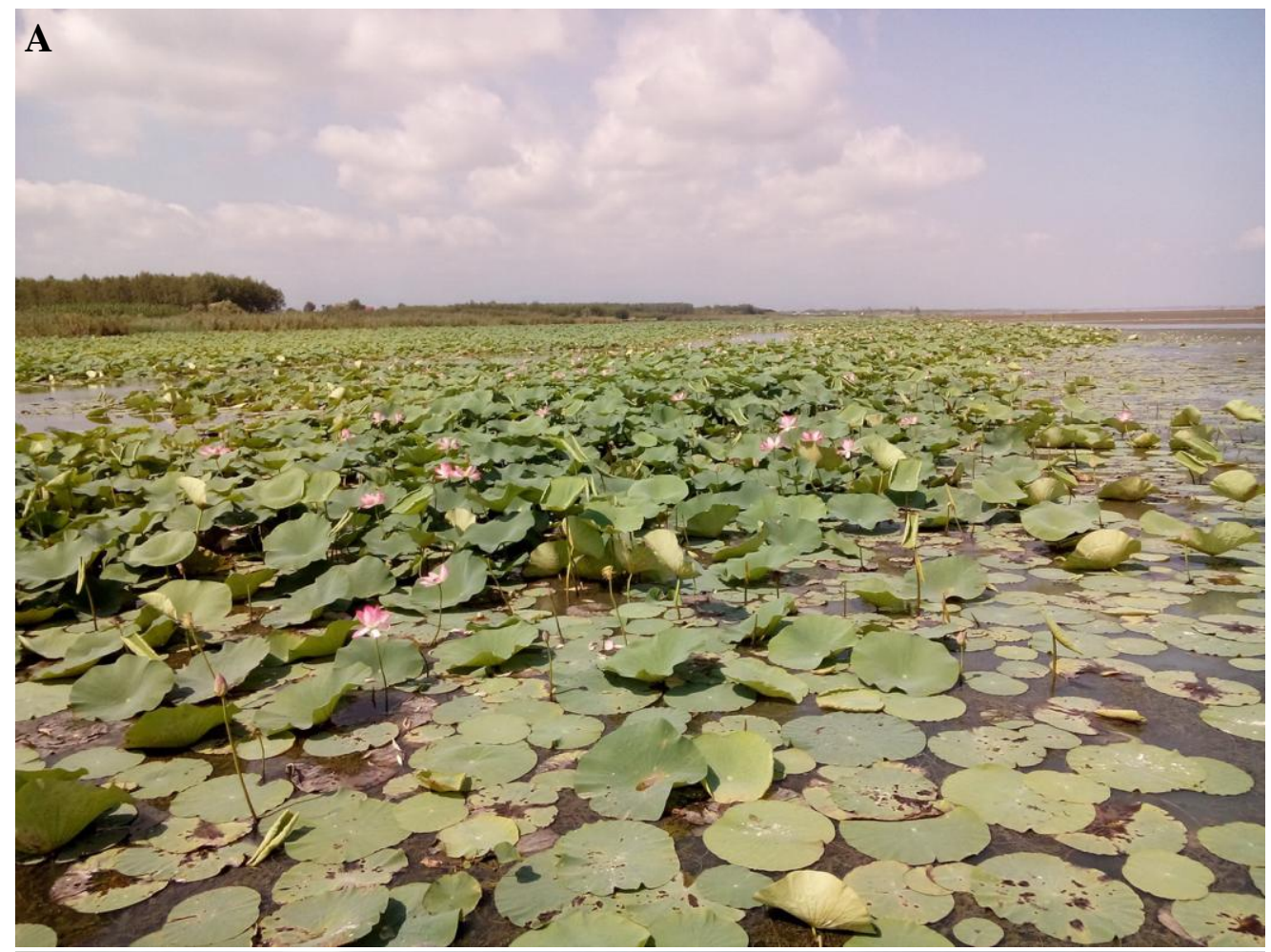

B

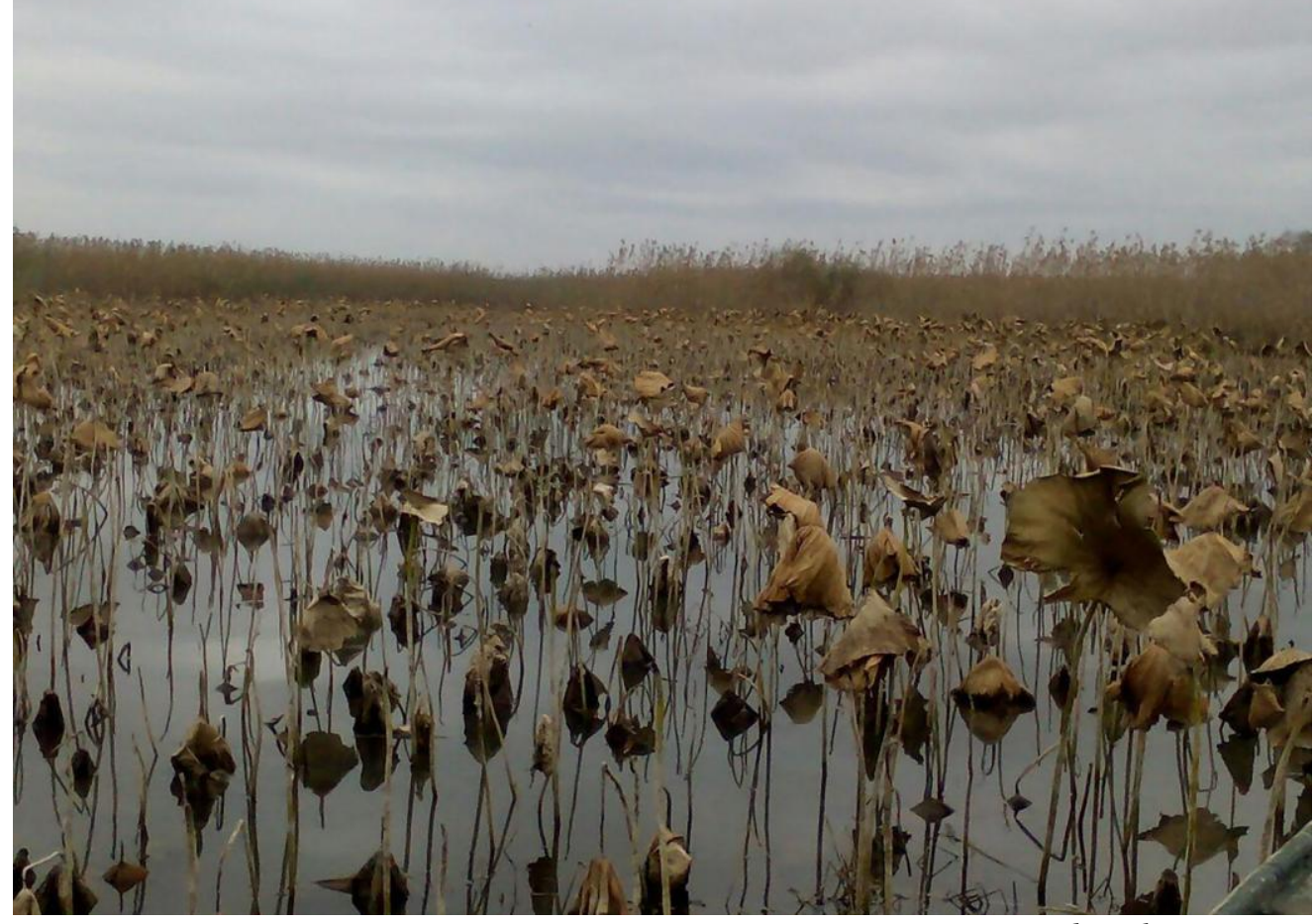

......continued on the next page 


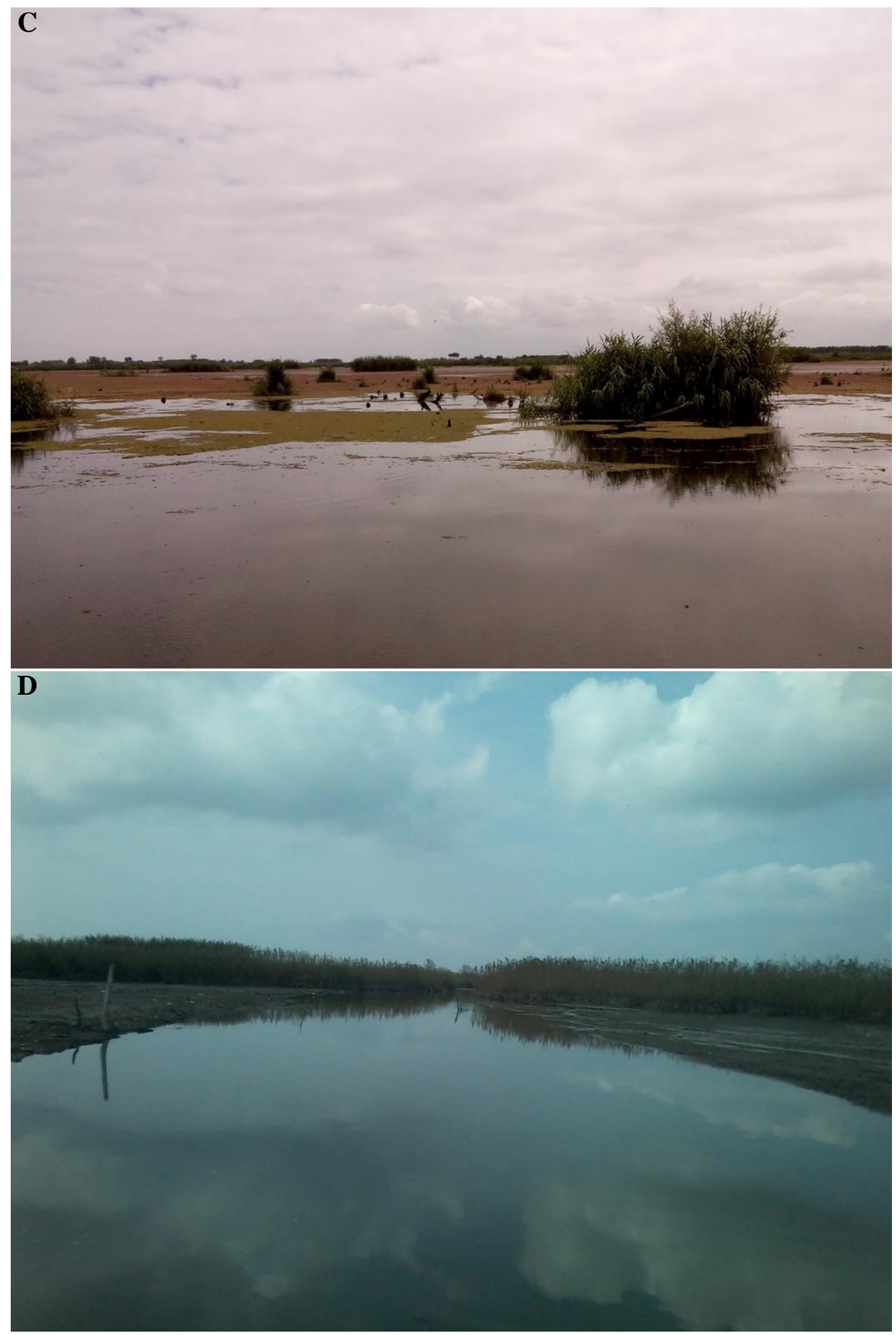

......continued on the next page 


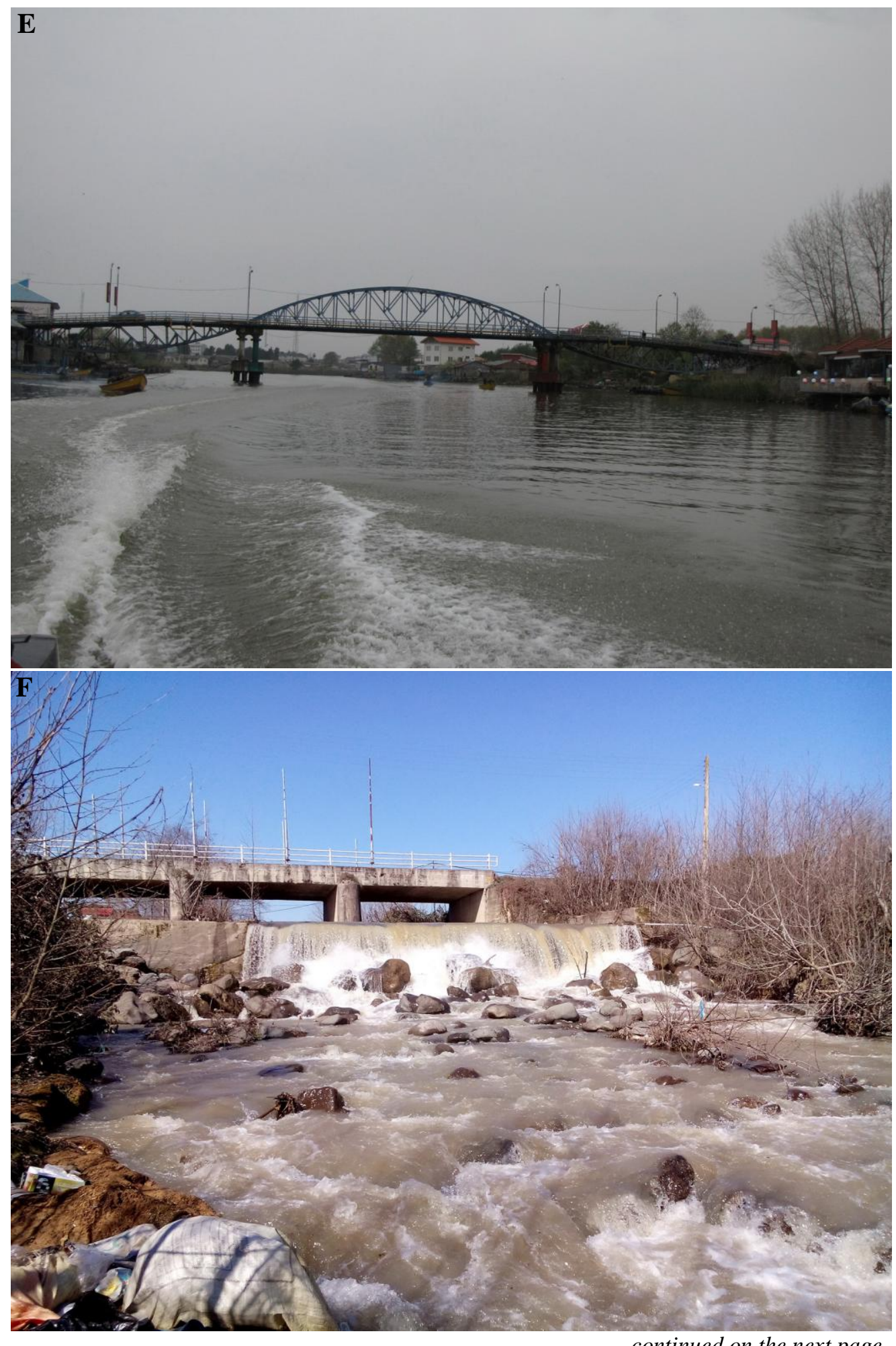

......continued on the next page 

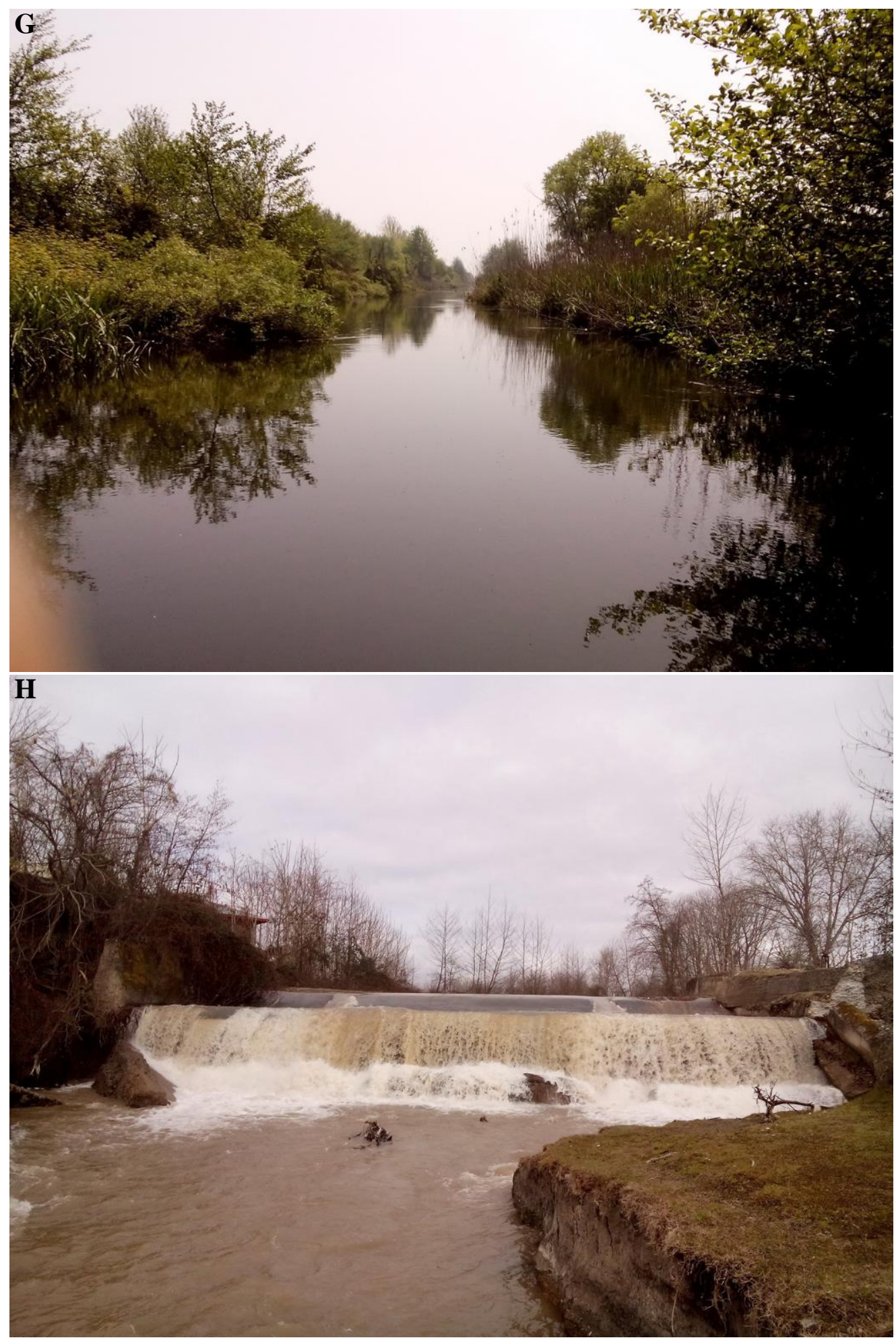

......continued on the next page 
I

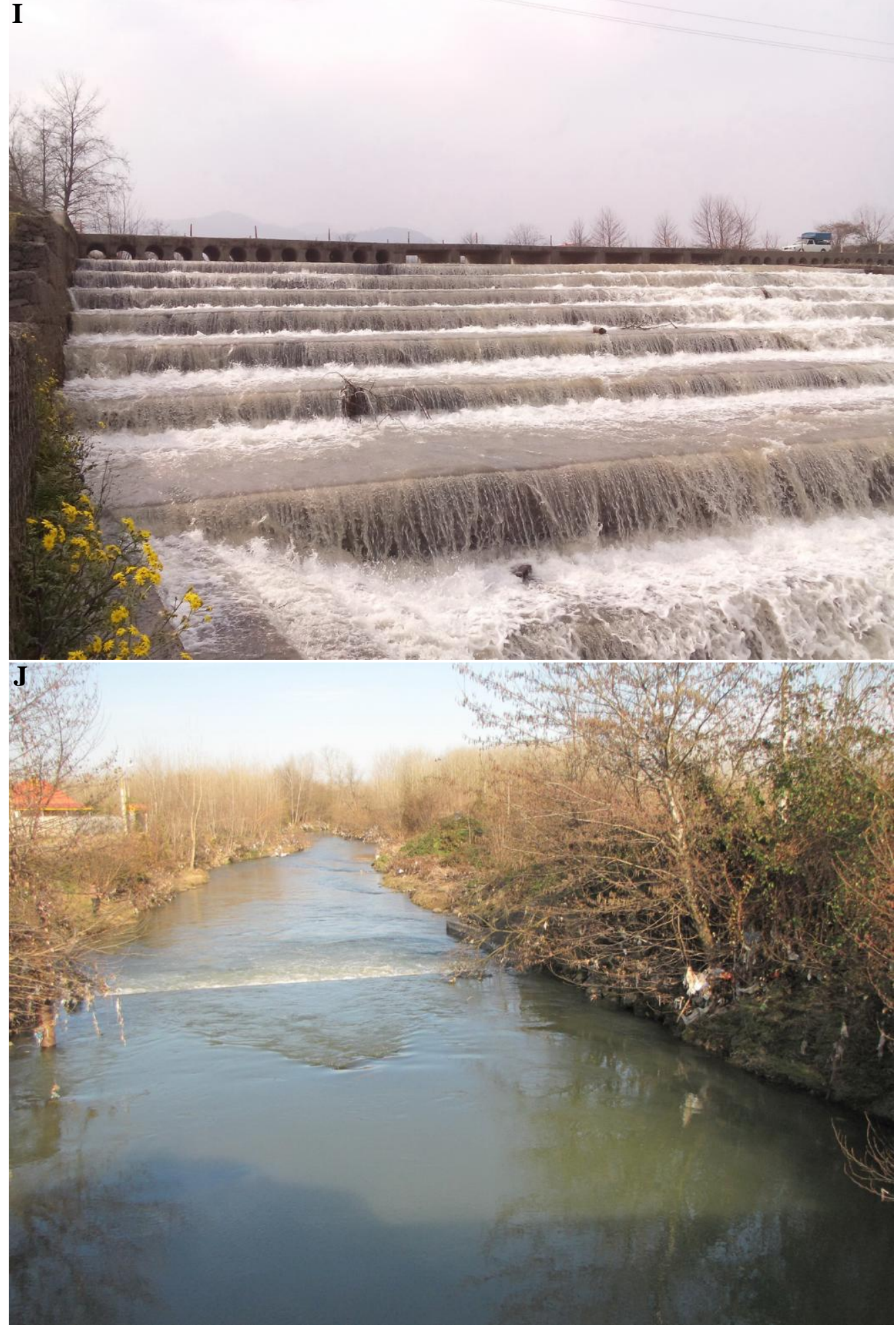

.......continued on the next page 


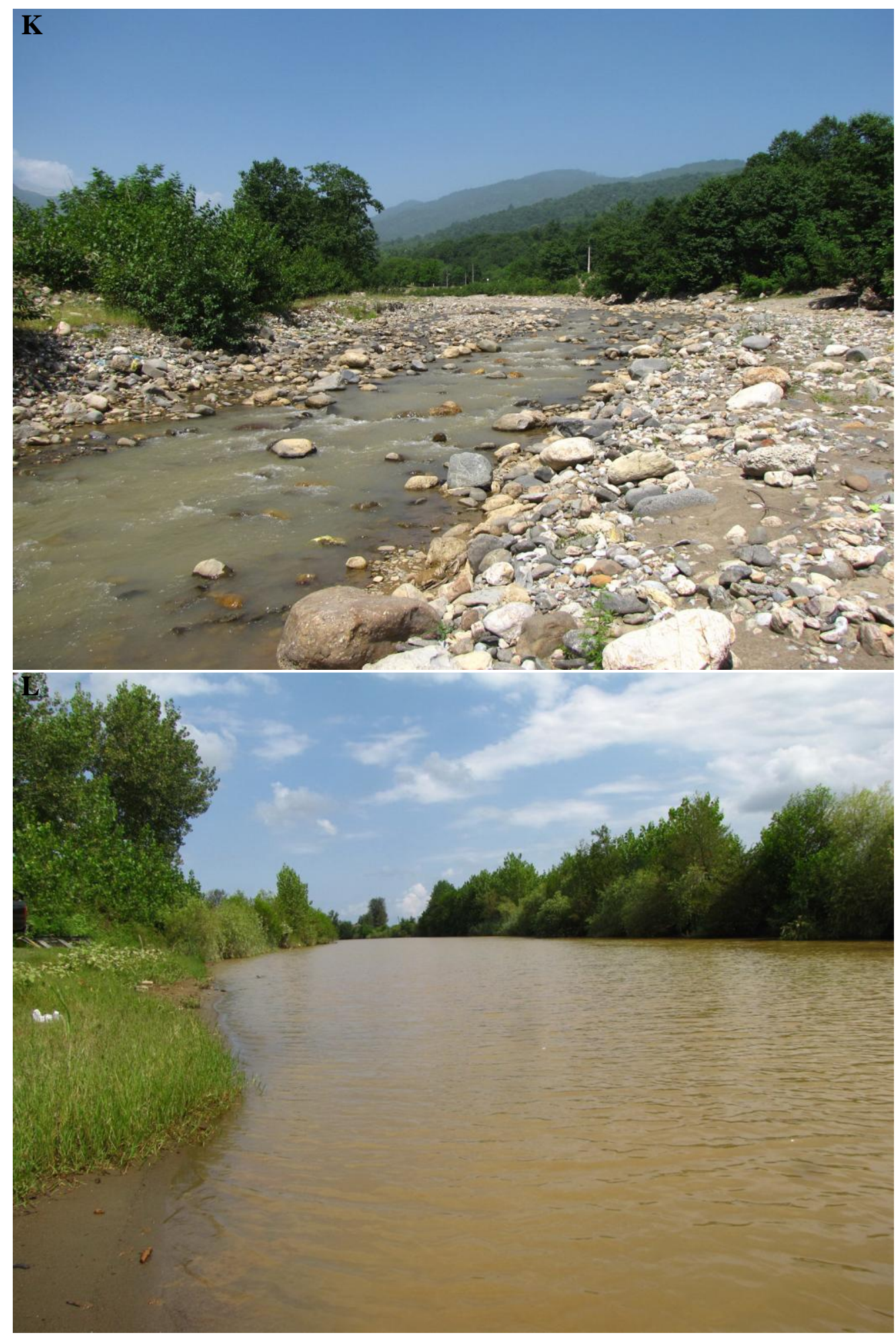

......continued on the next page 


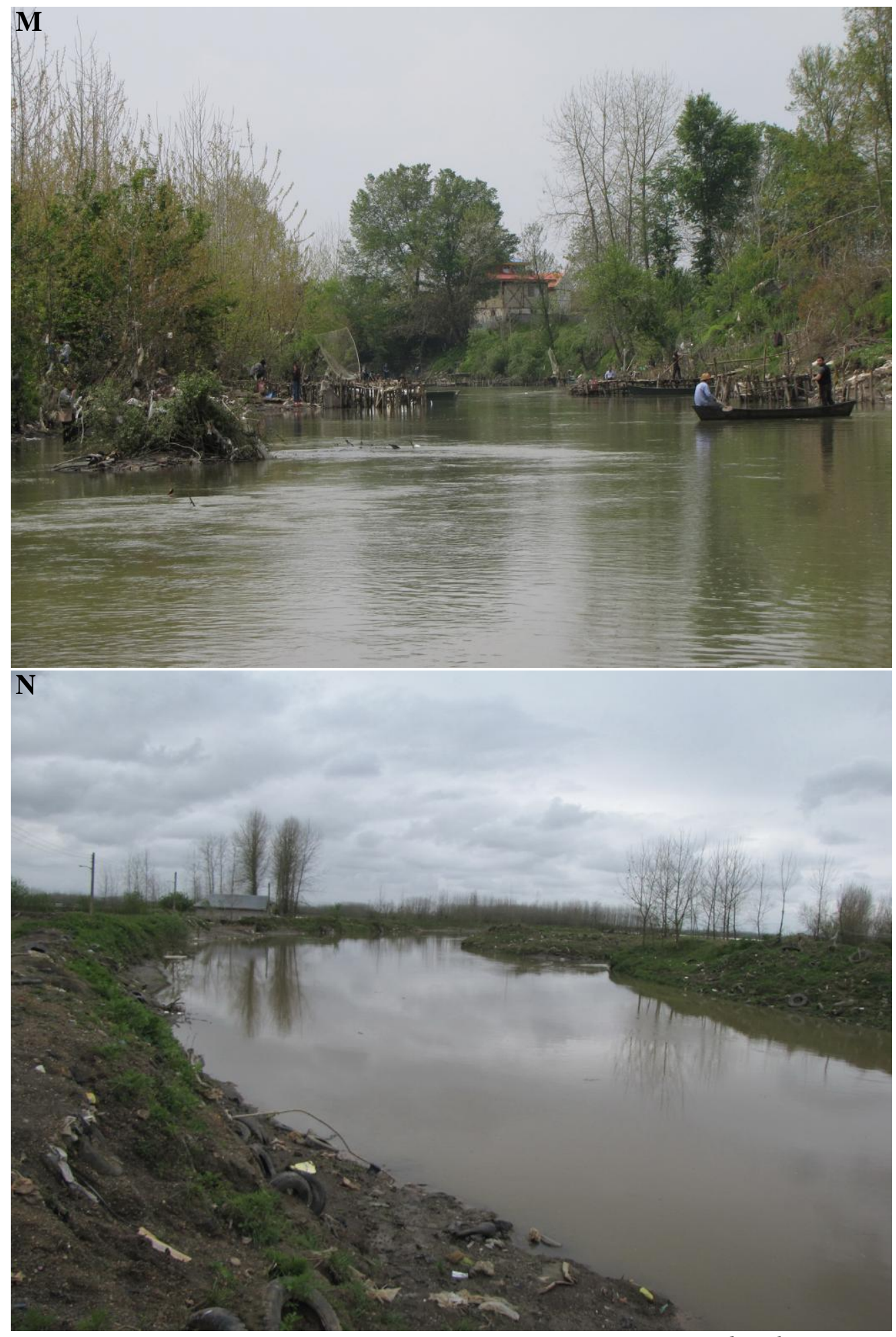

......continued on the next page 


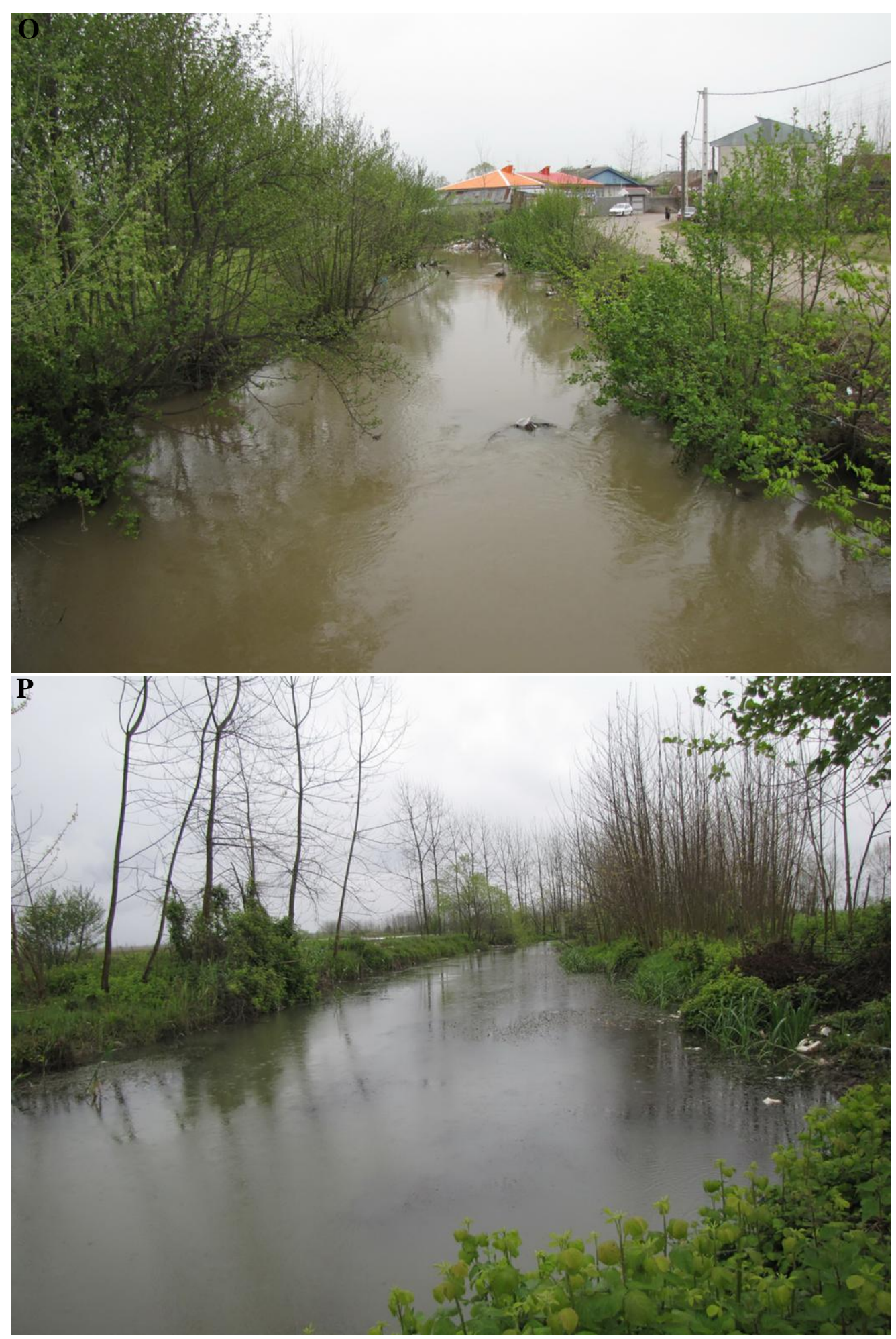


Appendix 2: Seventy two identified fish species in the Anzali Wetland basin. The order of appearance of species is in accordance with Table 1.

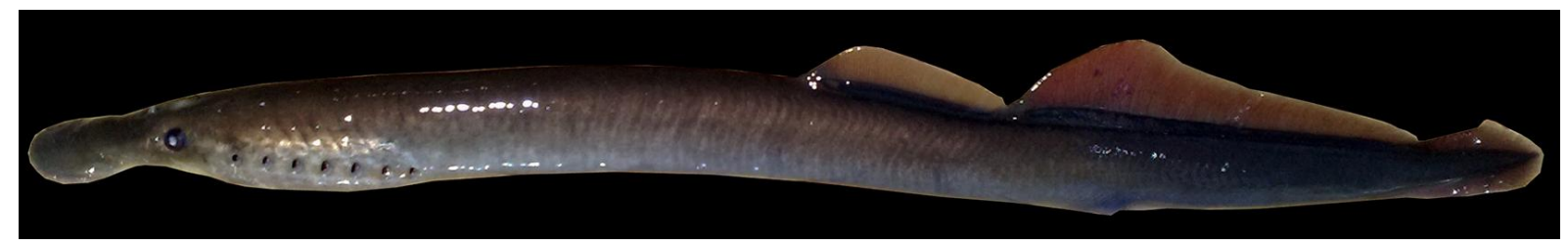

\section{Caspiomyzon wagneri}

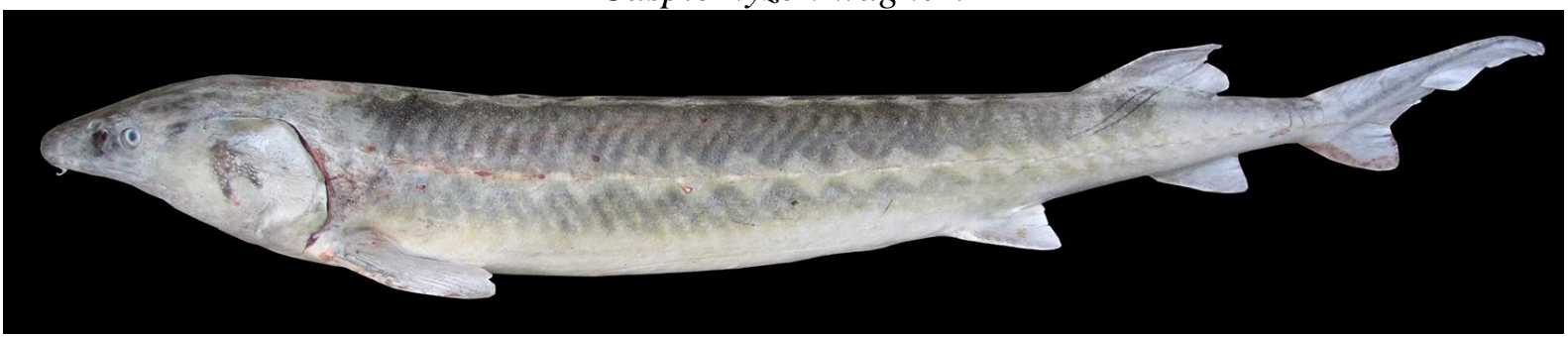

Acipenser persicus

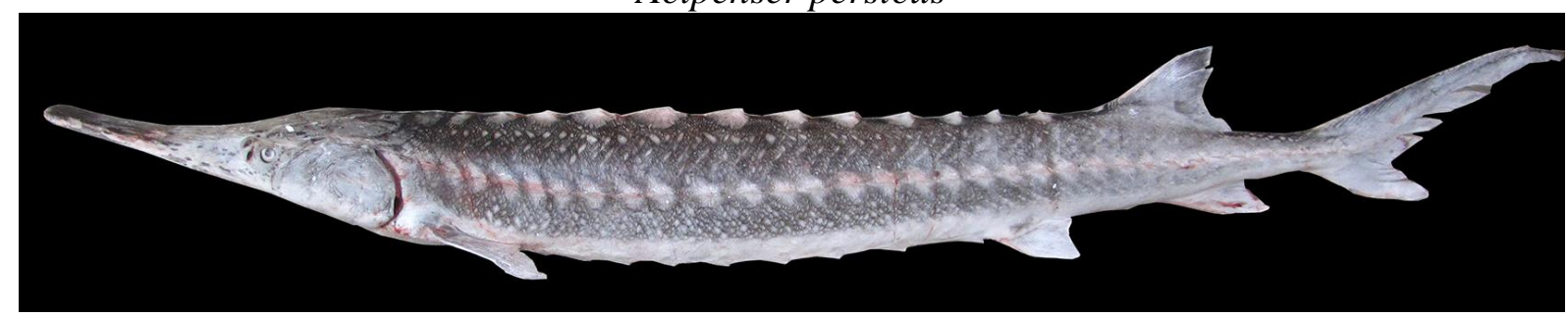

Acipenser stellatus

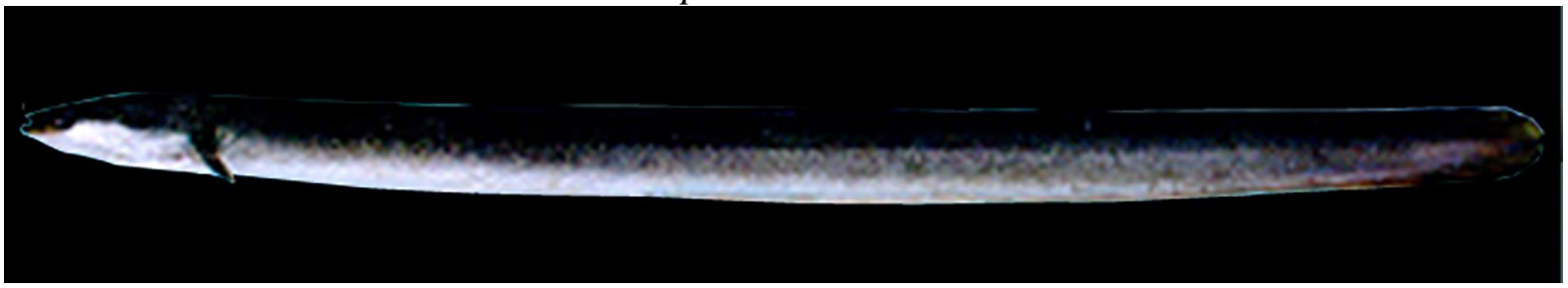

Anguilla anguilla

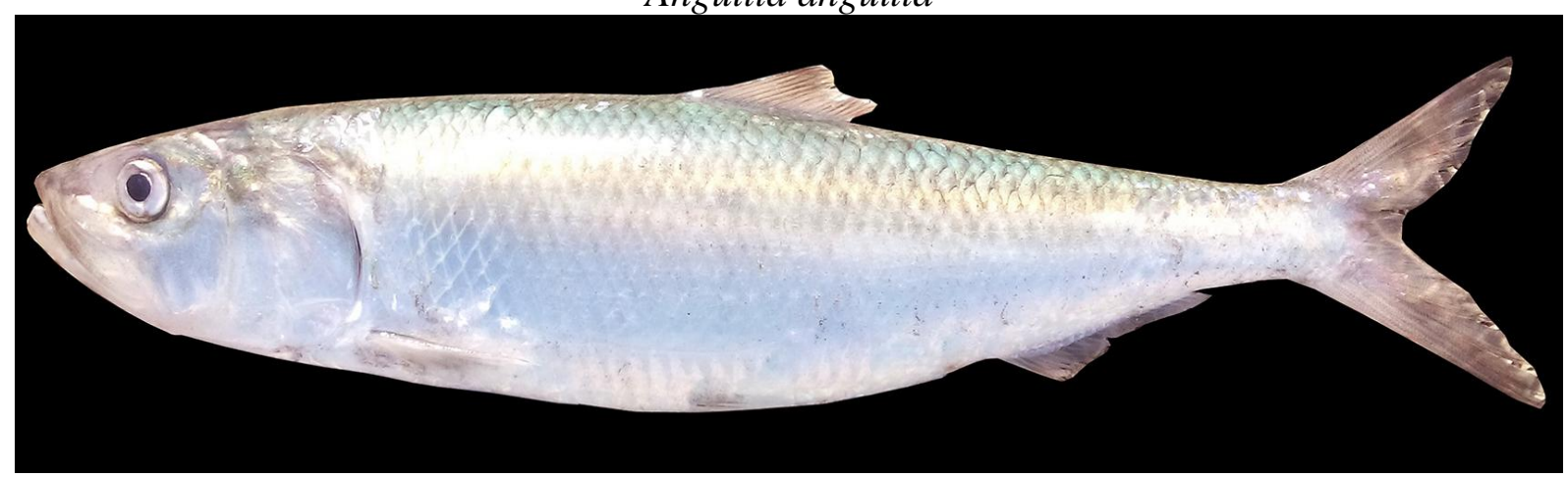

Alosa braschnikowi

......continued on the next page 

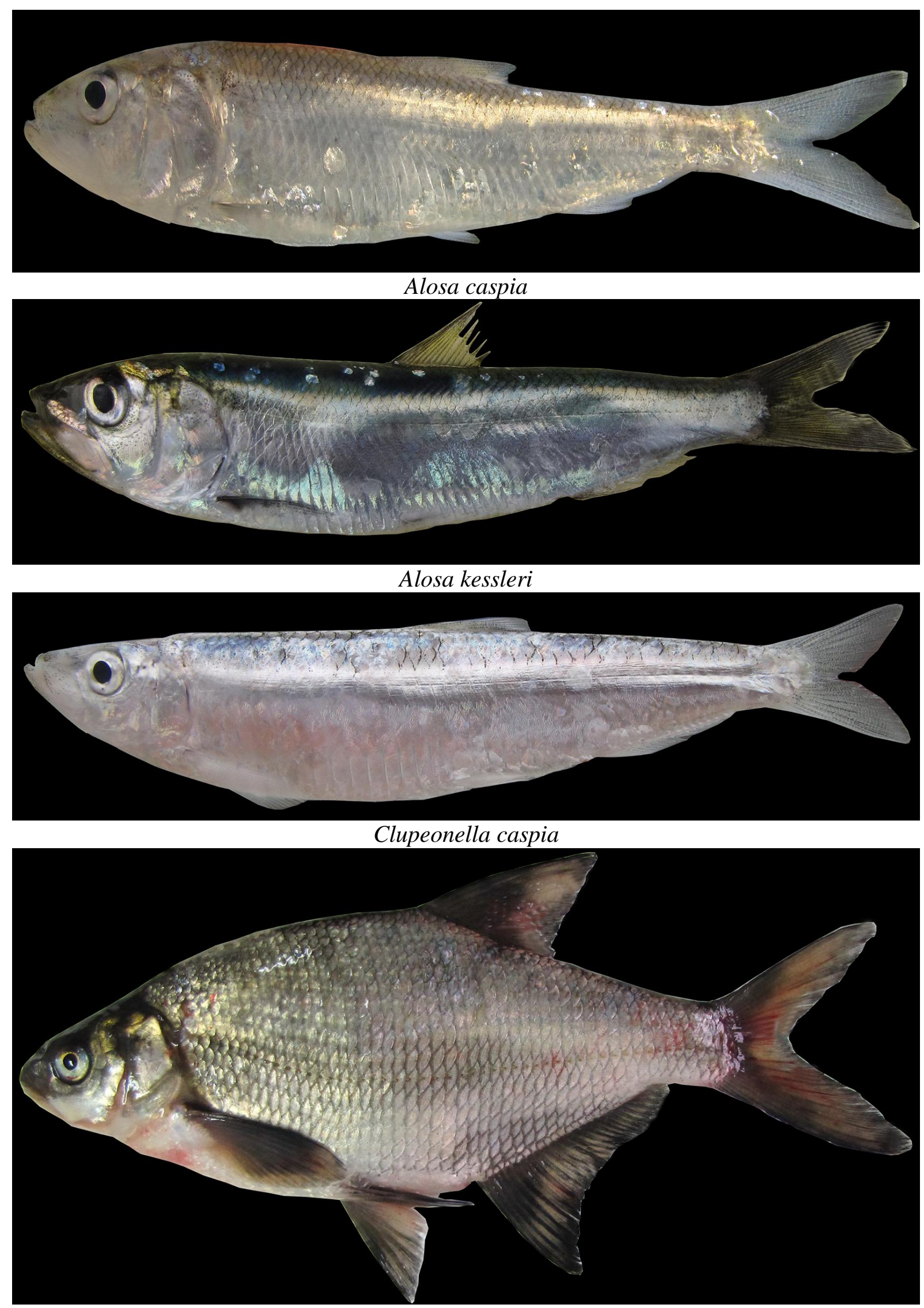

Abramis brama

......continued on the next page 


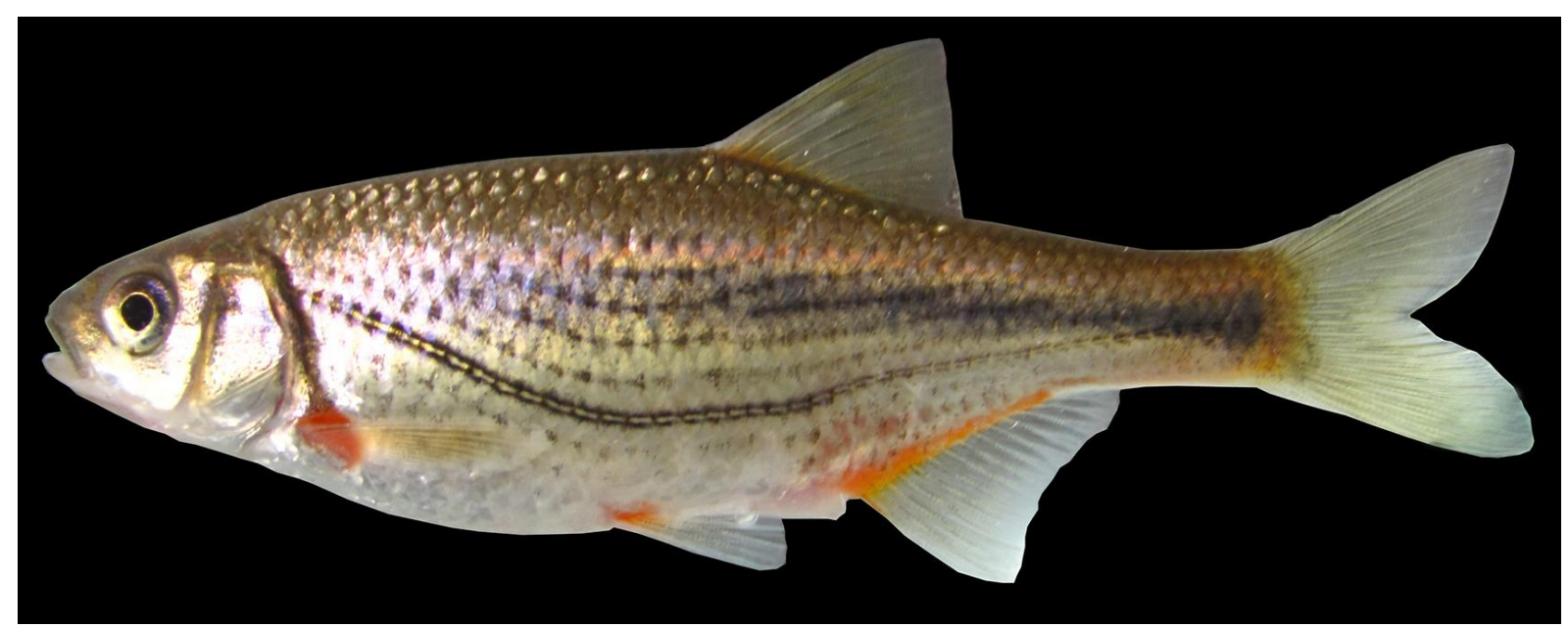

Alburnoides samiii

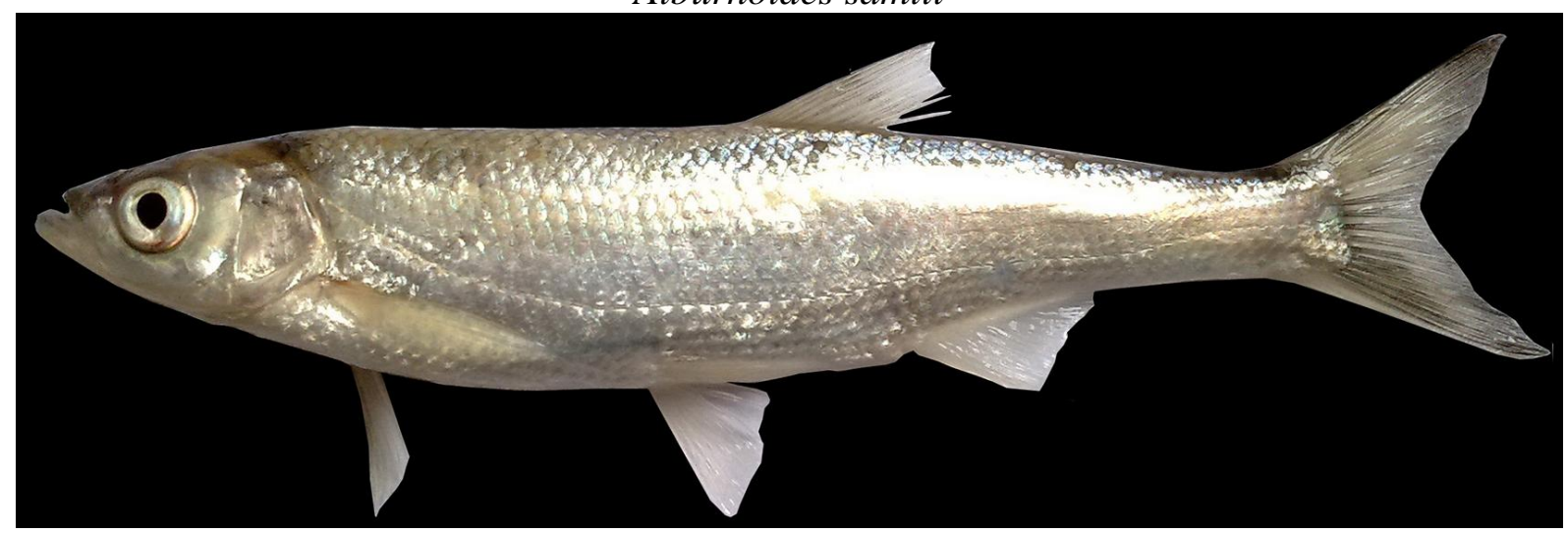

Alburnus chalcoides

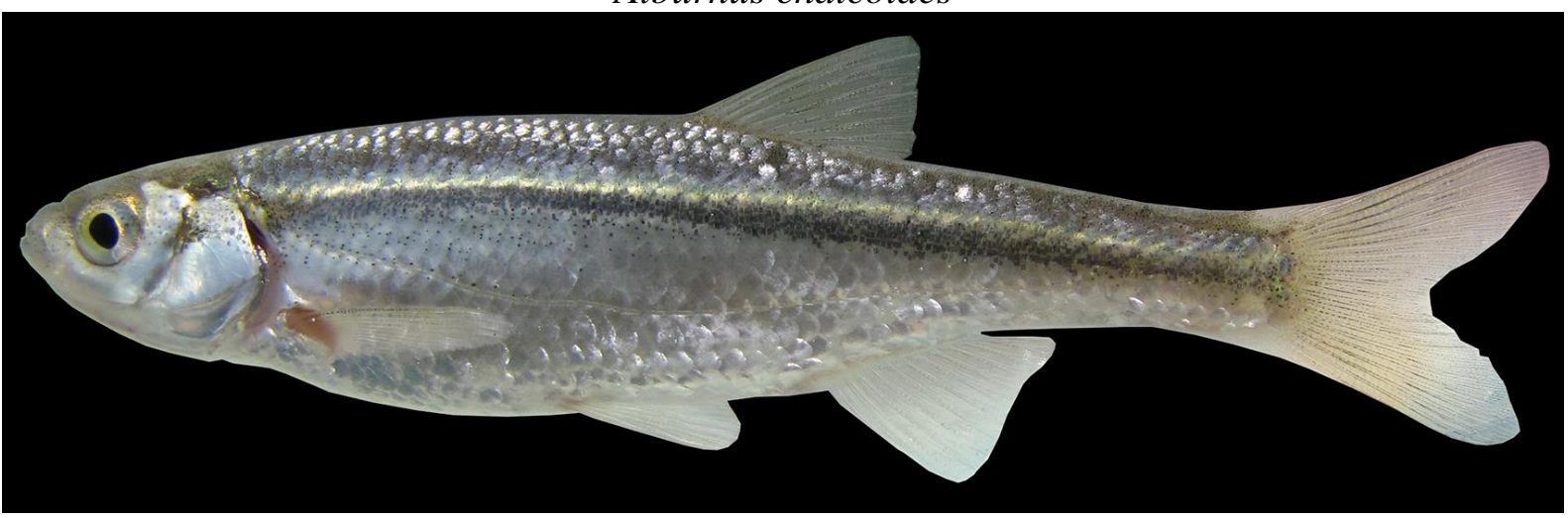

Alburnus filippi

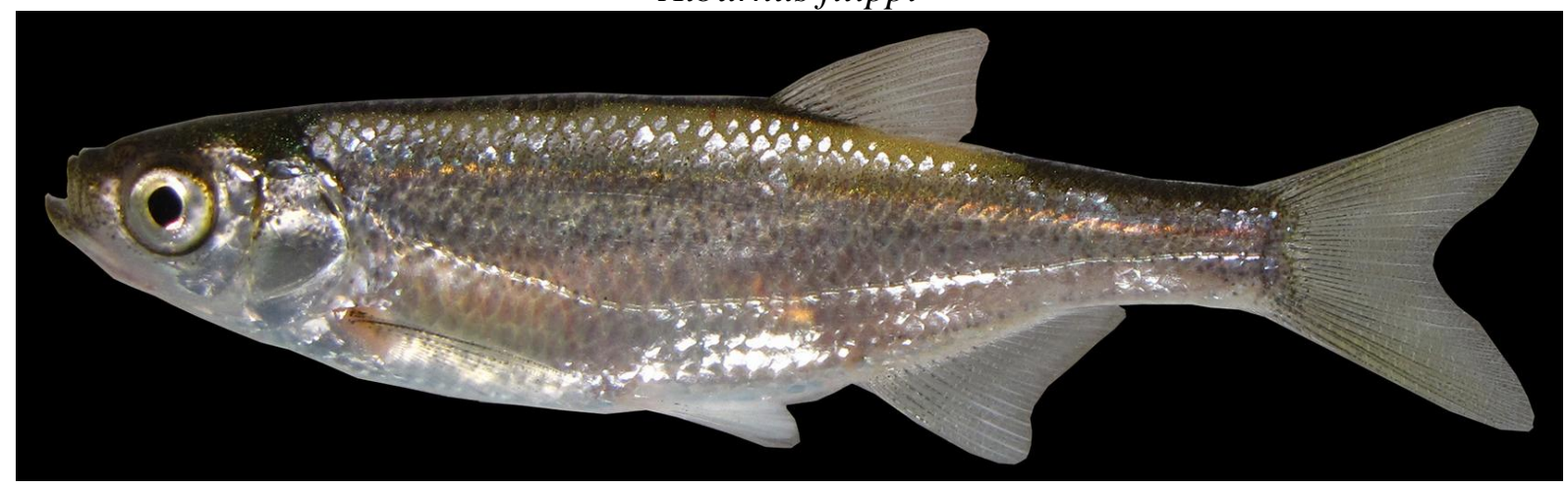

Alburnus hohenackeri

......continued on the next page 


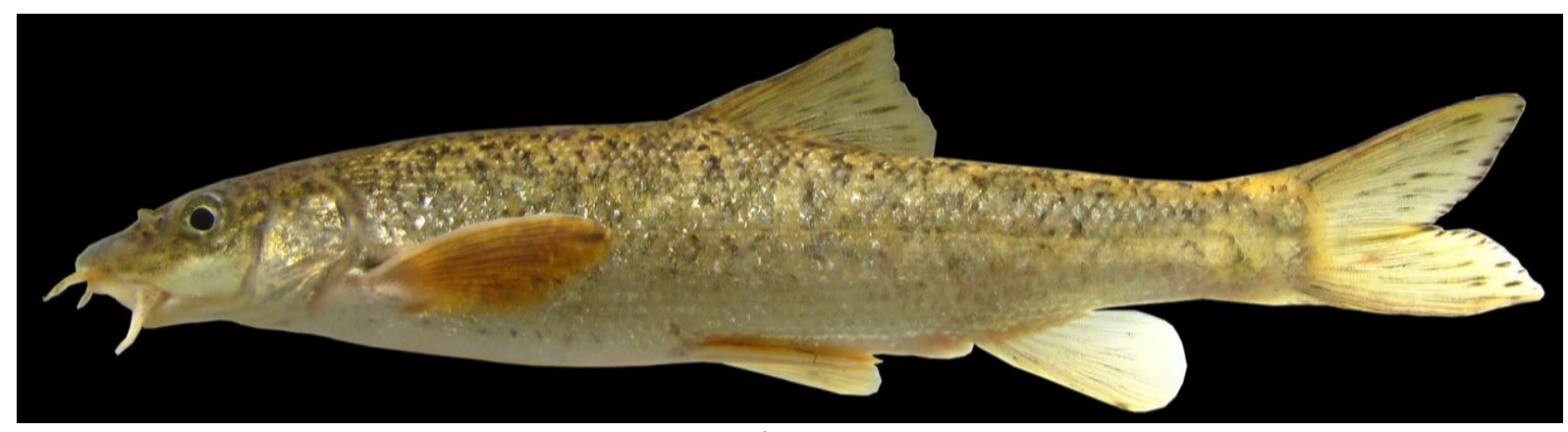

\section{Barbus cyri}

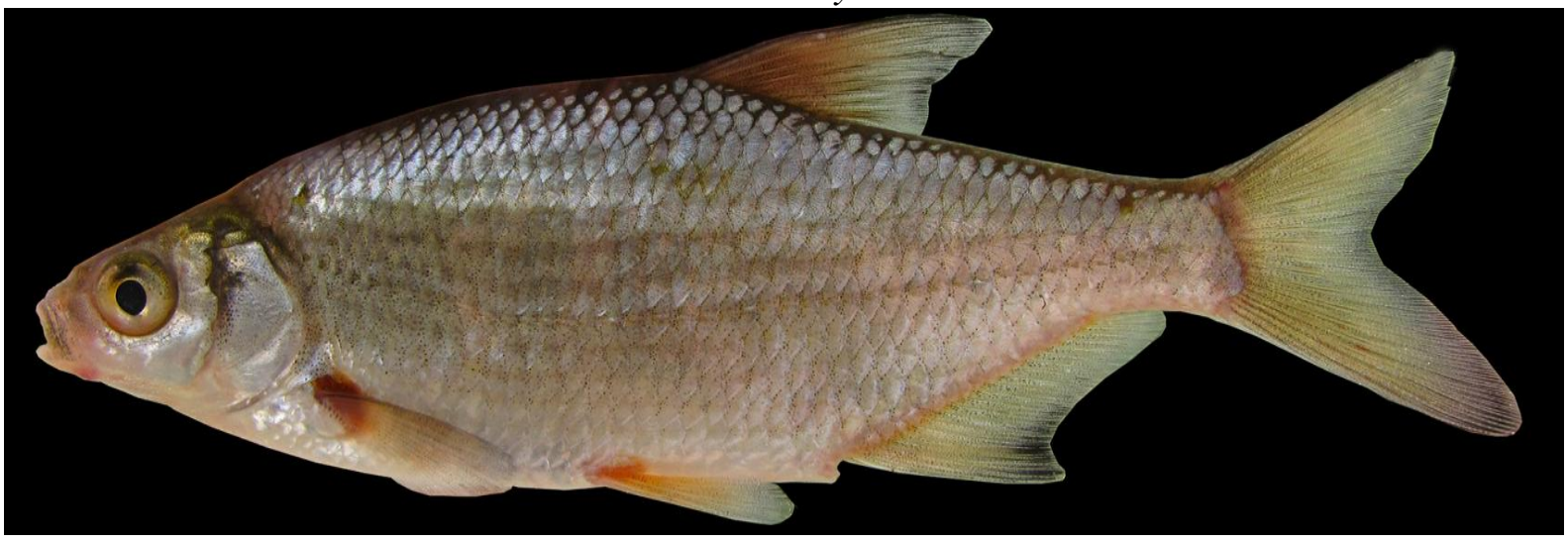

Blicca bjoerkna

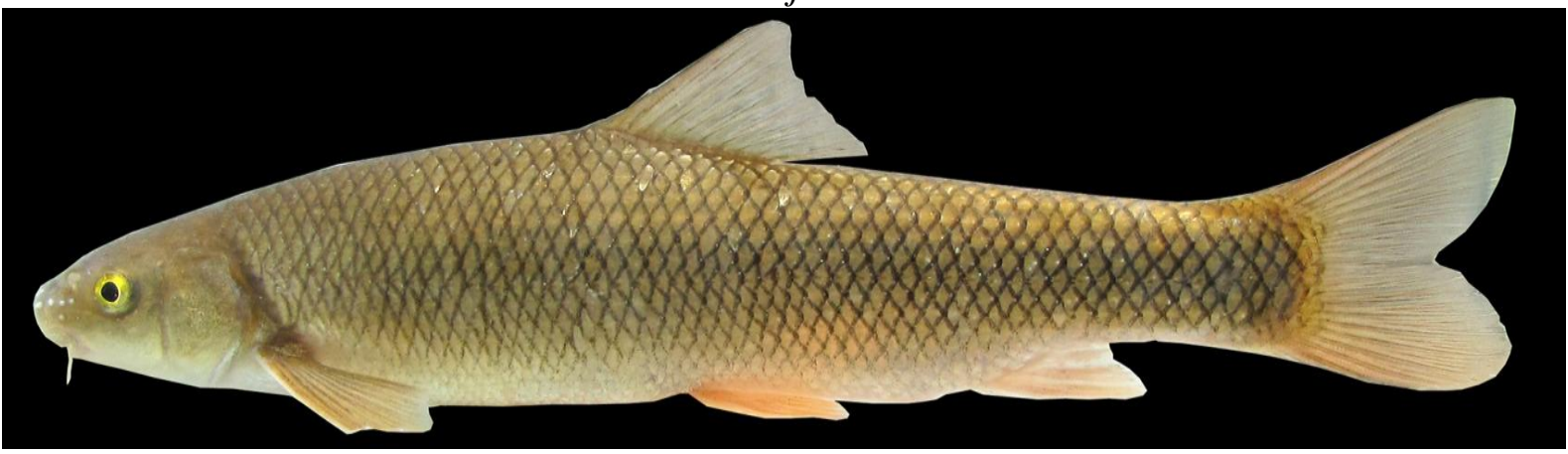

Capoeta razii

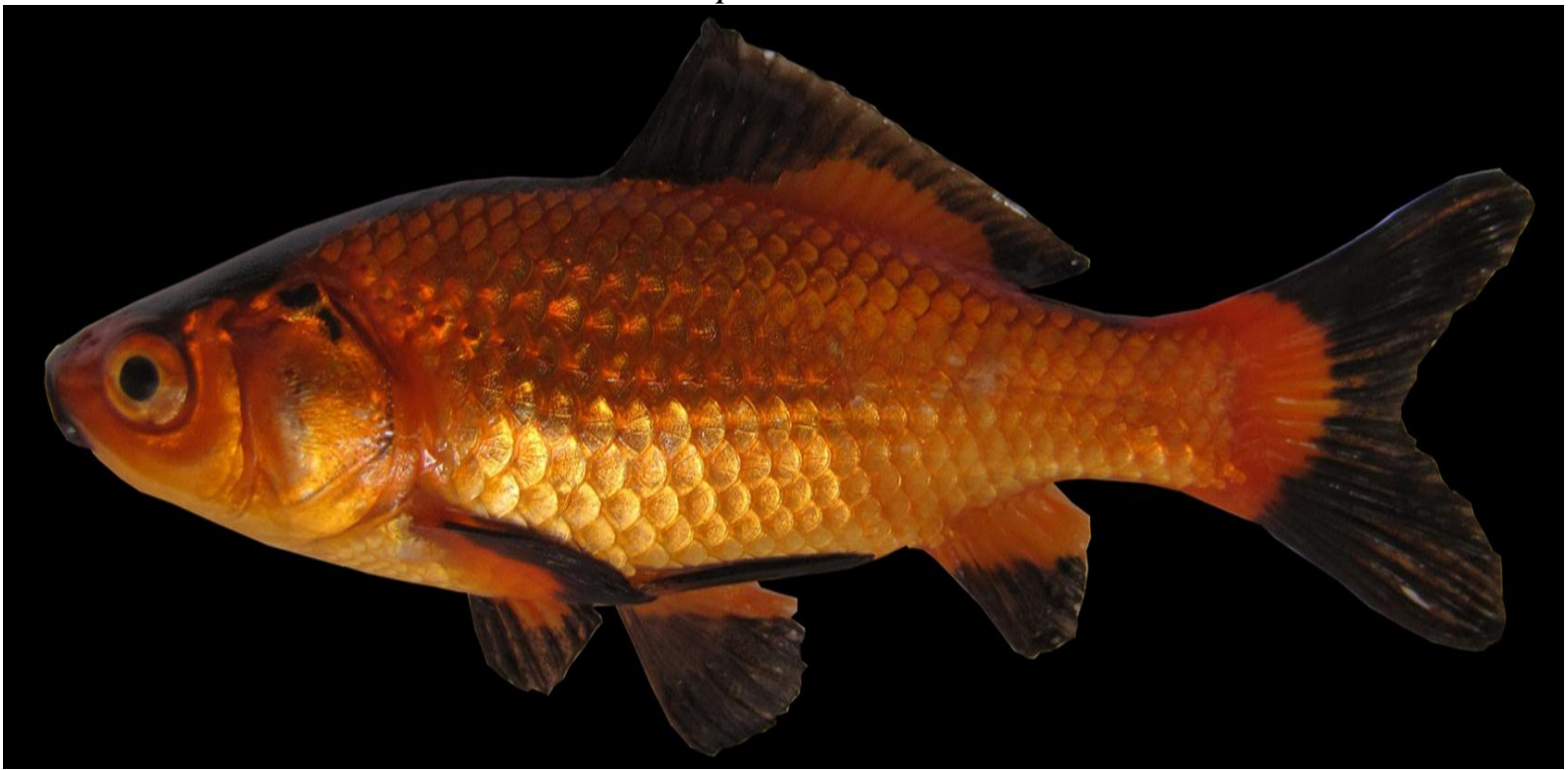

Carassius auratus 


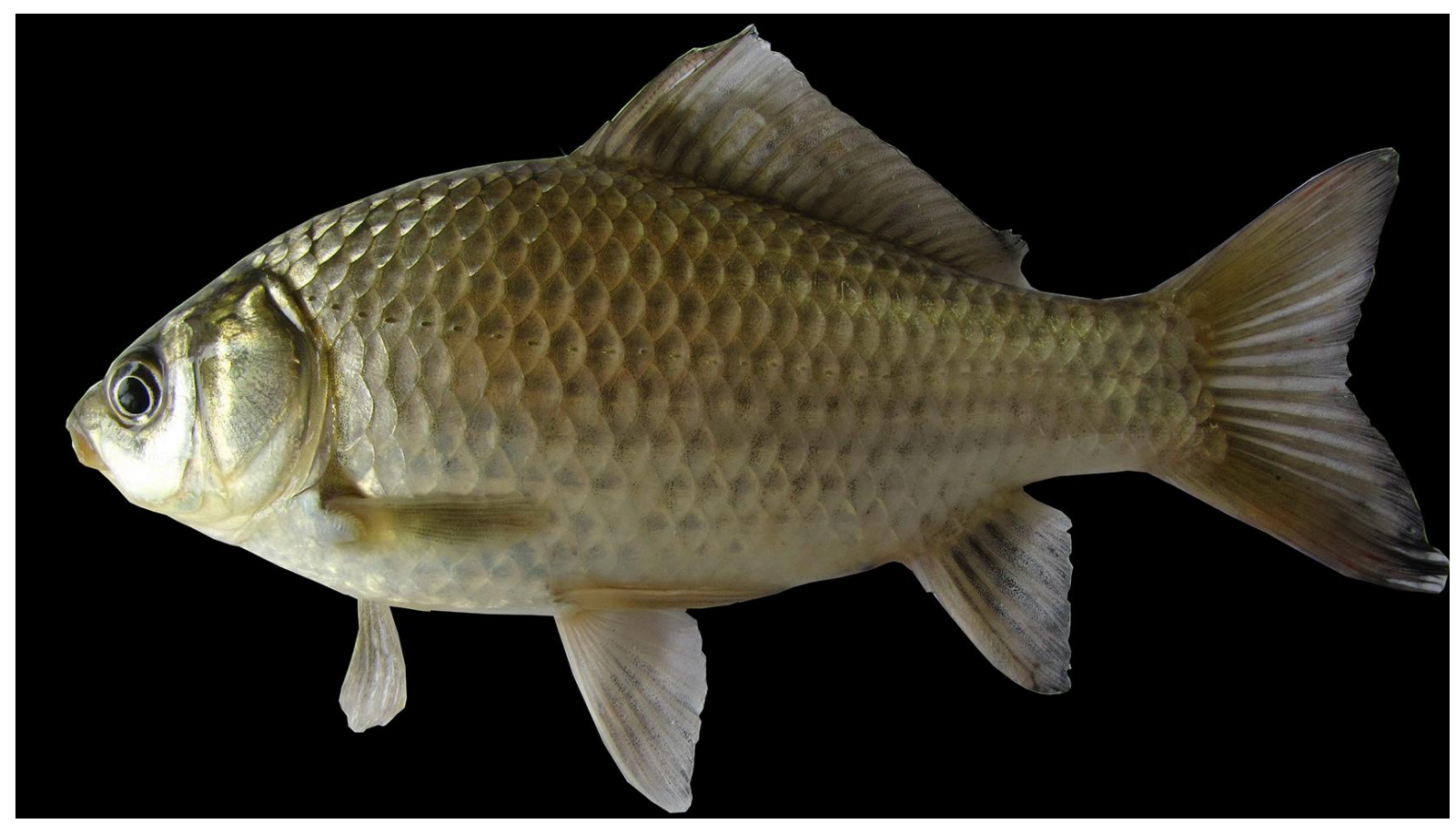

Carassius gibelio

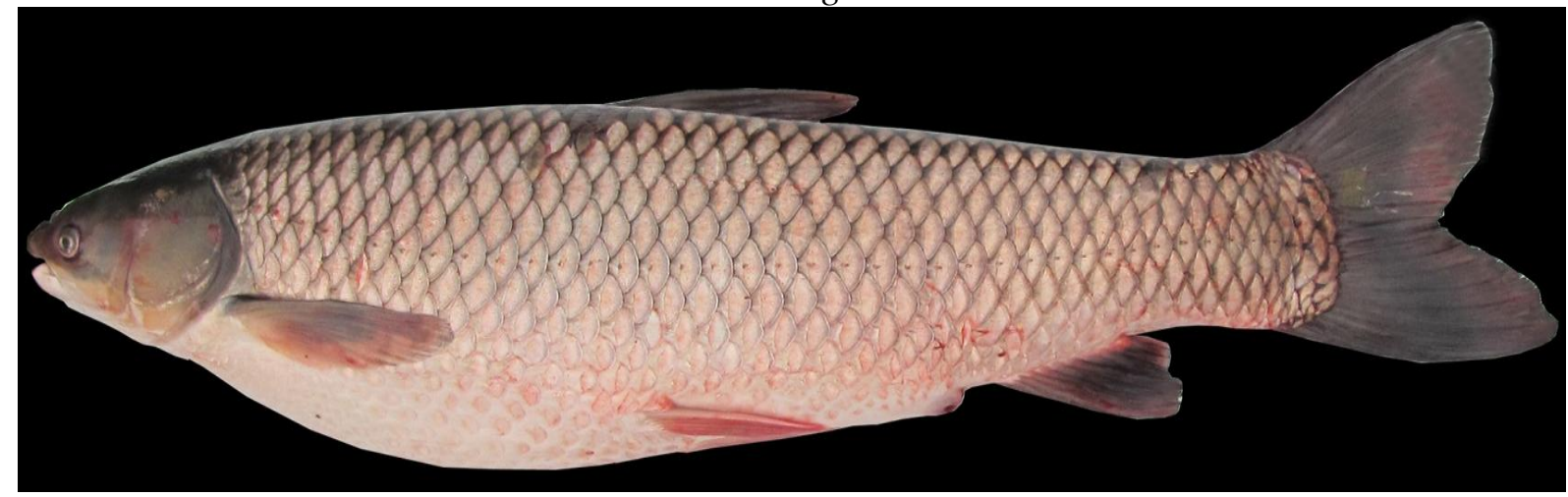

\section{Ctenopharyngodon idella}

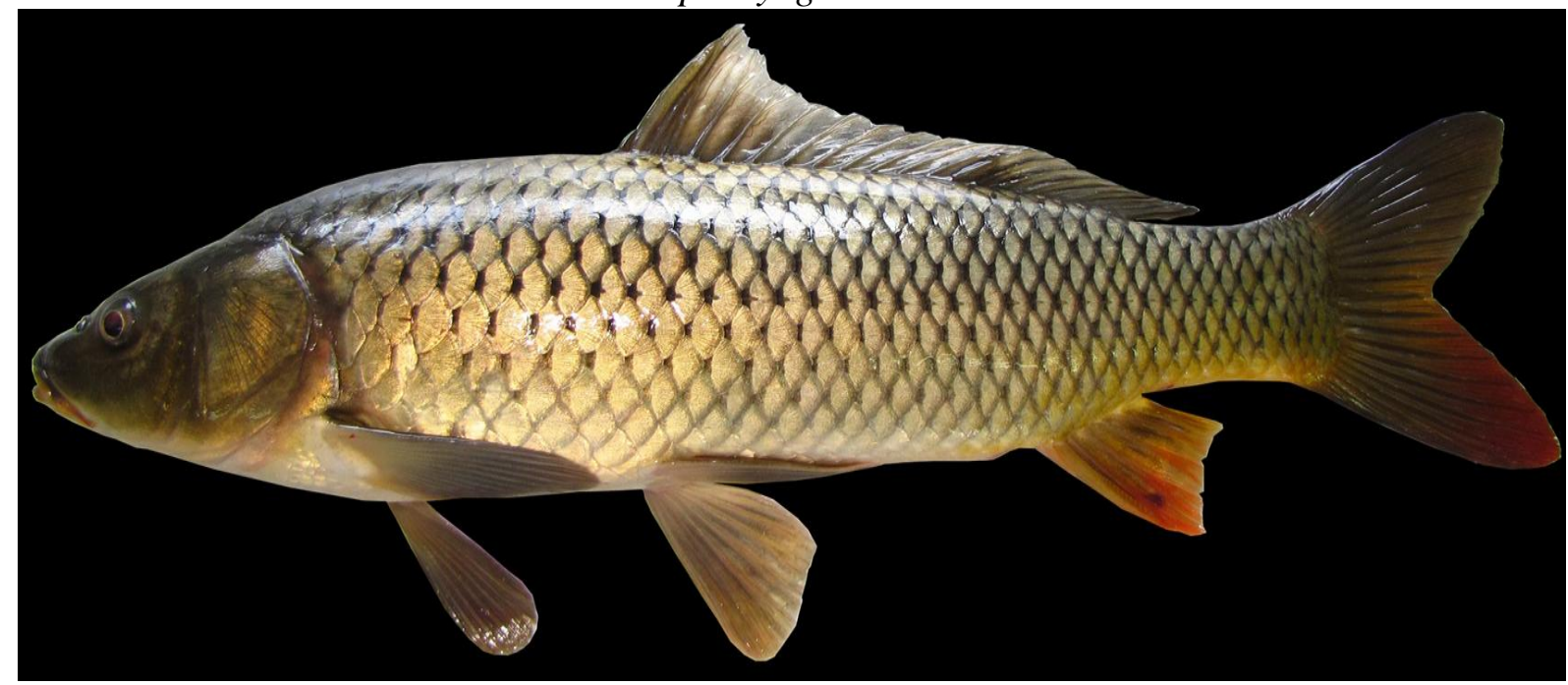

Cyprinus carpio

......continued on the next page 


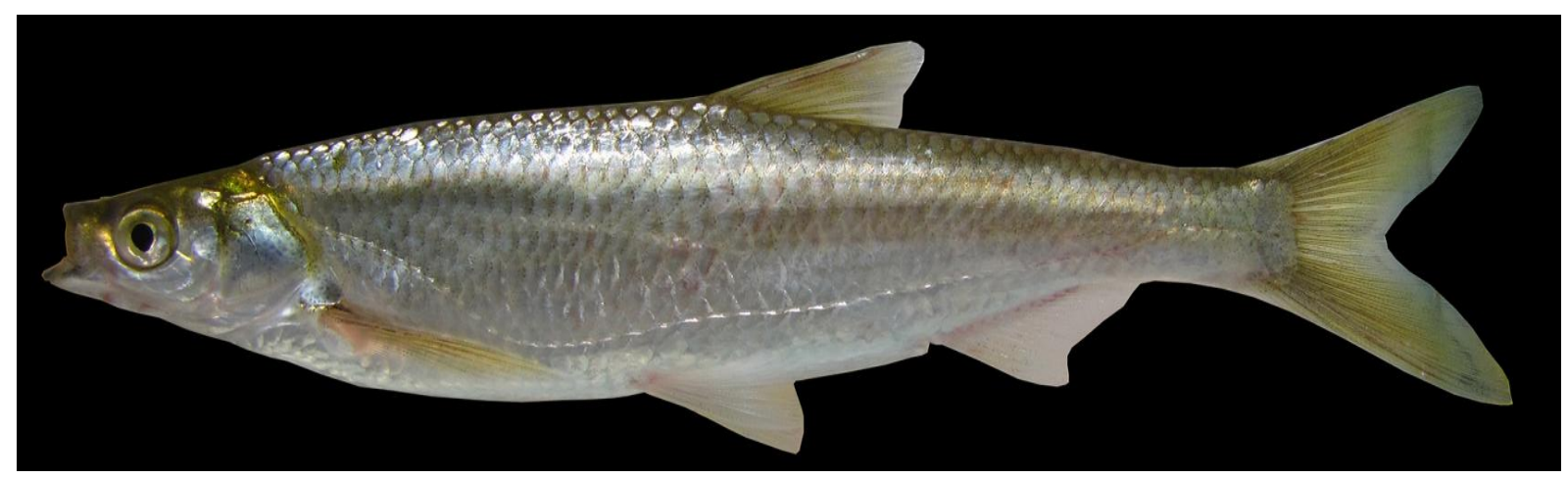

\section{Hemiculter leucisculus}

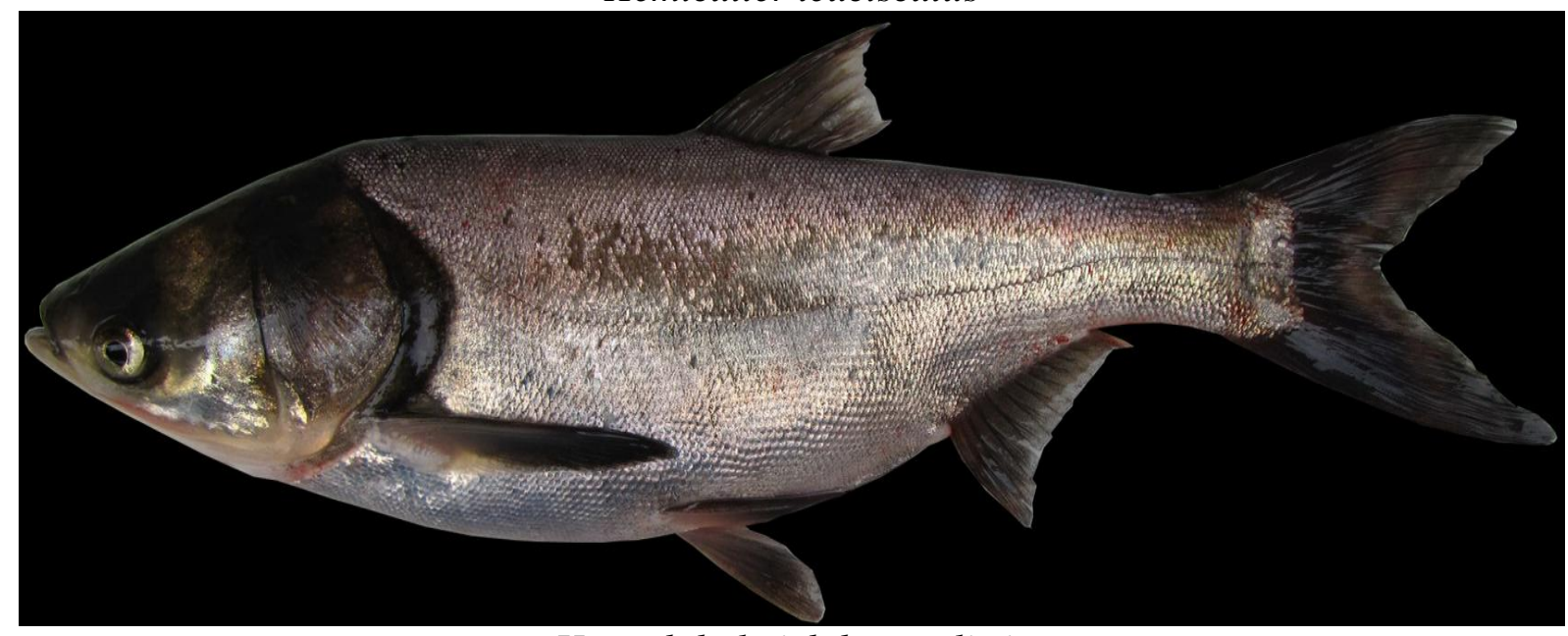

\section{Hypophthalmichthys molitrix}

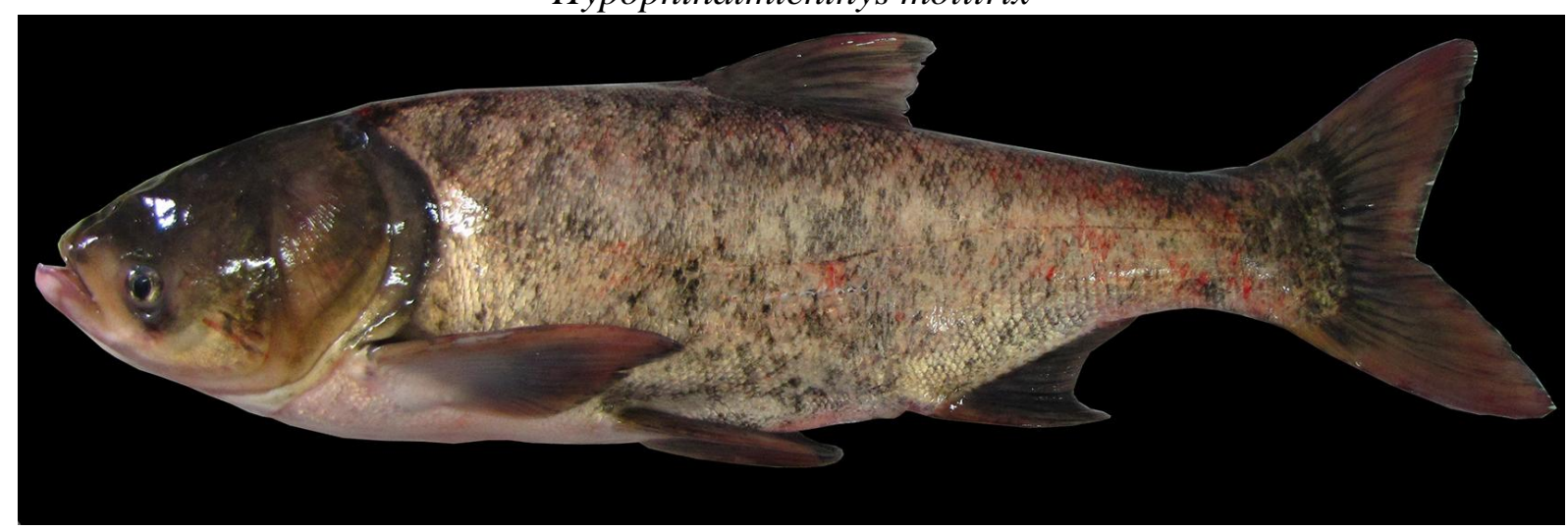

Hypophthalmichthys nobilis

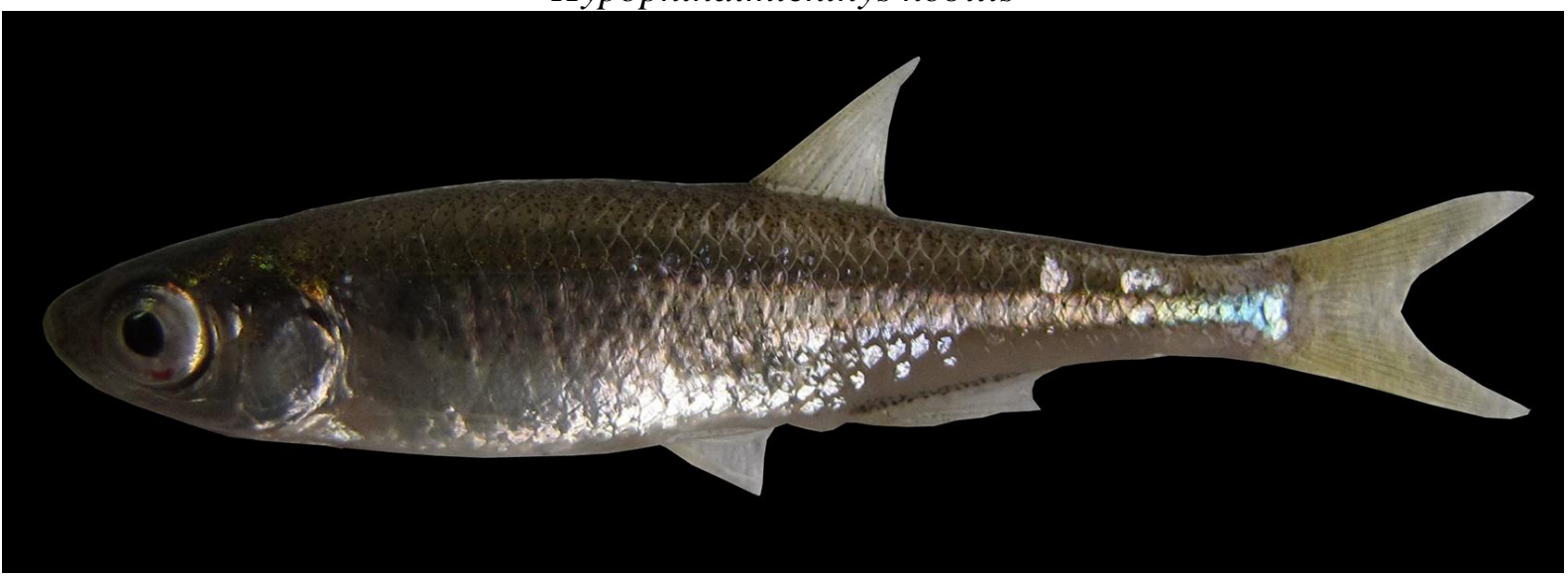

Leucaspius delineatus 


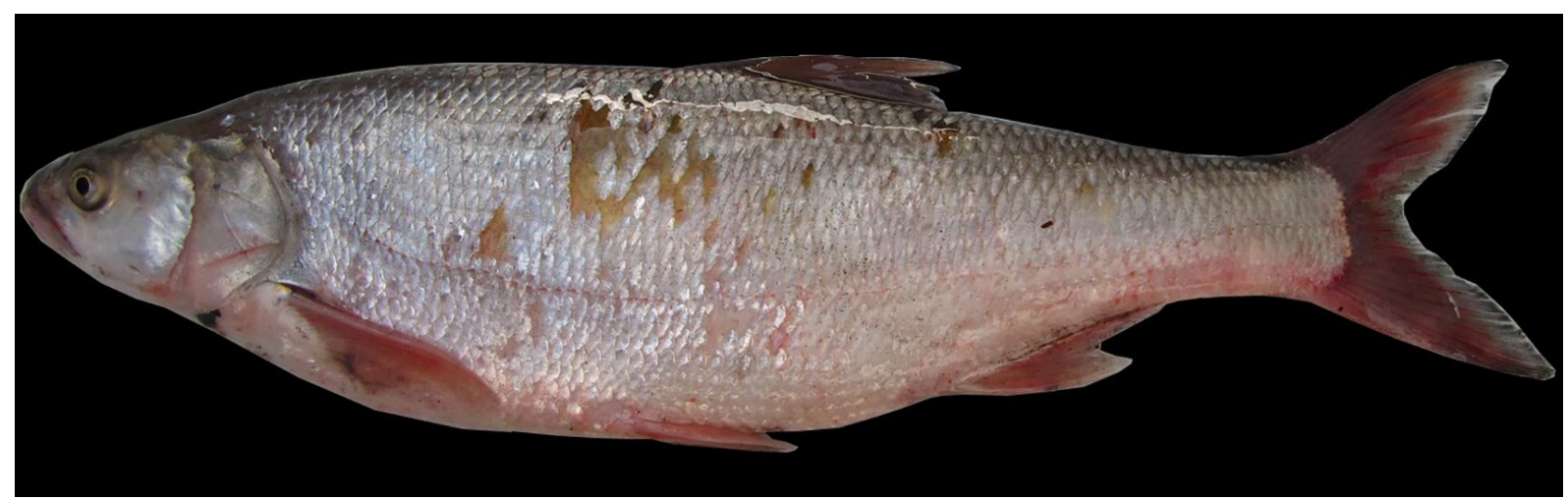

\section{Leuciscus aspius}
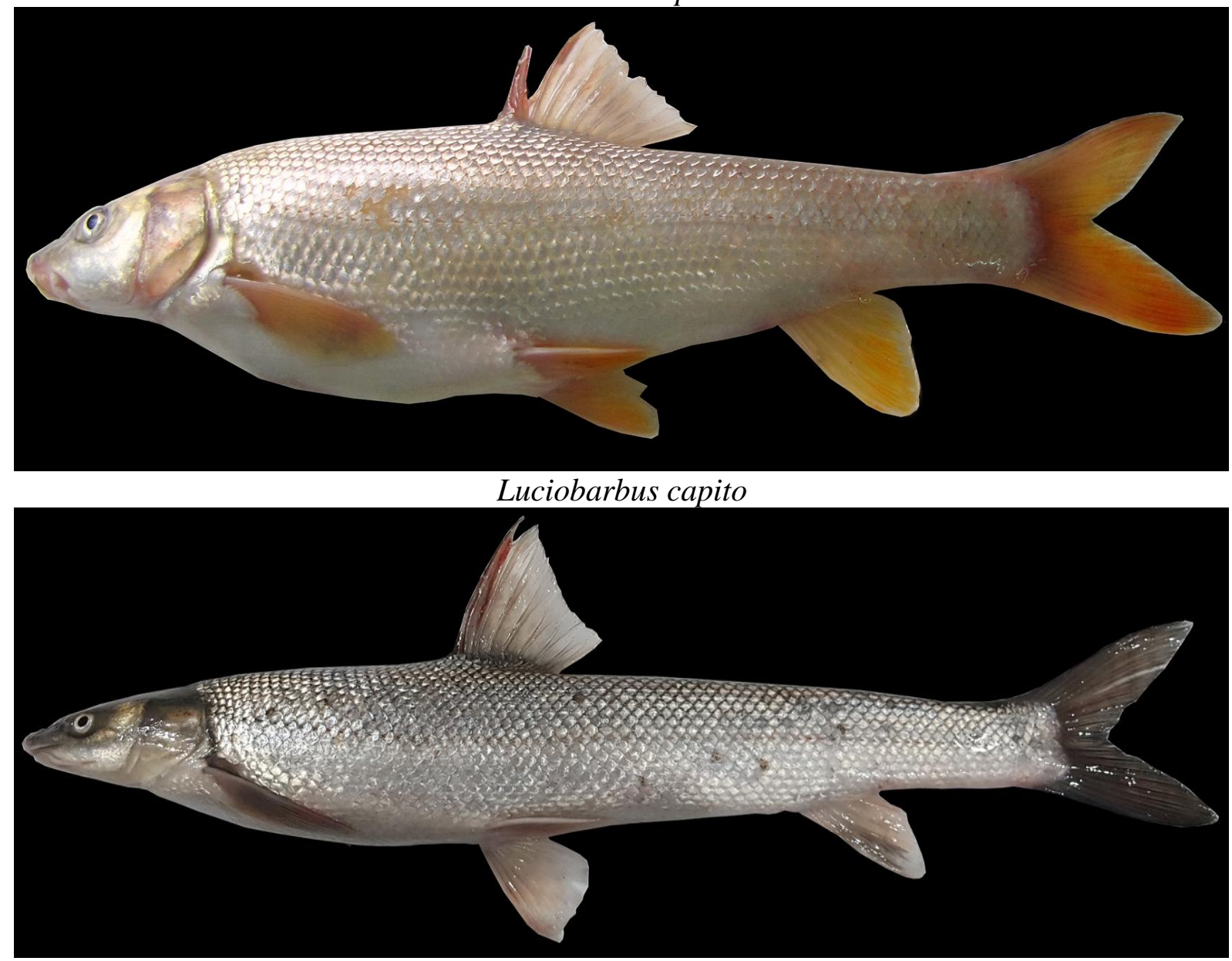

\section{Luciobarbus caspius}

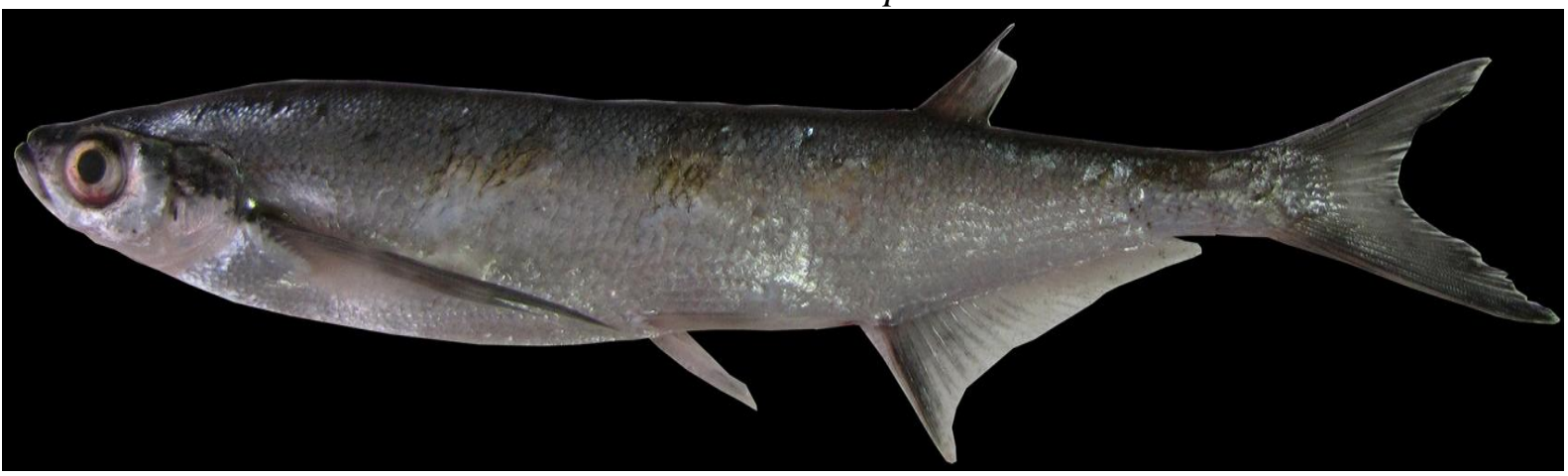

Pelecus cultratus

......continued on the next page 

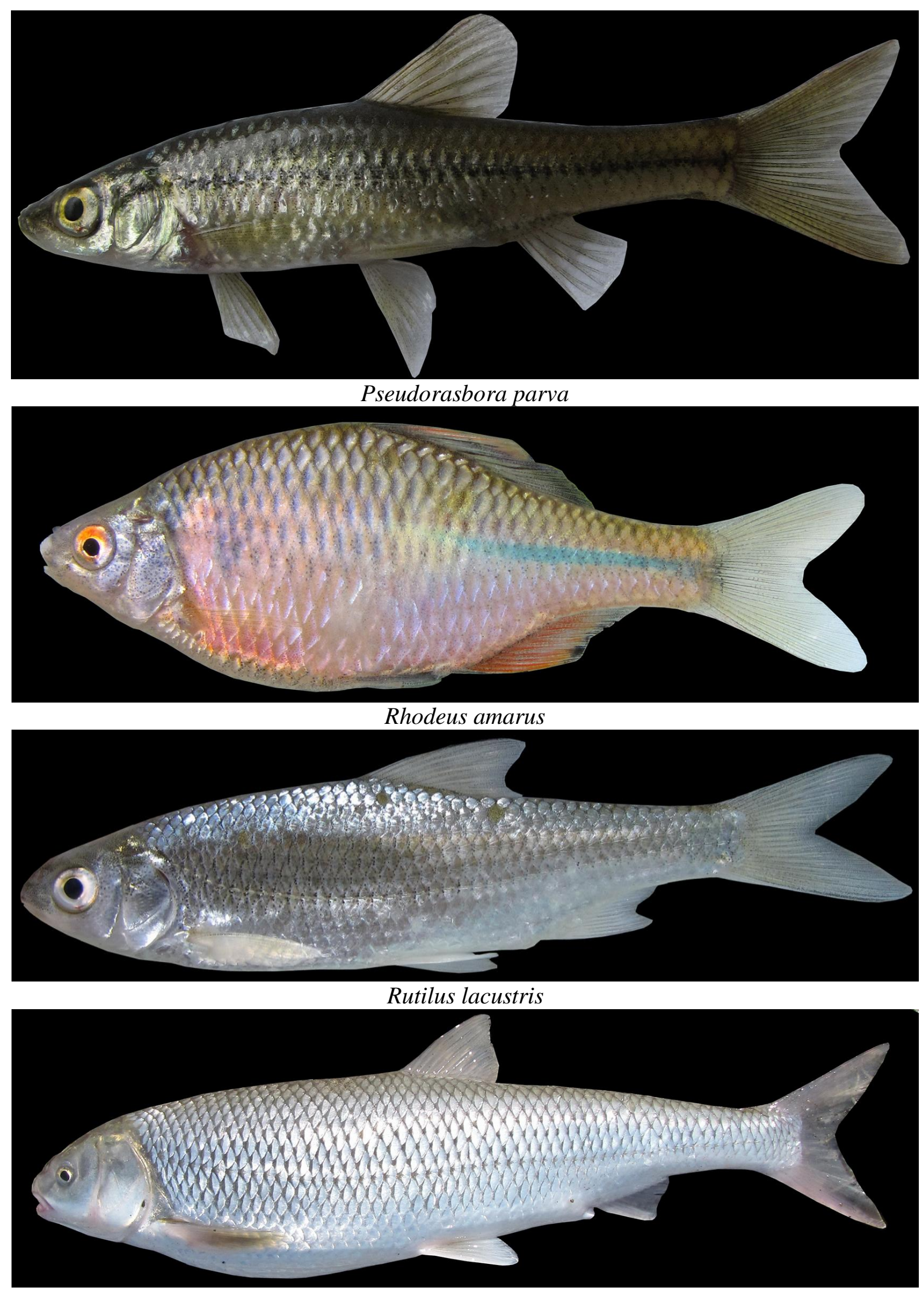

Rutilus kutum

......continued on the next page 


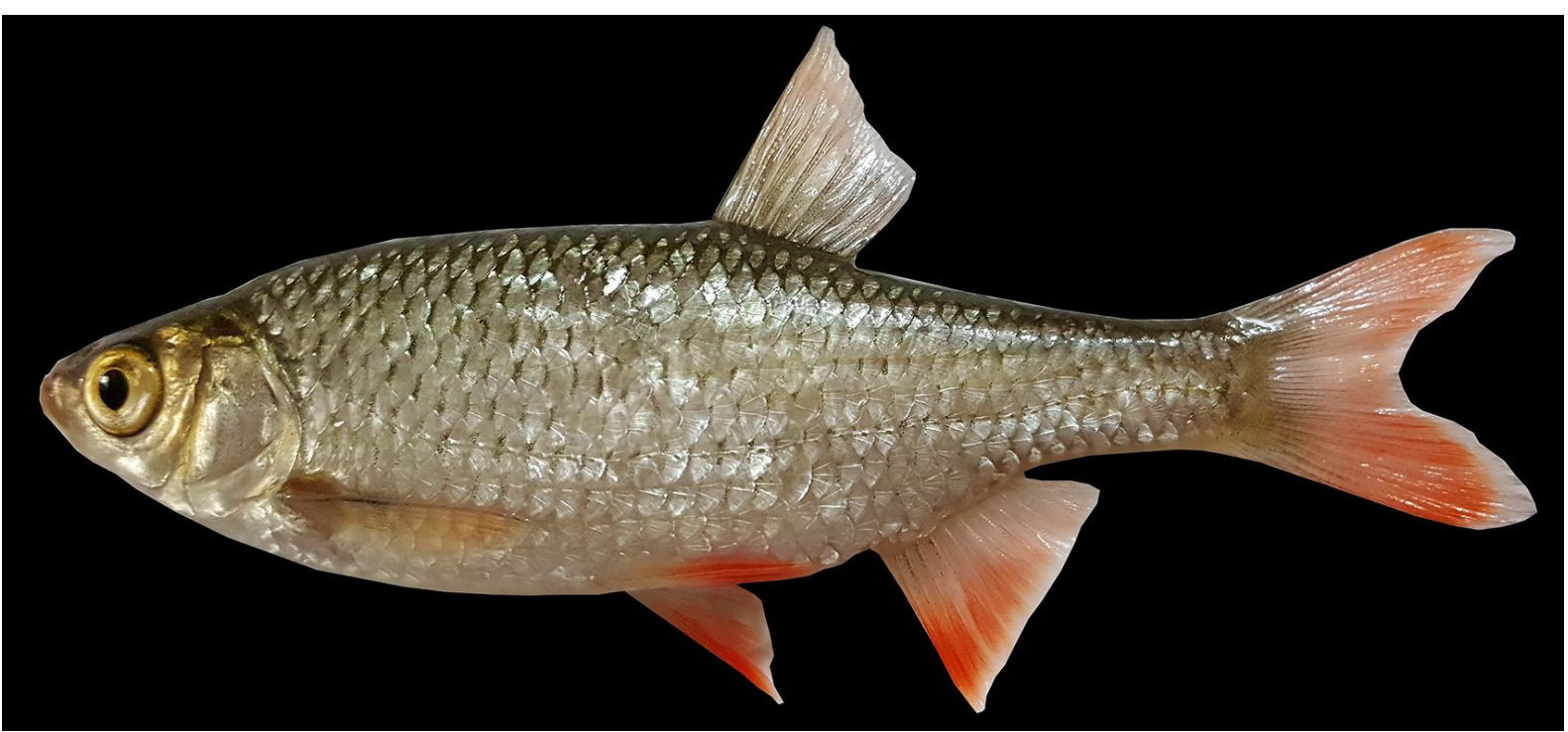

\section{Scardinius erythrophthalmus}

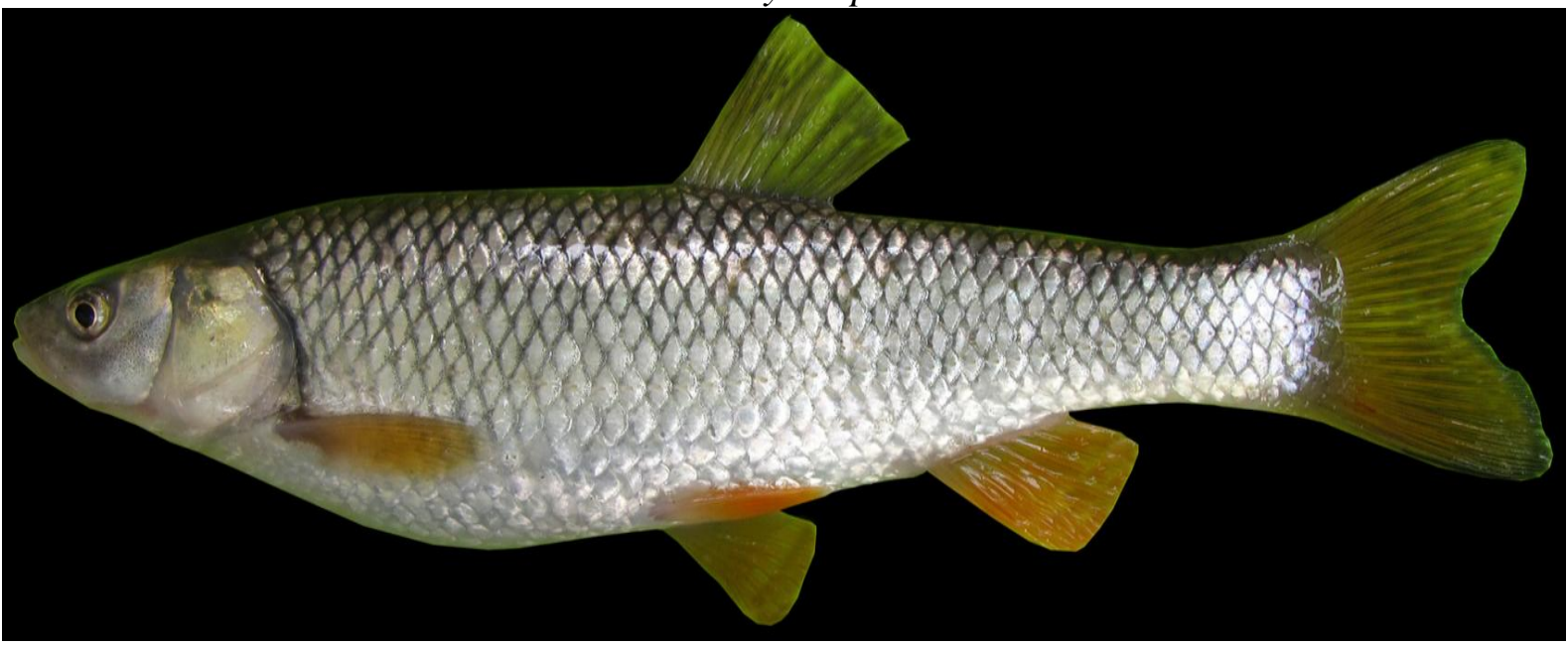

Squalius turcicus

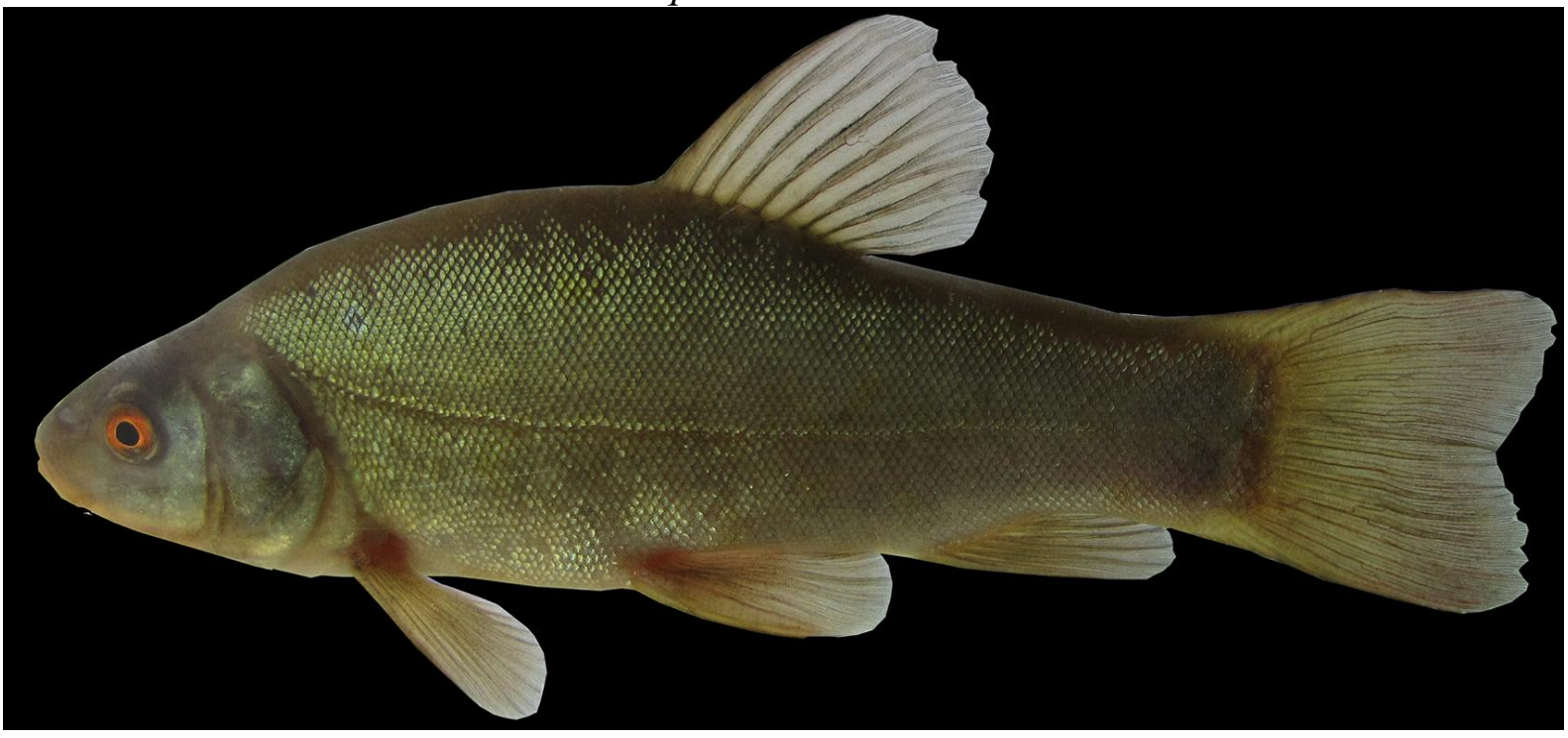

Tinca tinca

......continued on the next page 


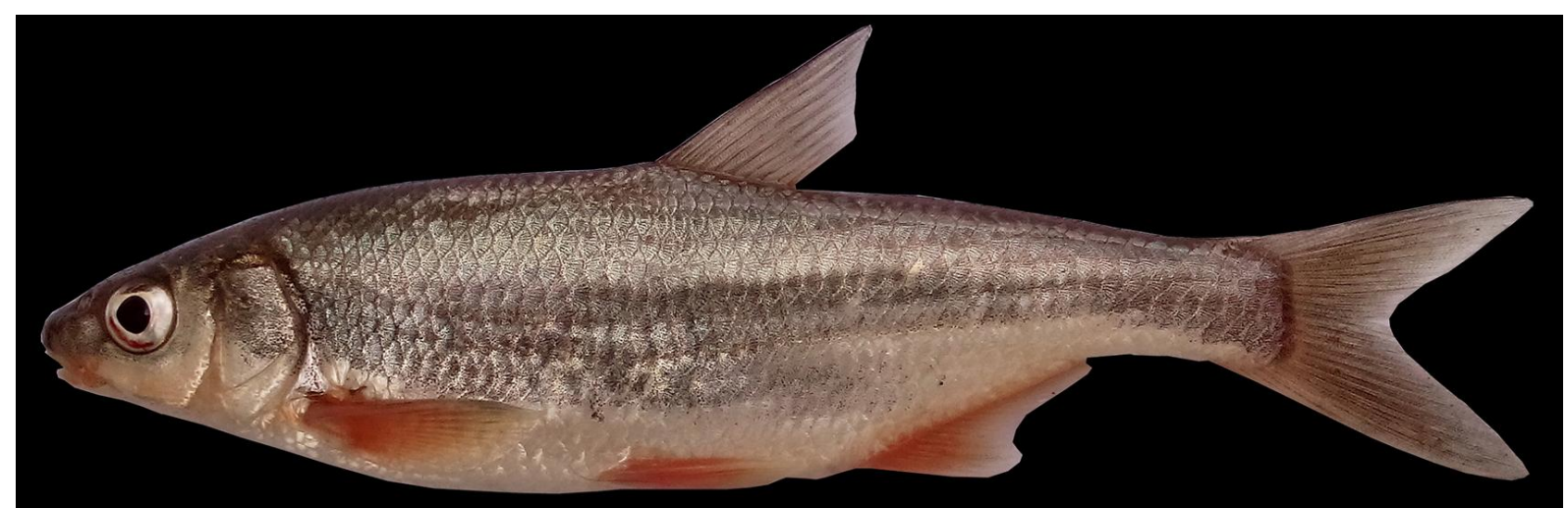

\section{Vimba persa}

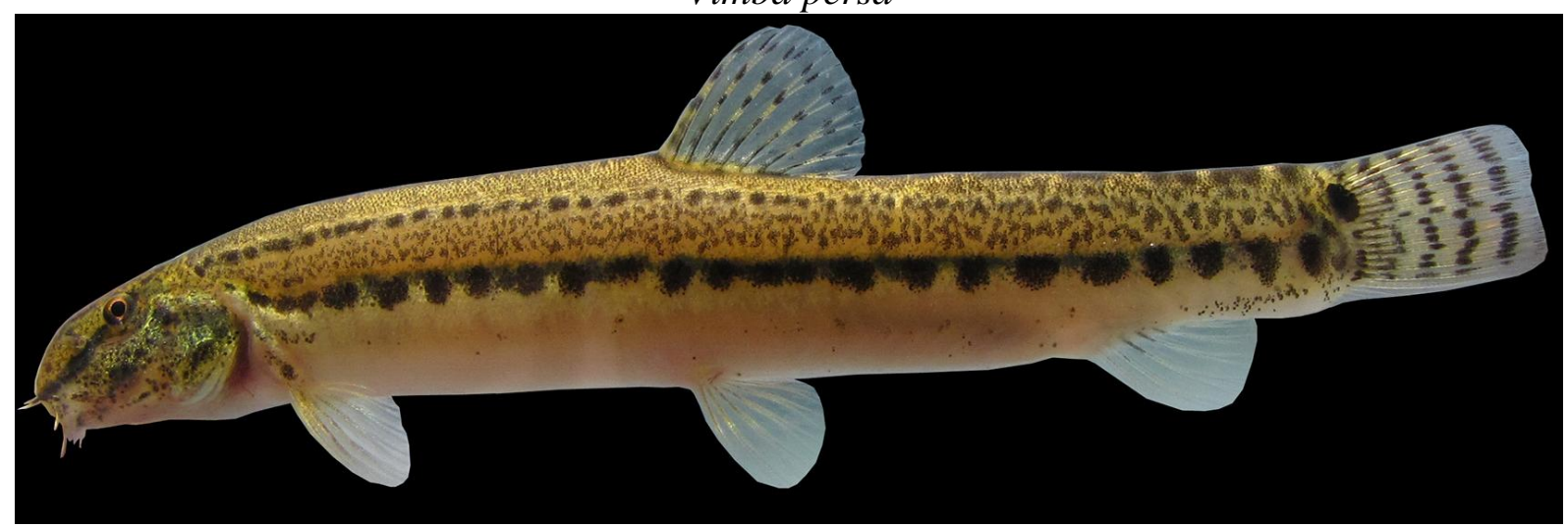

\section{Cobitis saniae}

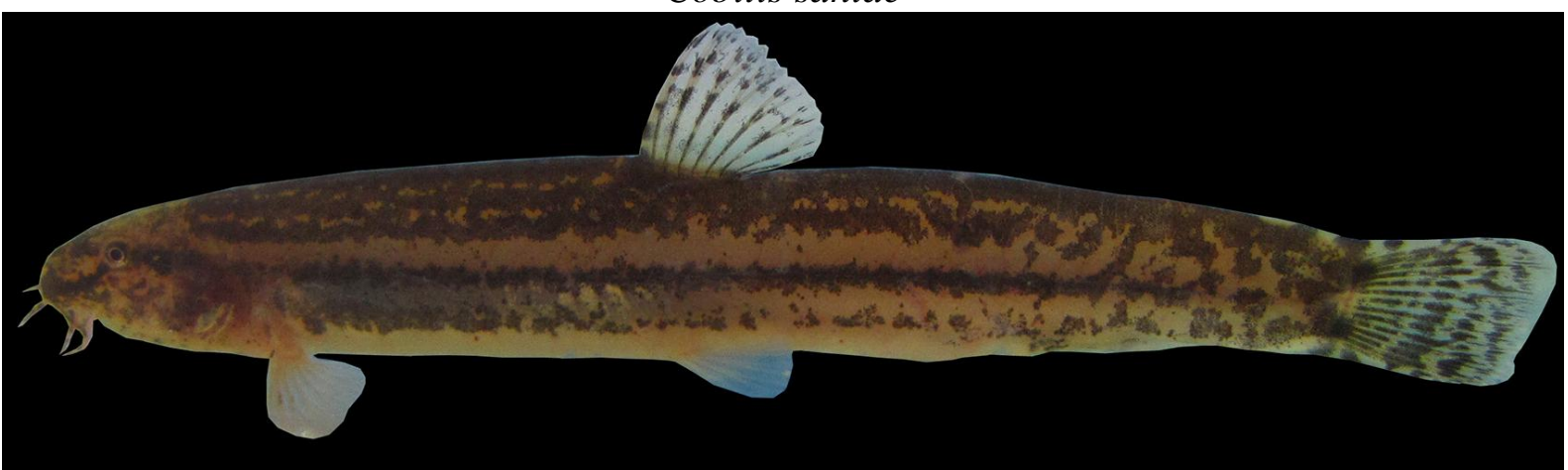

\section{Sabanejewia caspia}

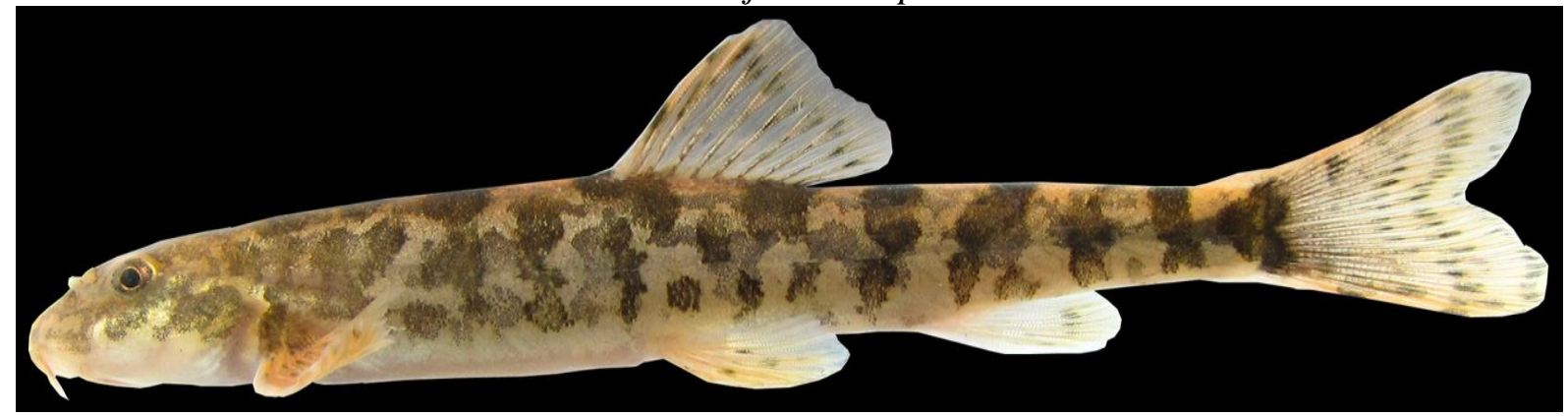

Oxynoemacheilus bergianus

......continued on the next page 


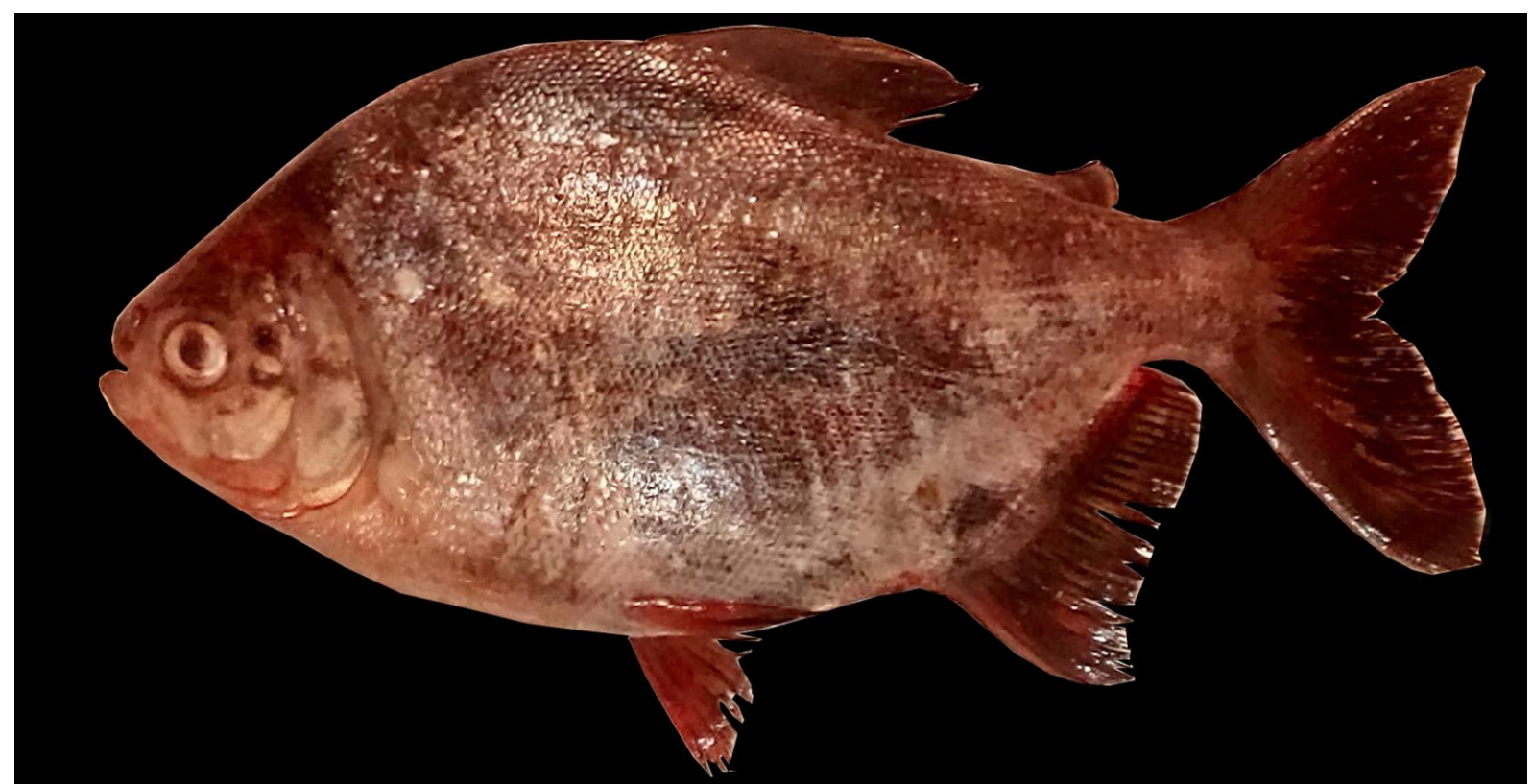

\section{Piaractus brachypomus}

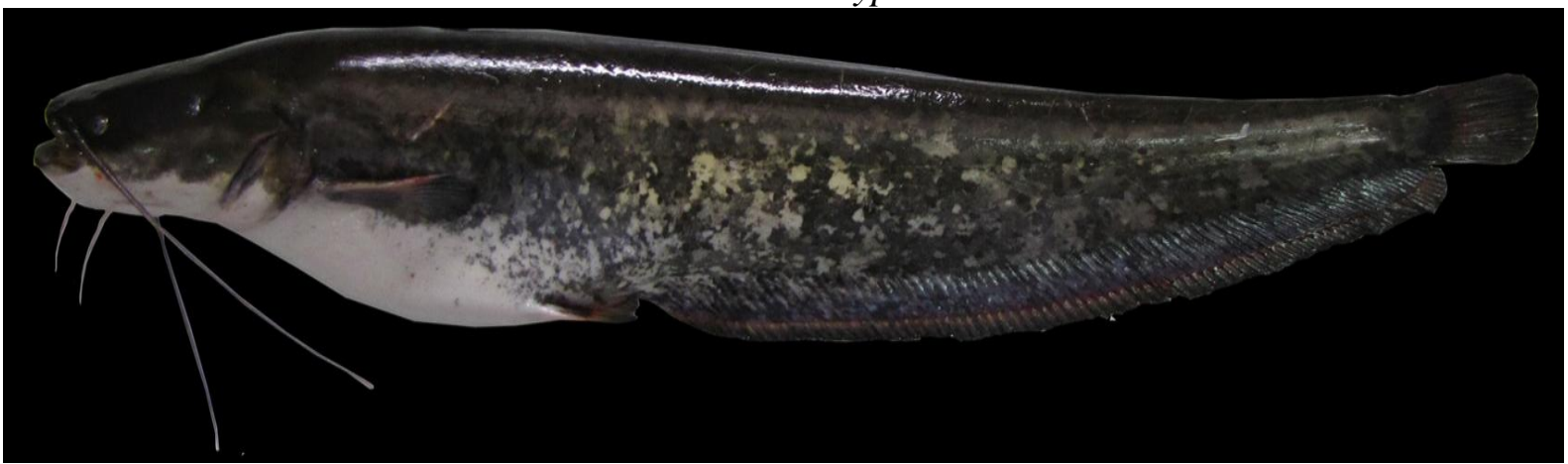

\section{Silurus glanis}

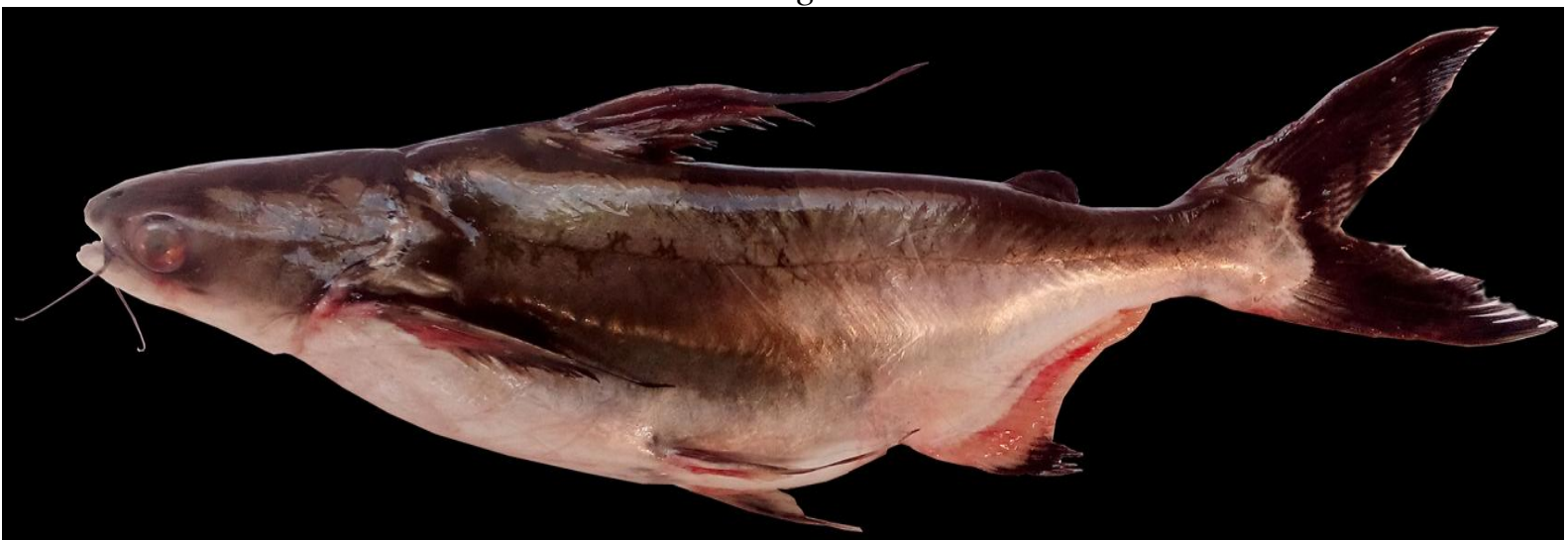

Pangasius sanitwongsei

......continued on the next page 


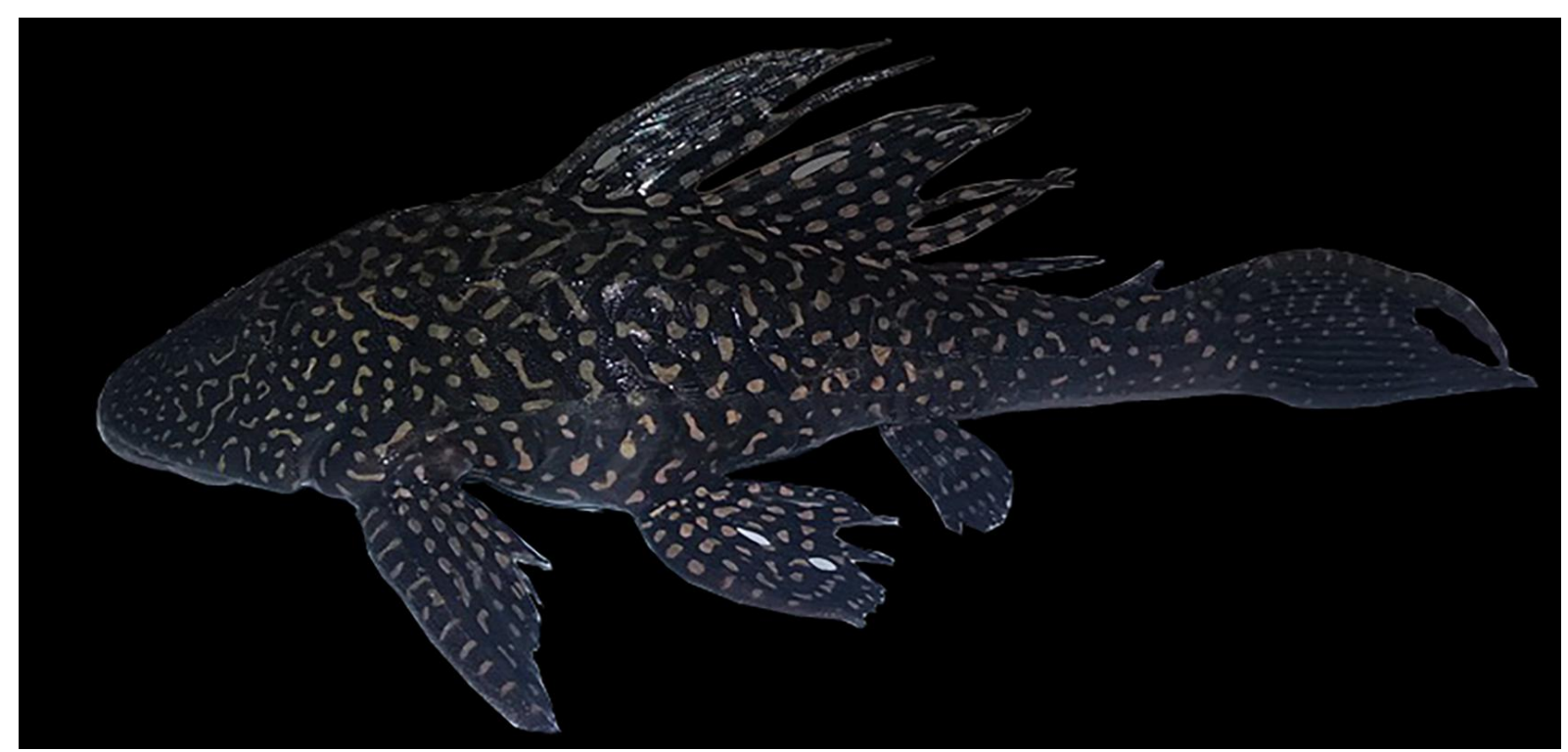

\section{Hypostomus plecostomus}

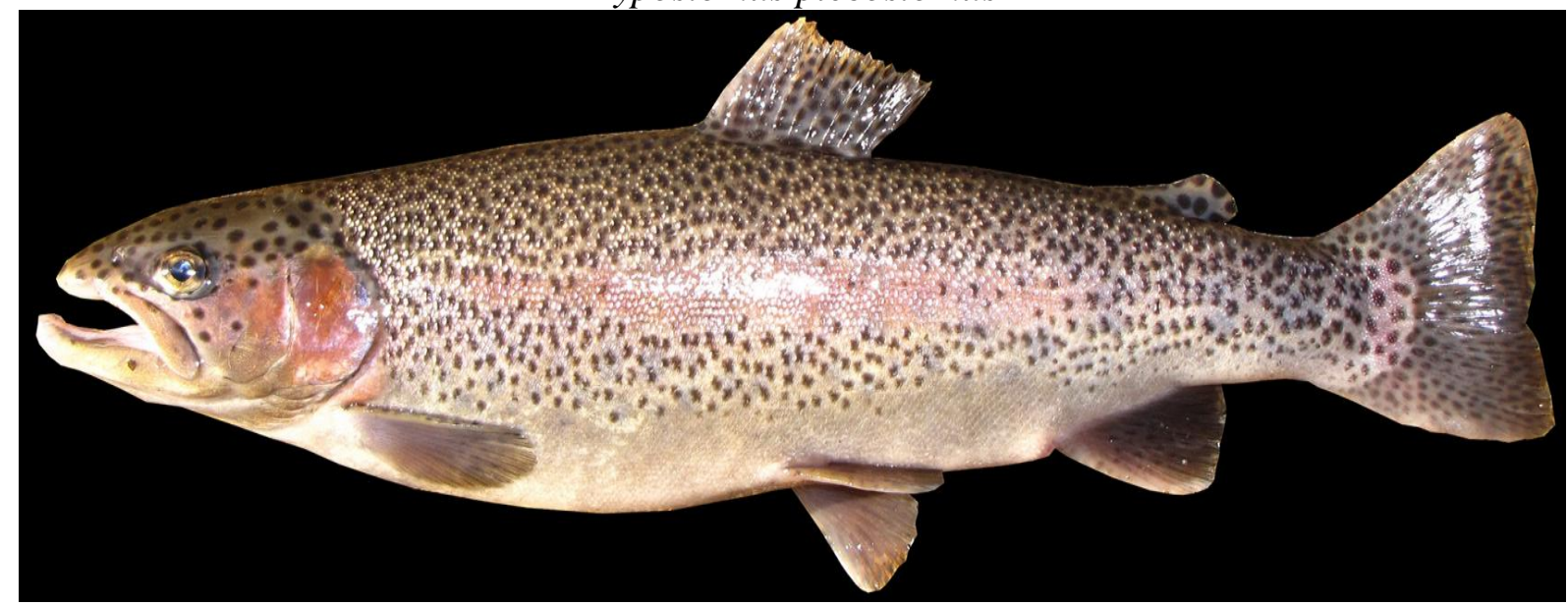

Oncorhynchus mykiss

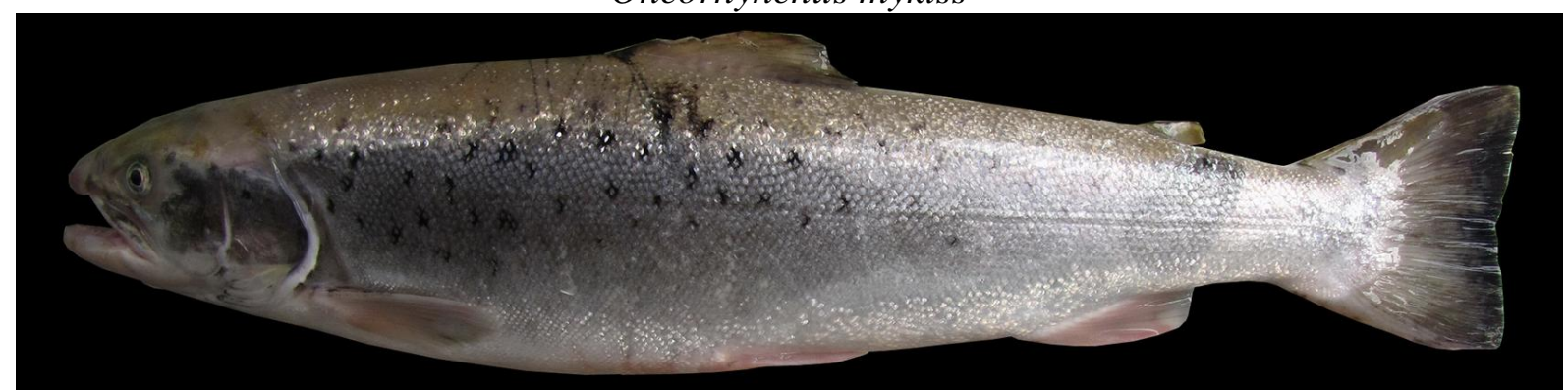

Salmo caspius

......continued on the next page 


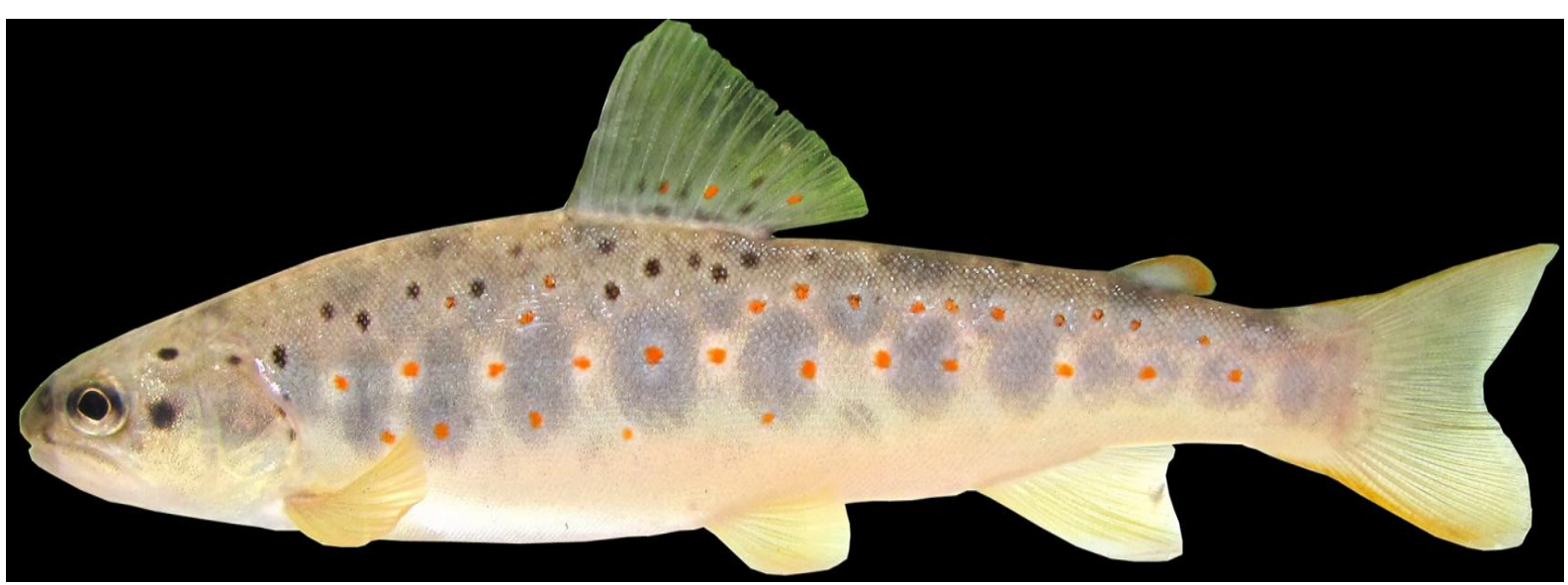

\section{Salmo trutta}

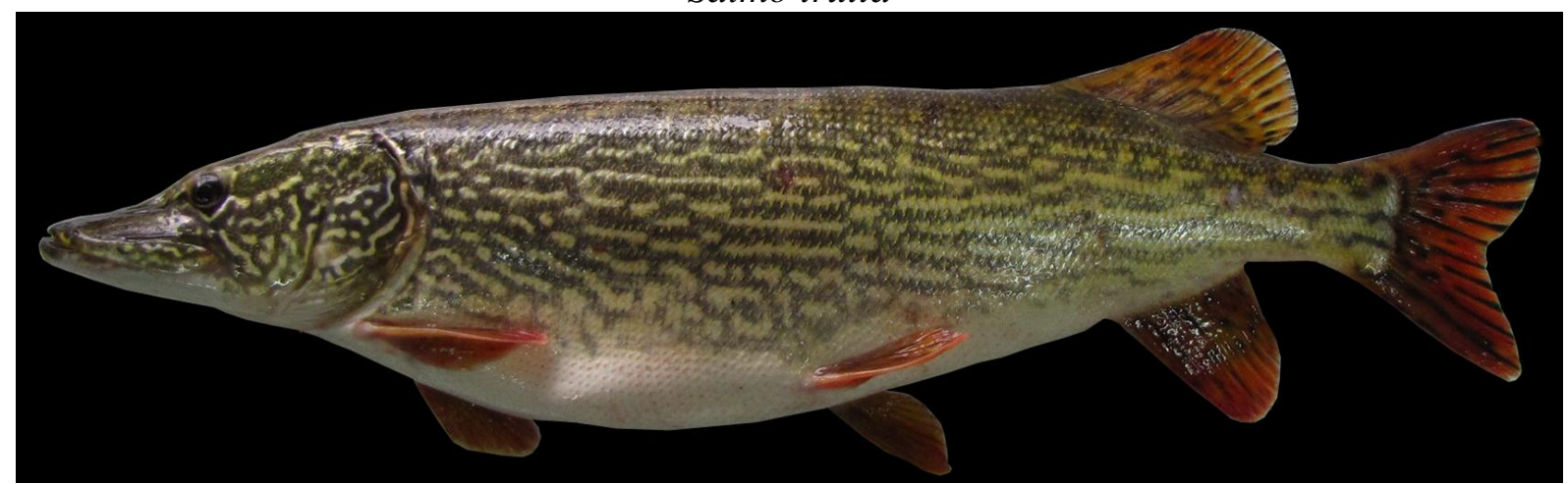

\section{Esox lucius}

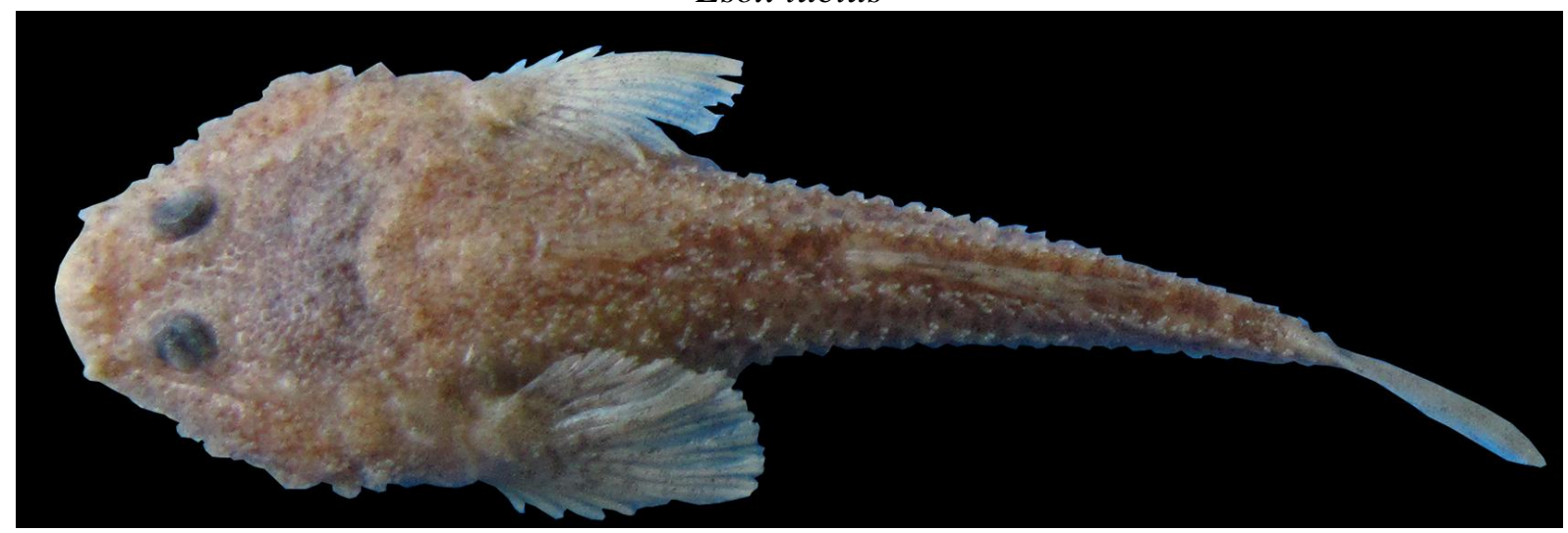

\section{Benthophilus ctenolepidus}

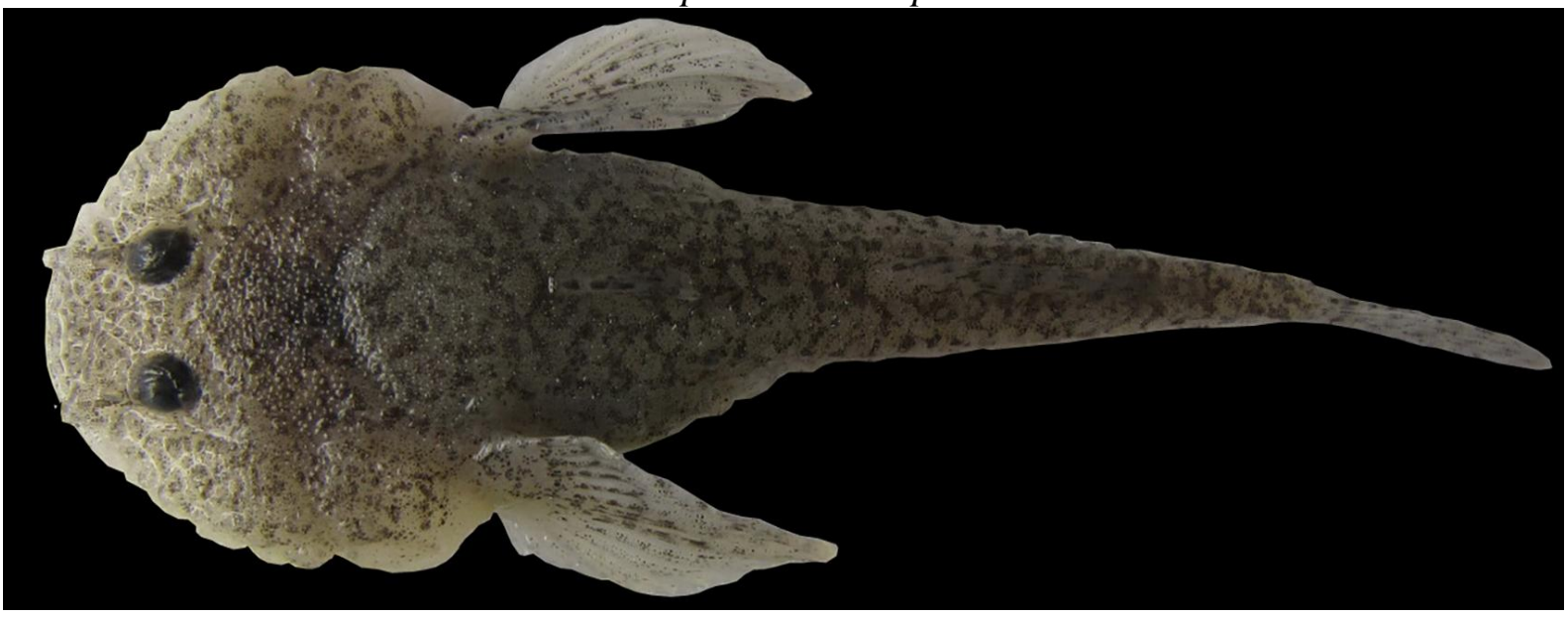

Benthophilus leobergius 

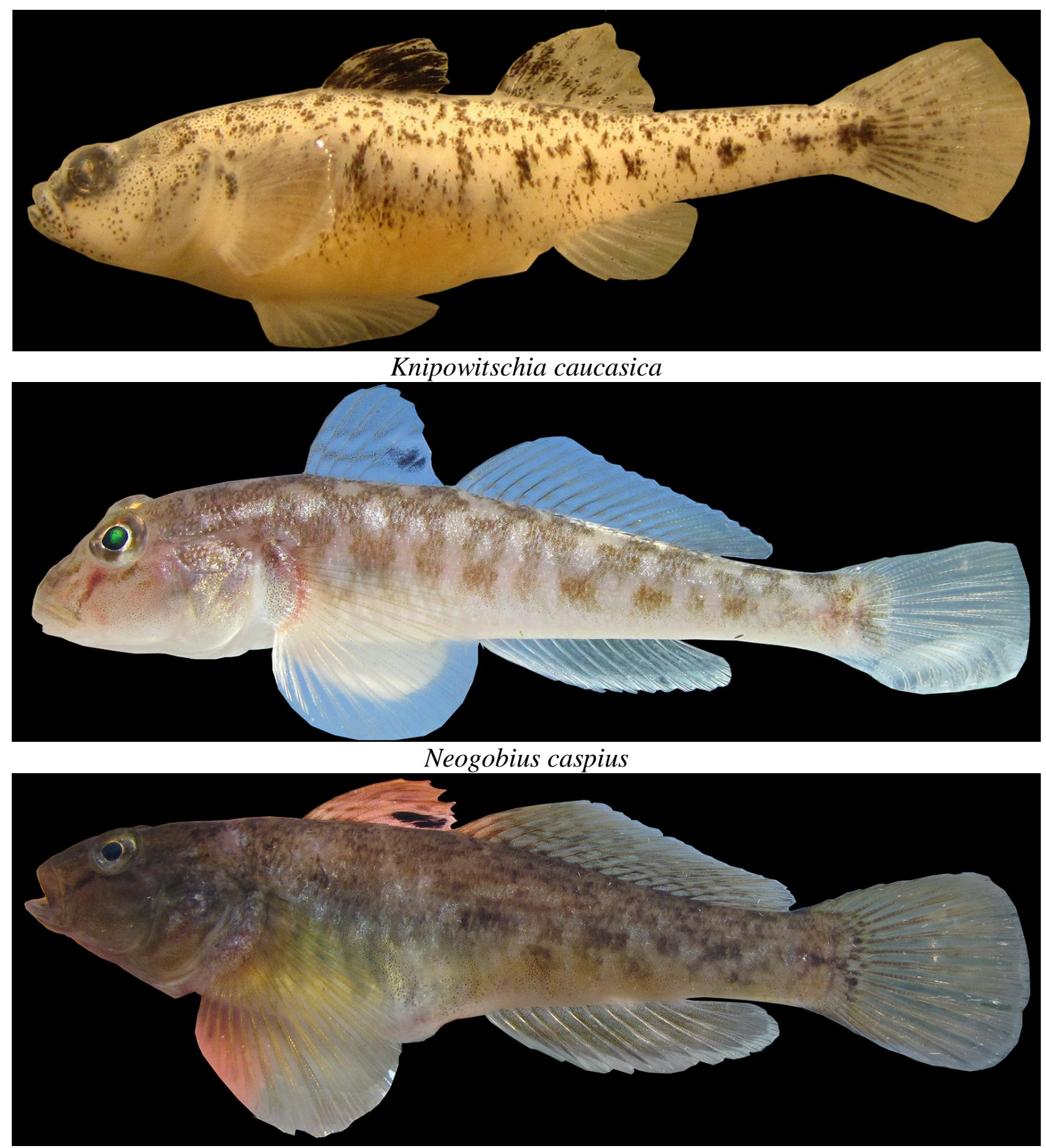

\section{Neogobius melanostomus}

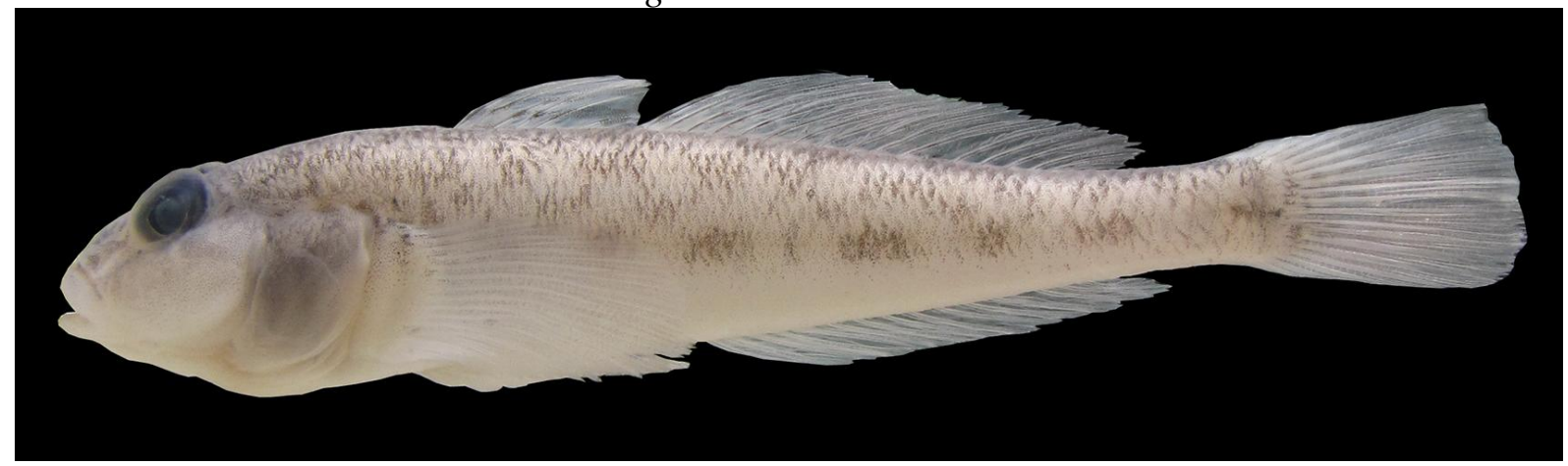

Neogobius pallasi

......continued on the next page 


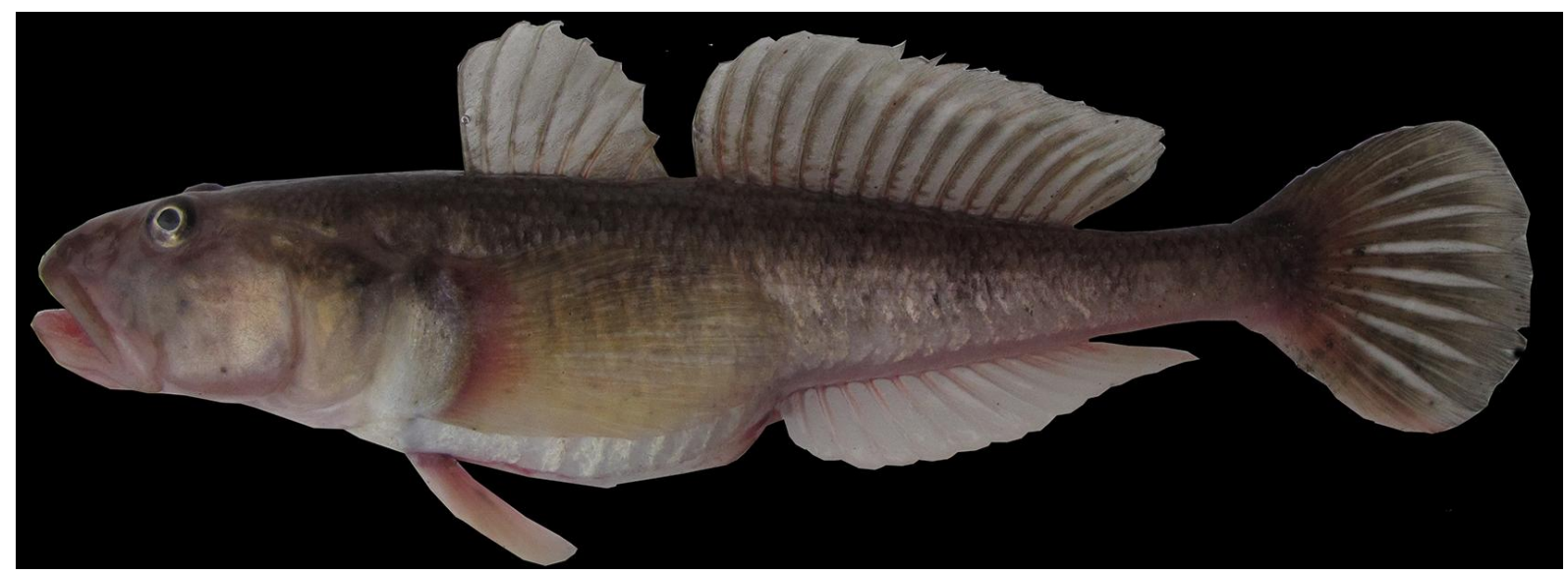

Ponticola bathybius

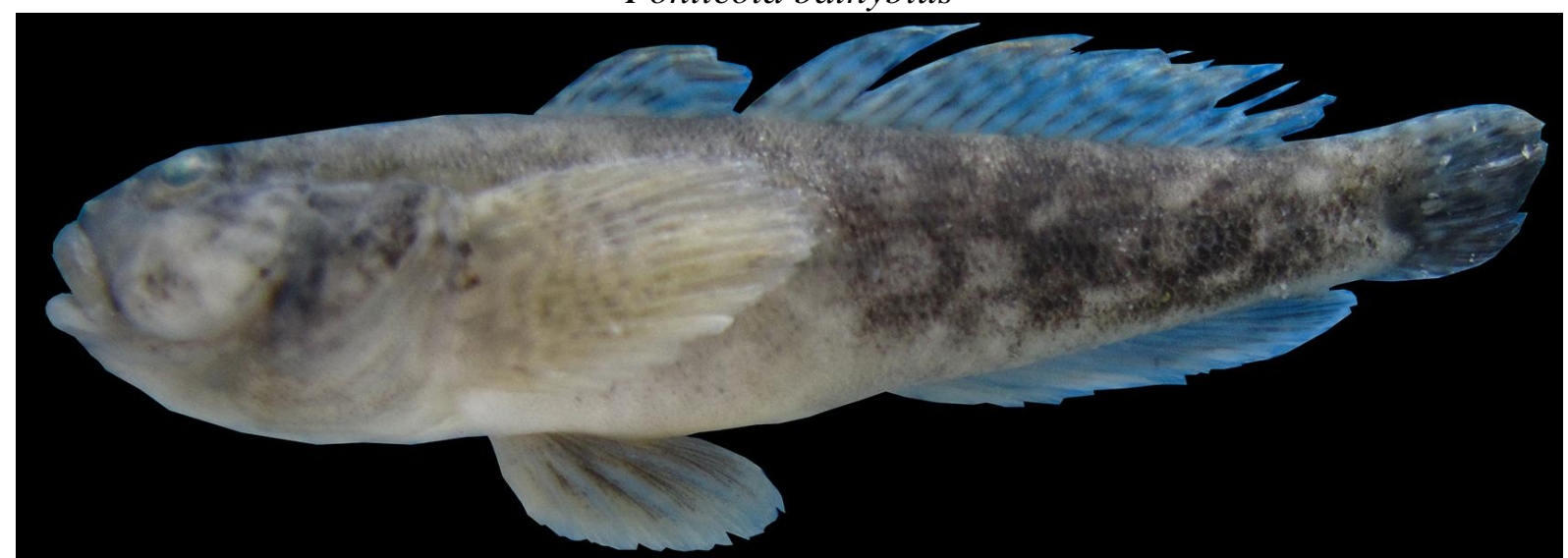

Ponticola goebeli

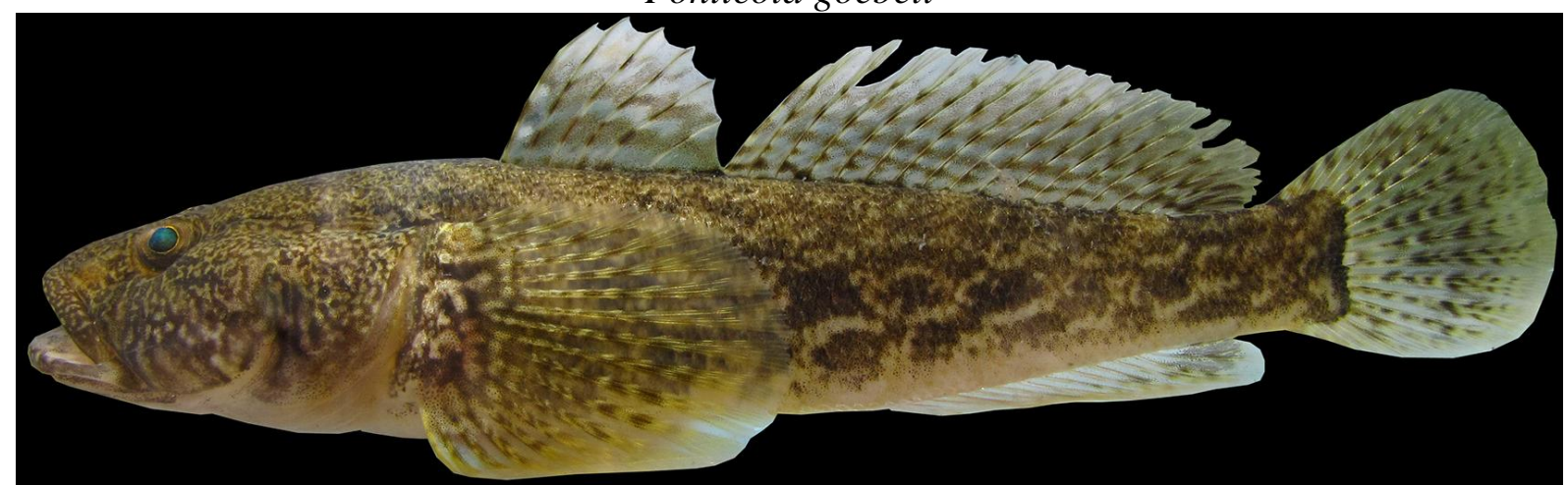

Ponticola gorlap

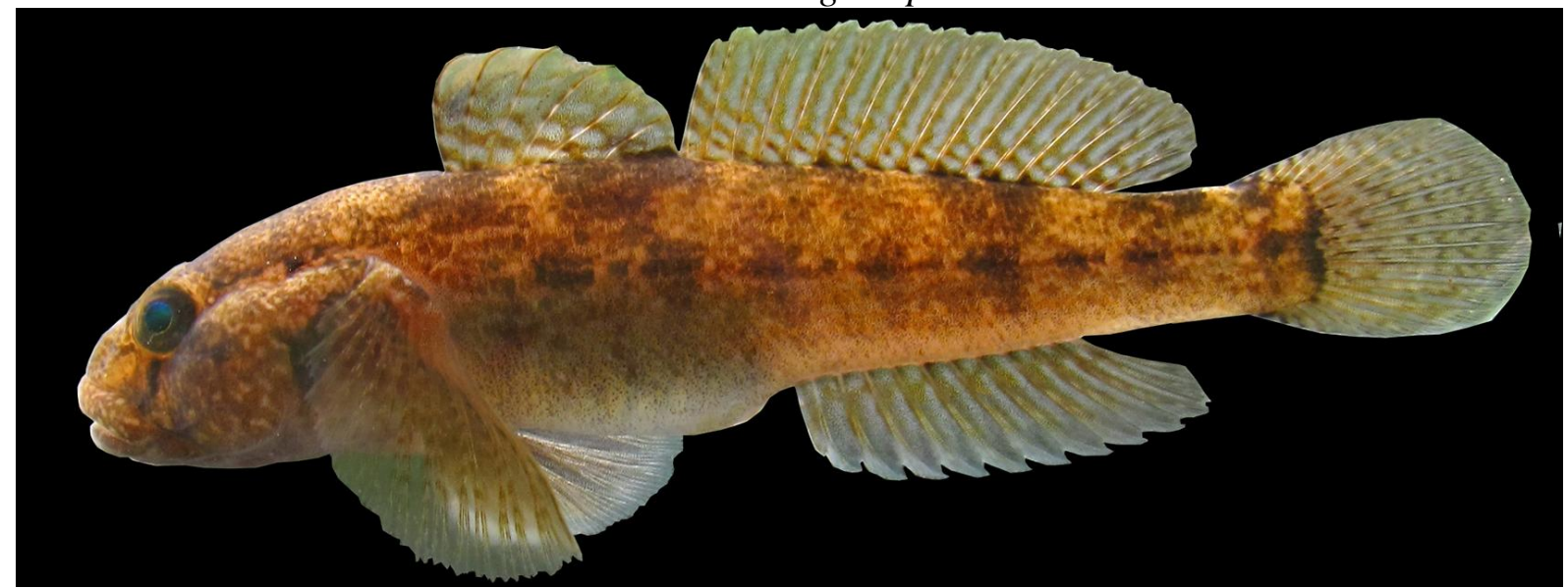

Ponticola iranicus

......continued on the next page 


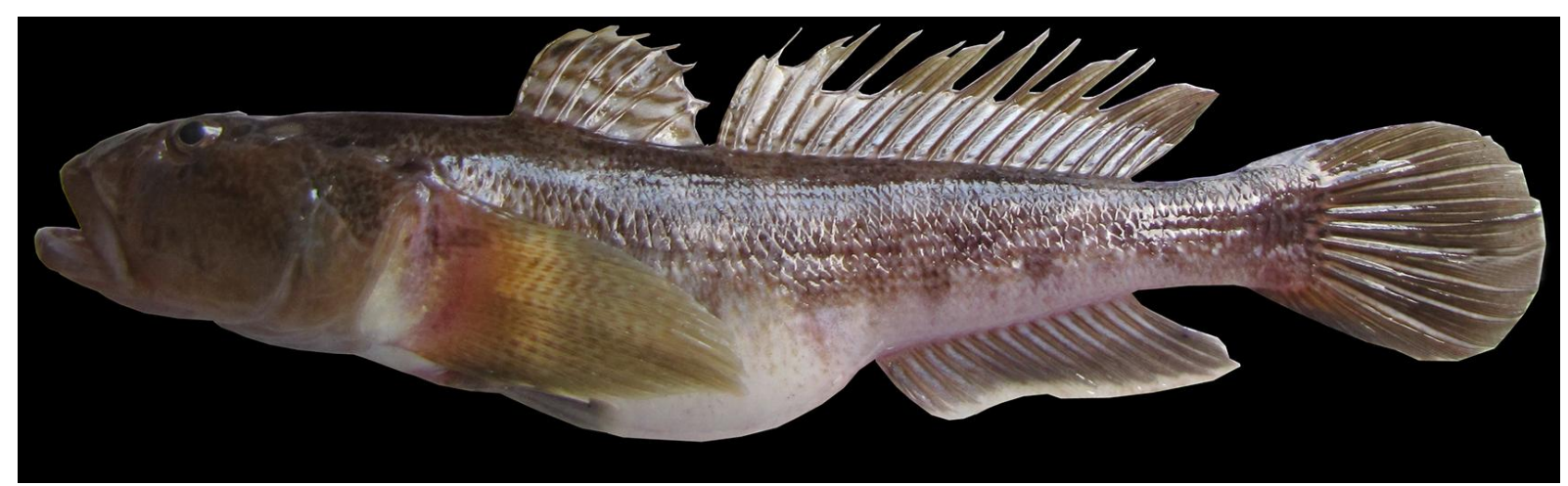

\section{Ponticola syrman}

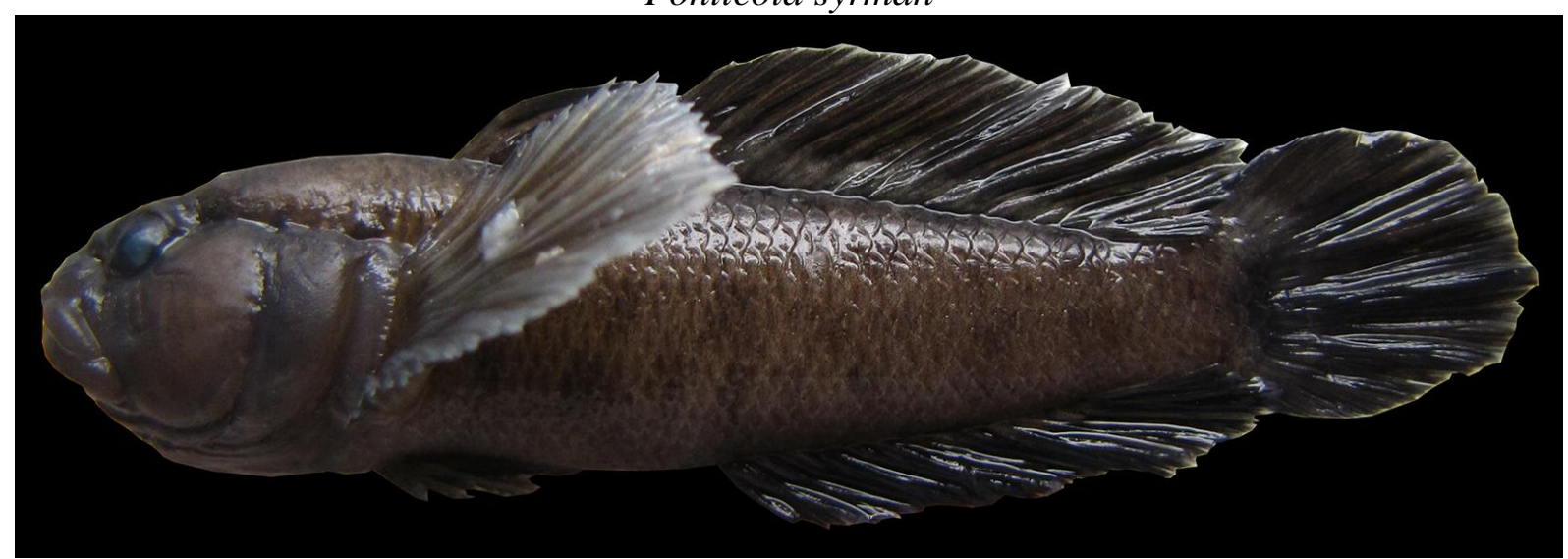

\section{Proterorhinus nasalis}

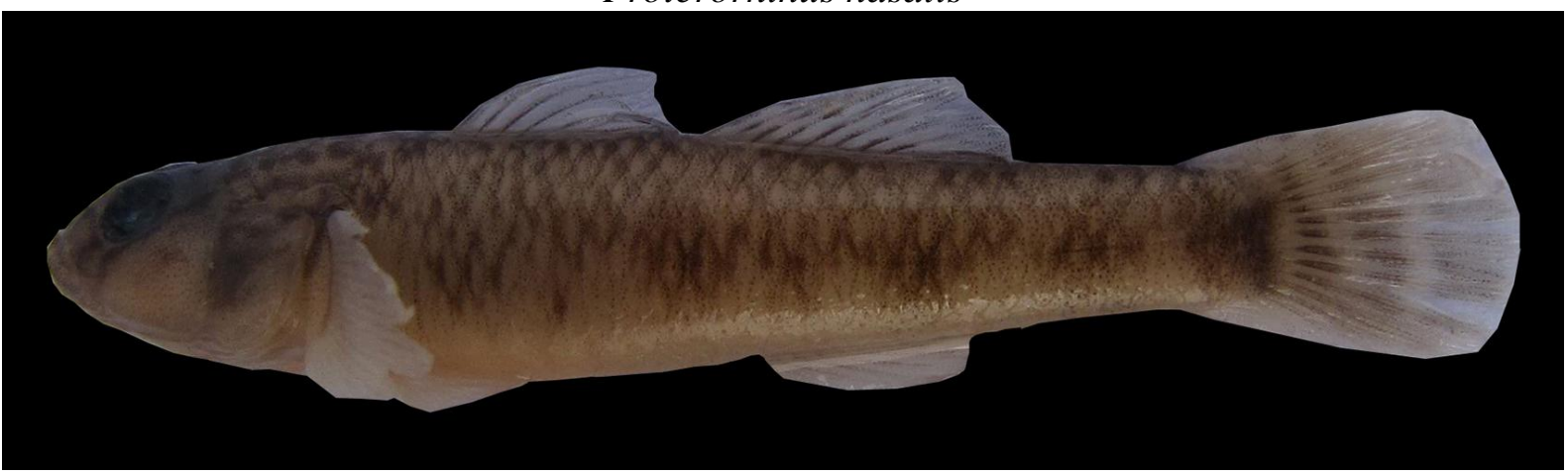

\section{Rhinogobius lindbergi}

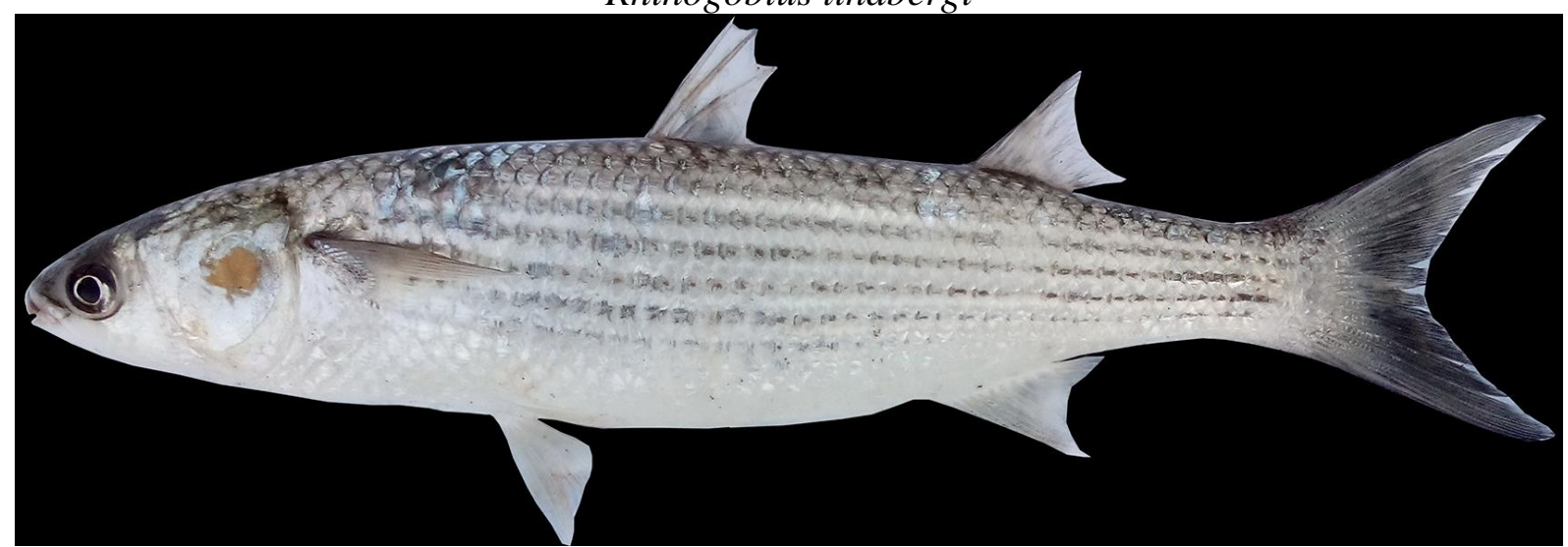

Chelon auratus

......continued on the next page 


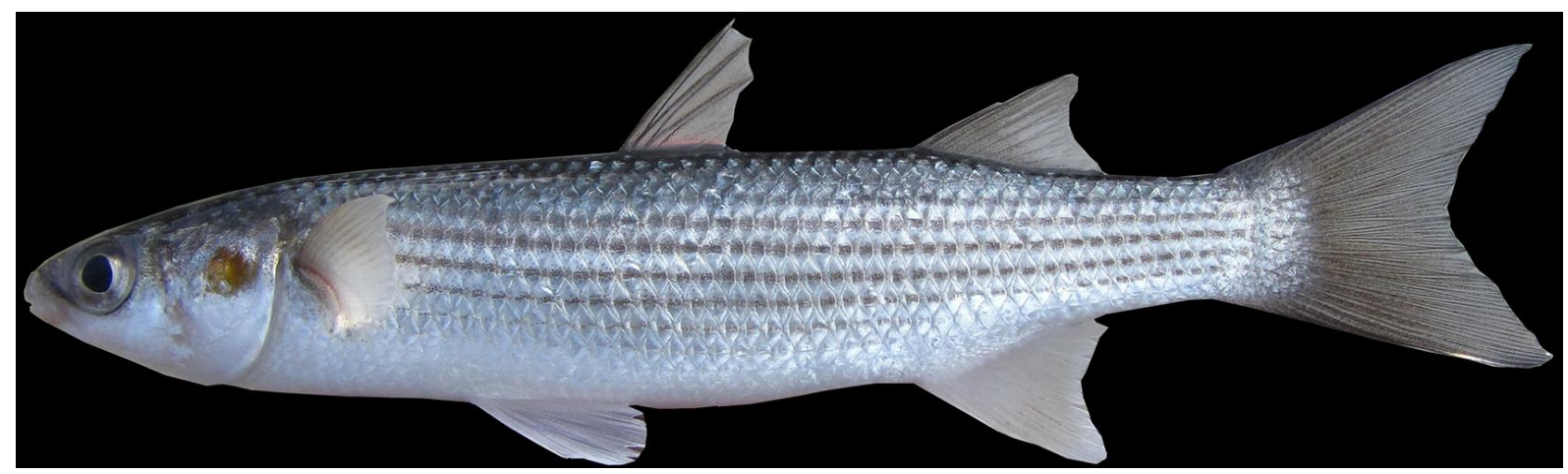

\section{Chelon saliens}

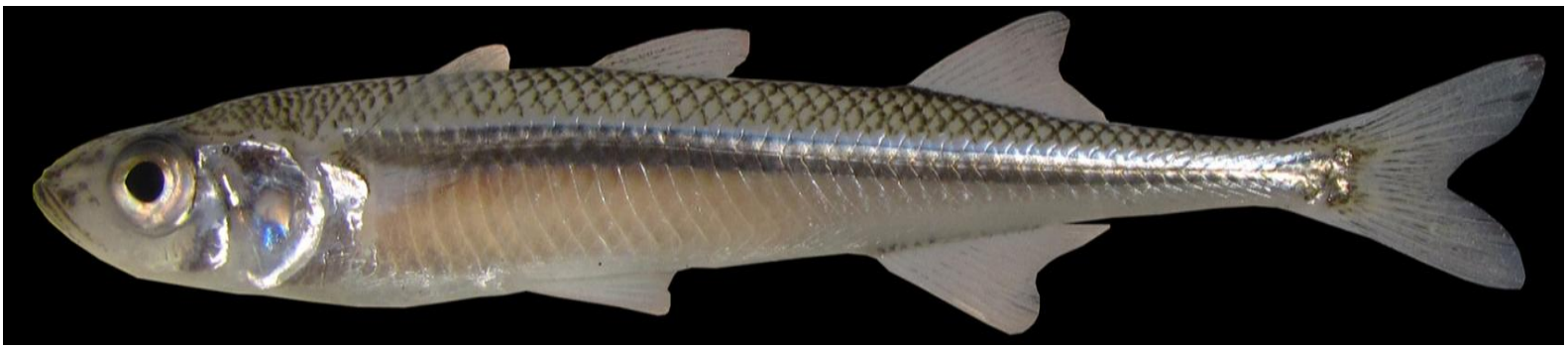

Atherina caspia

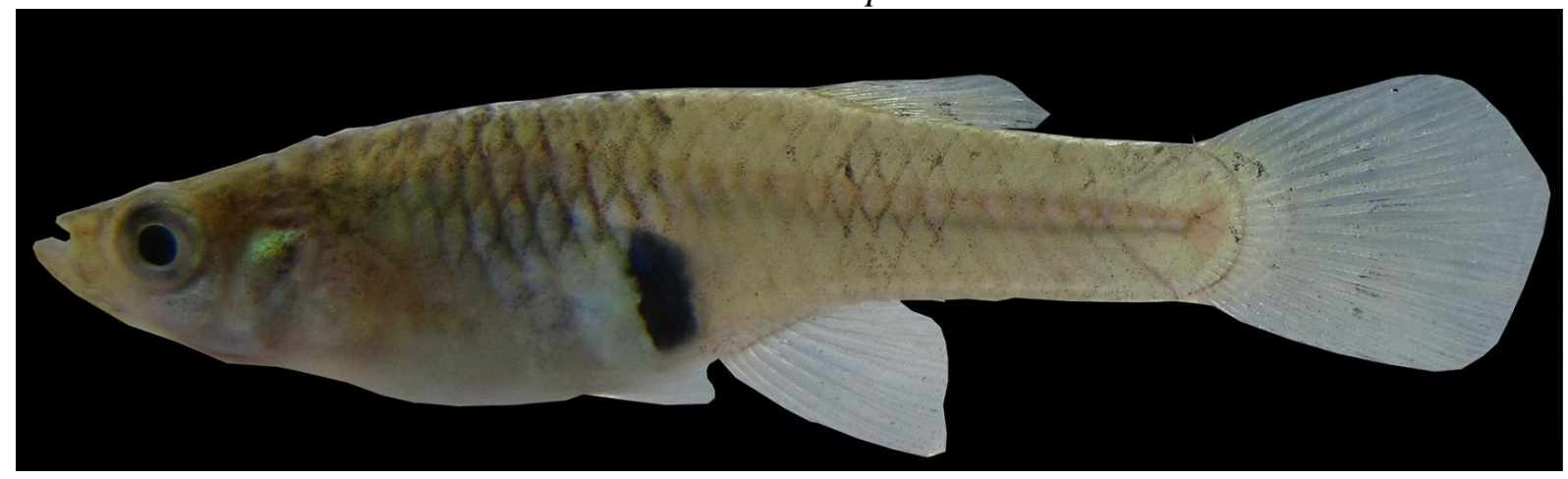

Gambusia holbrooki

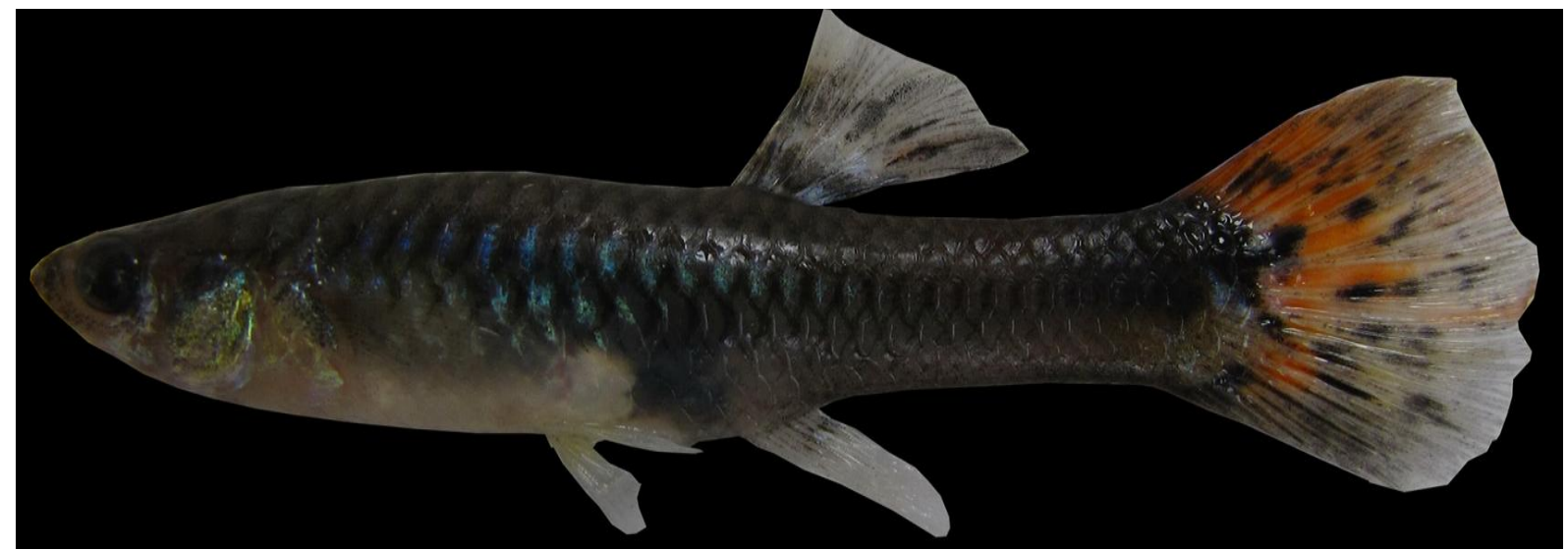

Poecilia reticulata

......continued on the next page 


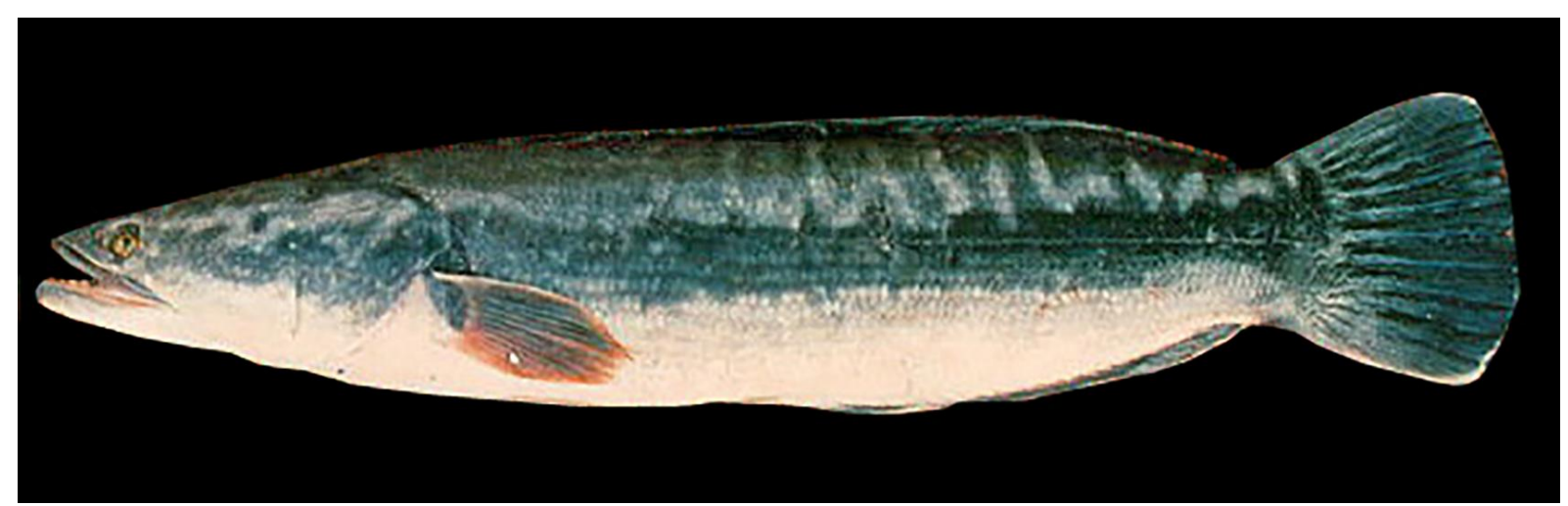

Channa micropeltes

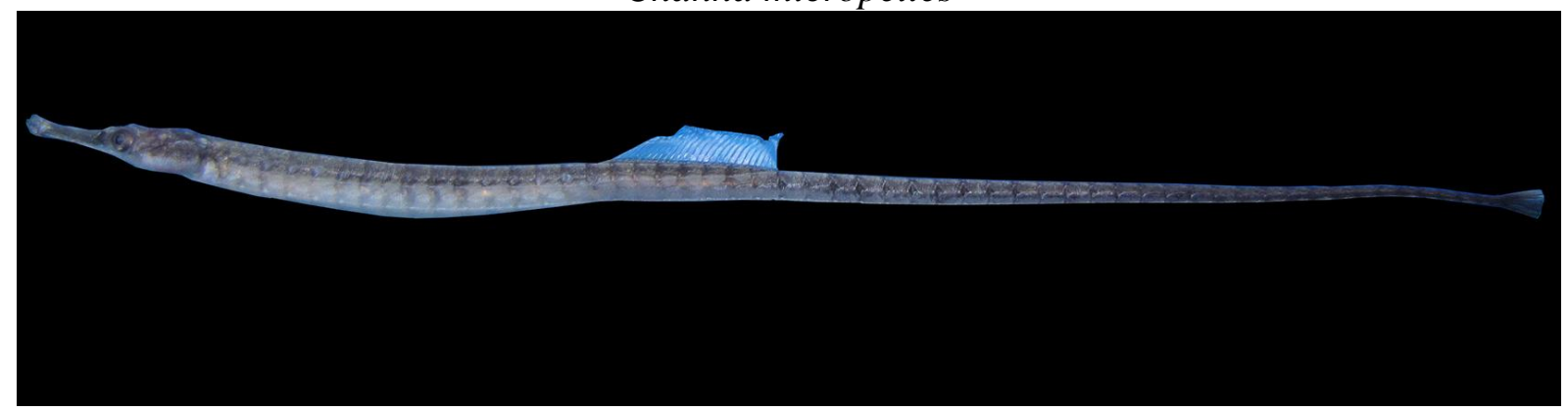

Syngnathus caspius

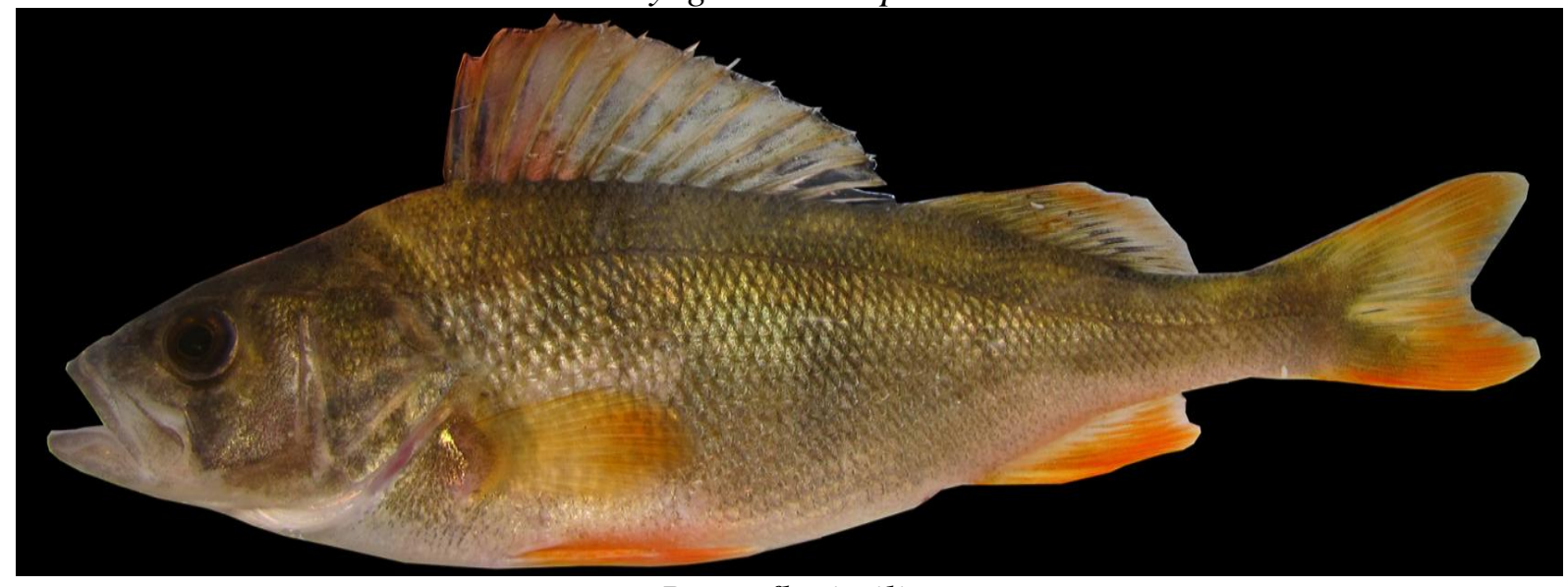

Perca fluviatilis

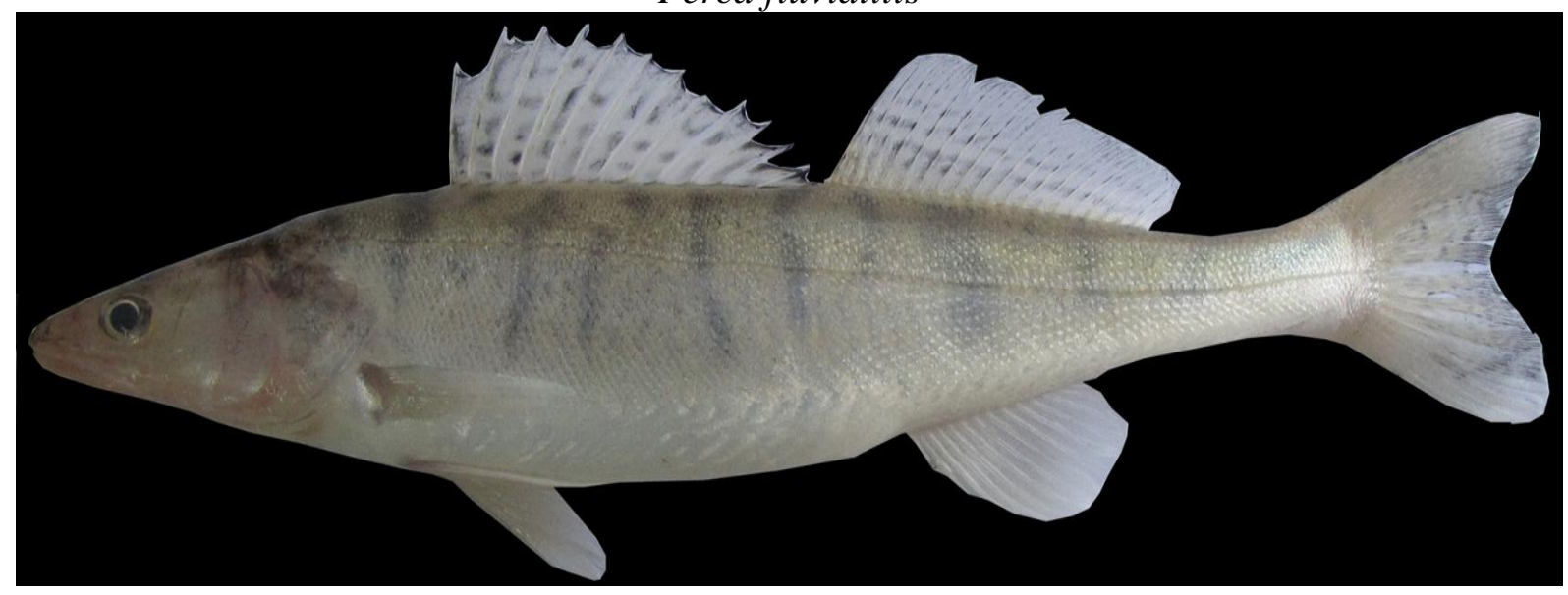

Sander lucioperca

......continued on the next page 


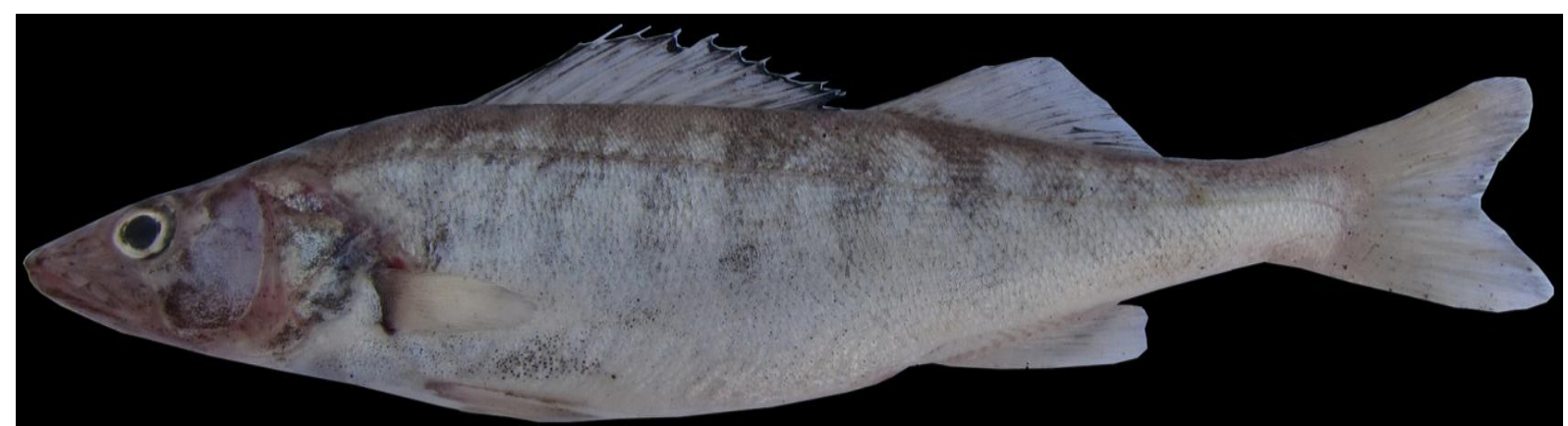

\section{Sander marinum}

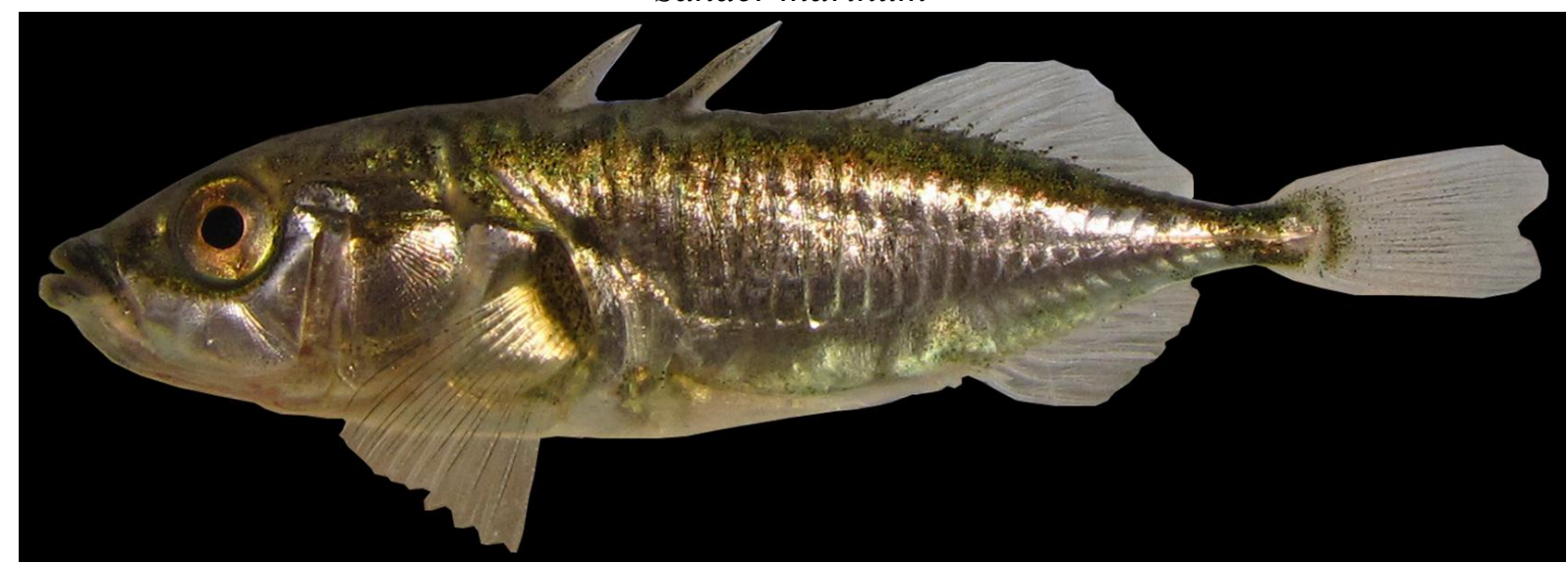

Gasterosteus aculeatus

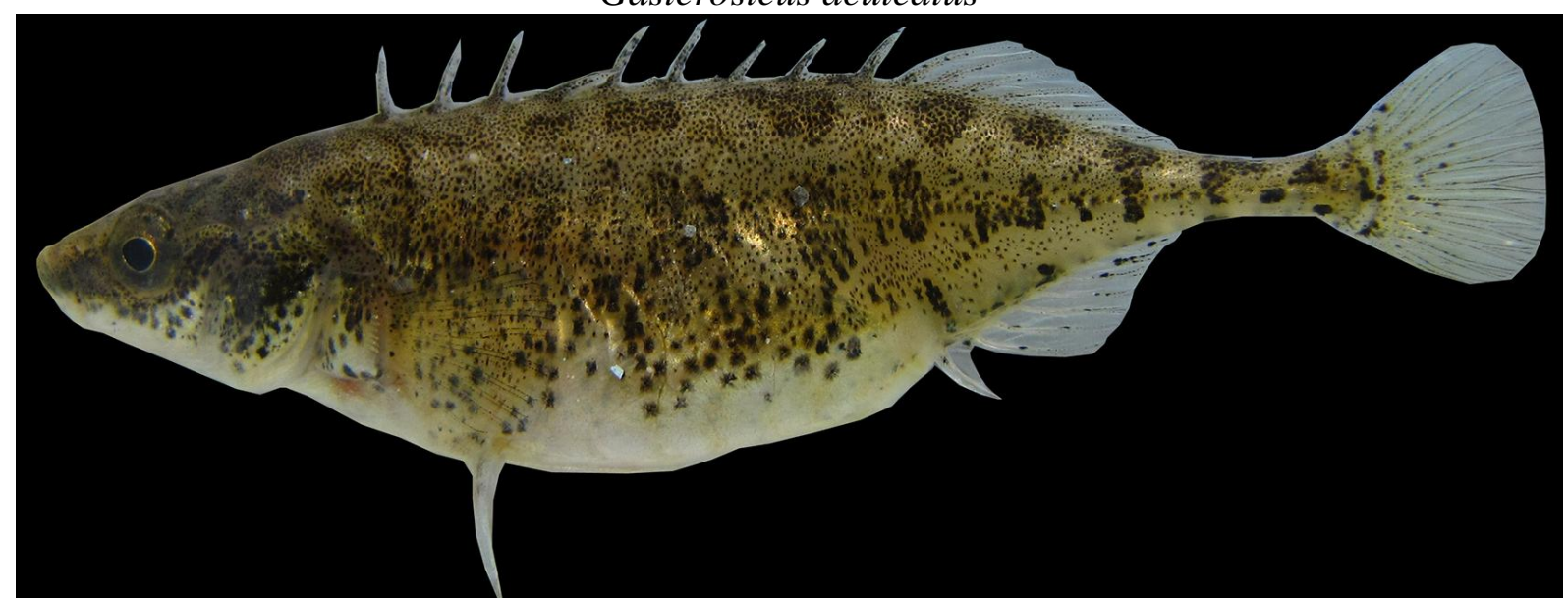

Pungitius platygaster 